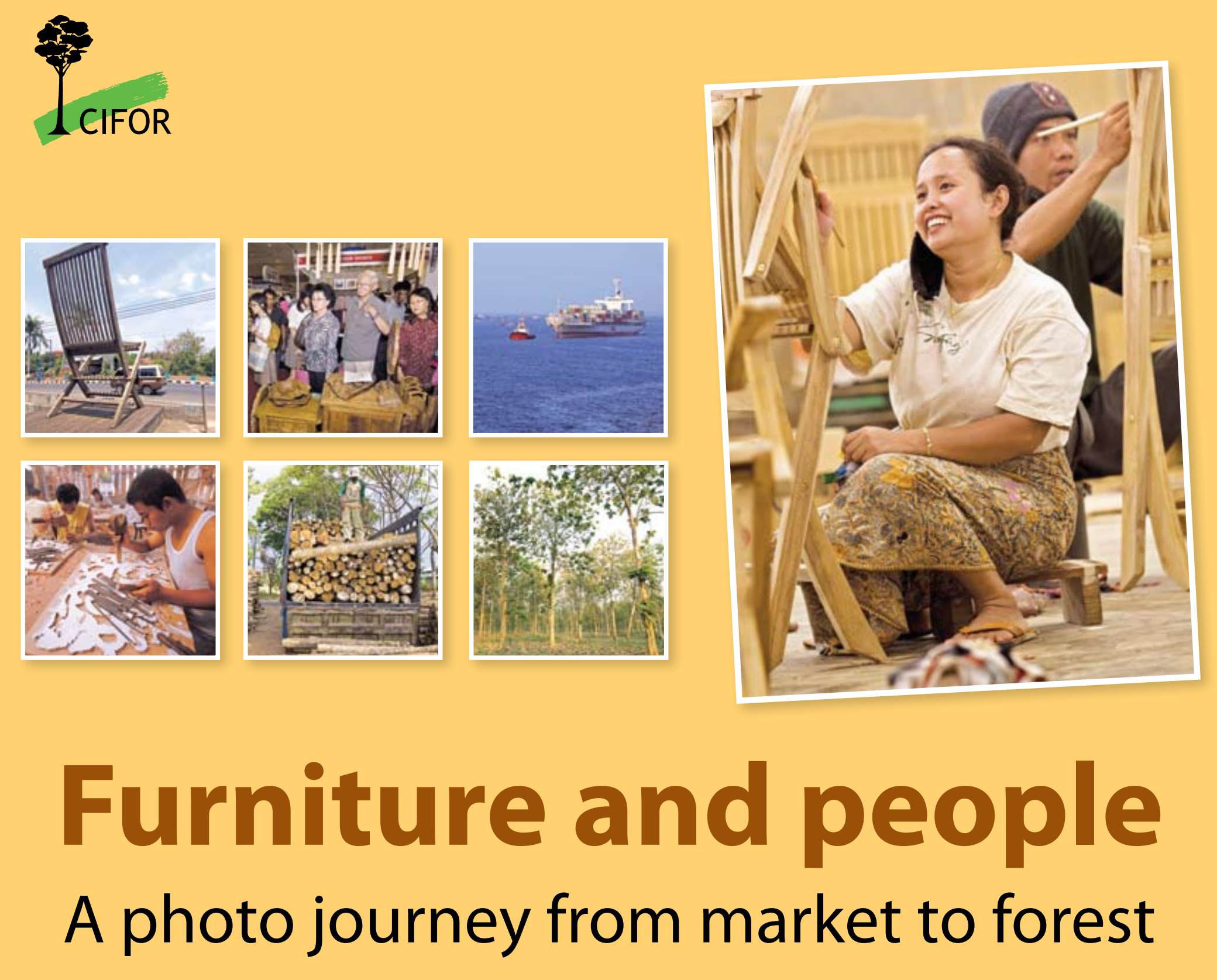

Herry Purnomo, Melati and Rika Harini Irawati 


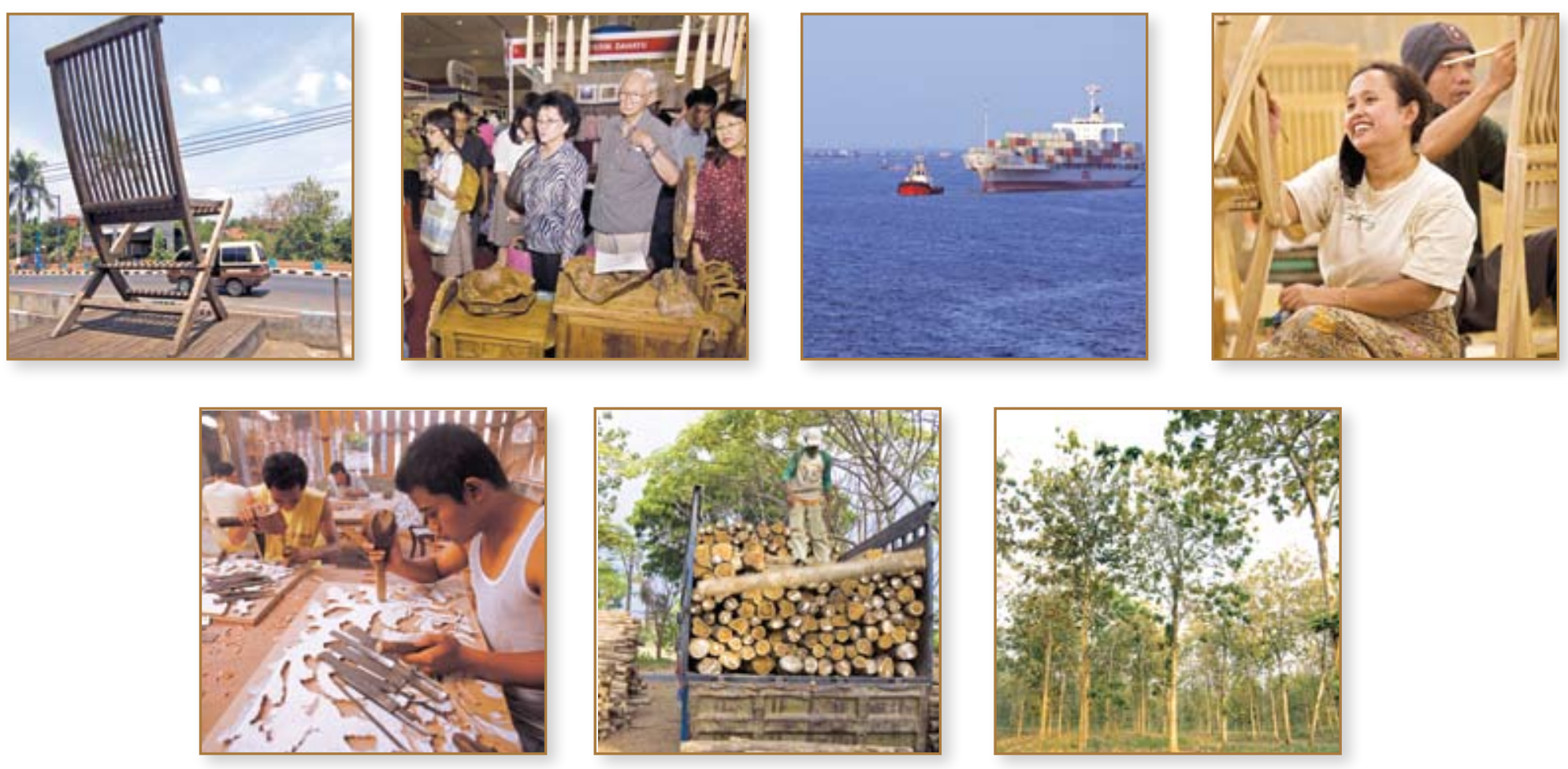

\section{Furniture and people A photo journey from market to forest}

Herry Purnomo, Melati and Rika Harini Irawati 
(C) 2009 by the Center for International Forestry Research. All rights reserved.

Printed in Indonesia

ISBN: 978-602-8693-06-6

Purnomo, H., Melati and Irawati, R.H. 2009 Furniture and people: A photo journey from market to forest. CIFOR, Bogor, Indonesia.

Photo credits: Taufik Istiqlal, Murdani Usman, Melati and Rika H. Irawati

Design and layout: Gun gun Rakayana

CIFOR

Jl. CIFOR, Situ Gede

Bogor Barat 16115

Indonesia

$\mathrm{T}+62(251) 8622-622$

$\mathrm{F}+62(251) 8622-100$

E cifor@cgiar.org

www.cifor.cgiar.org

Any views expressed in this book are those of the authors. They do not necessarily represent the views of CIFOR, the authors' institutions or the financial sponsors of this book.

\section{Center for International Forestry Research}

CIFOR advances human wellbeing, environmental conservation and equity by conducting research to inform policies and practices that affect forests in developing countries. CIFOR is one of 15 centres within the Consultative Group on International Agricultural Research (CGIAR). CIFOR's headquarters are in Bogor, Indonesia. It also has offices in Asia, Africa and South America. 


\section{Acknowledgement}

The authors of this book would like to thank James Clarke for his idea that initially started the making of this photo story book. We would also like to thank Edith Johnson who helped in text editing; Gun gun Rakayana, Eko Prianto and Gideon Suharyanto who helped with the layout, and also Ramadhani Achdiawan and Henny Linawati for their substantial input. Our thanks also goes out to the Jepara District Head, Hendro Martojo and government officials Salembayong, Djarot and Herry Purwanto for their invaluable support; Jati Widodo from Duta Jepara who kindly showed us the furniture production process at his factory; Koja Container Terminal, Tanjung Priok Customs Office, PT Pelindo II and CDC Banda Warehouse for providing access at the port of Tanjung Priok; Ahmad Fauzi, Achmad Zainudin, Karwadi and Bambang K. Kurniawan for their assistance in Jepara; as well as Akot Nurputro, Asrofi, Darwin, Muhamad Hatta, Margono, Sugiyanto, Nurhamid, Sholikin and Ali Anwar from the Jepara Small-scale Furniture Producers Association. Lastly, we would like to thank Taufik Istiqlal and Murdani Usman, without whose photography talents, we would never have completed this book with such high quality pictures.

The authors

Herry Purnomo, Melati and Rika Harini Irawati 


\section{Foreword}

This illustrated guide describes the different aspects of the furniture industry in Jepara affected by our furniture value chain project. The project aims to improve small-scale furniture enterprises that rely on mahogany and teak timber in Jepara by enhancing the structure and function of the furniture industry. Improved governance and efficiency can position small-scale producers in a greater role within the value chain, help their furniture enterprises thrive and enhance their income levels. The goals of the project are in line with UNDP's millennium development goals (MDGs) on poverty alleviation, global partnerships and environmental sustainability.

This guide tells the story of the furniture industry through photographs. Working backwards through the value chain, we start from the furniture buyers' markets, trace furniture back to furniture producers, then to timber trading and the forests where the timber comes from. 


\section{Contents}

Acknowledgement

Foreword

Contents

Chapter 1. Introduction

Chapter 2. Foreign and domestic markets

Chapter 3. Loading and shipping

Chapter 4. Exporters and big companies

Chapter 5. Small-scale producers and their associations

Chapter 6. Timber trading and sawmills

Chapter 7. Forests

Chapter 8. Key messages 



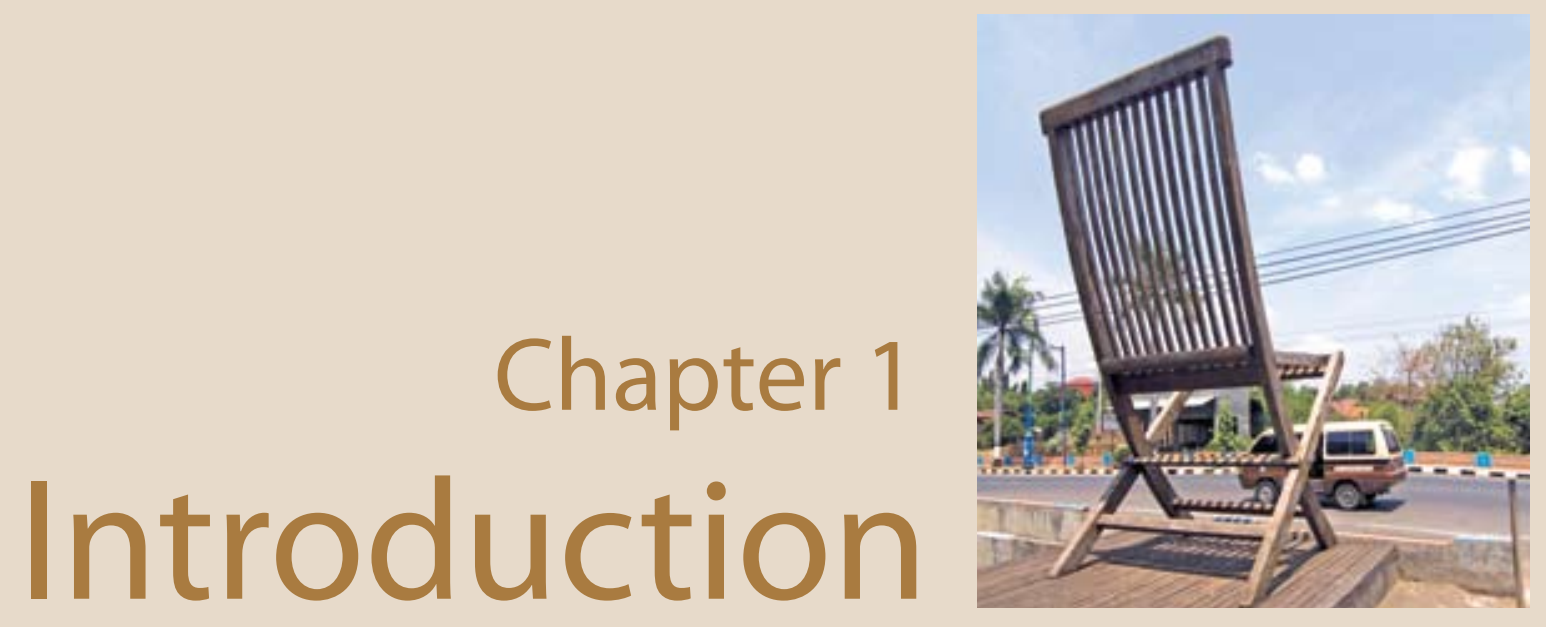




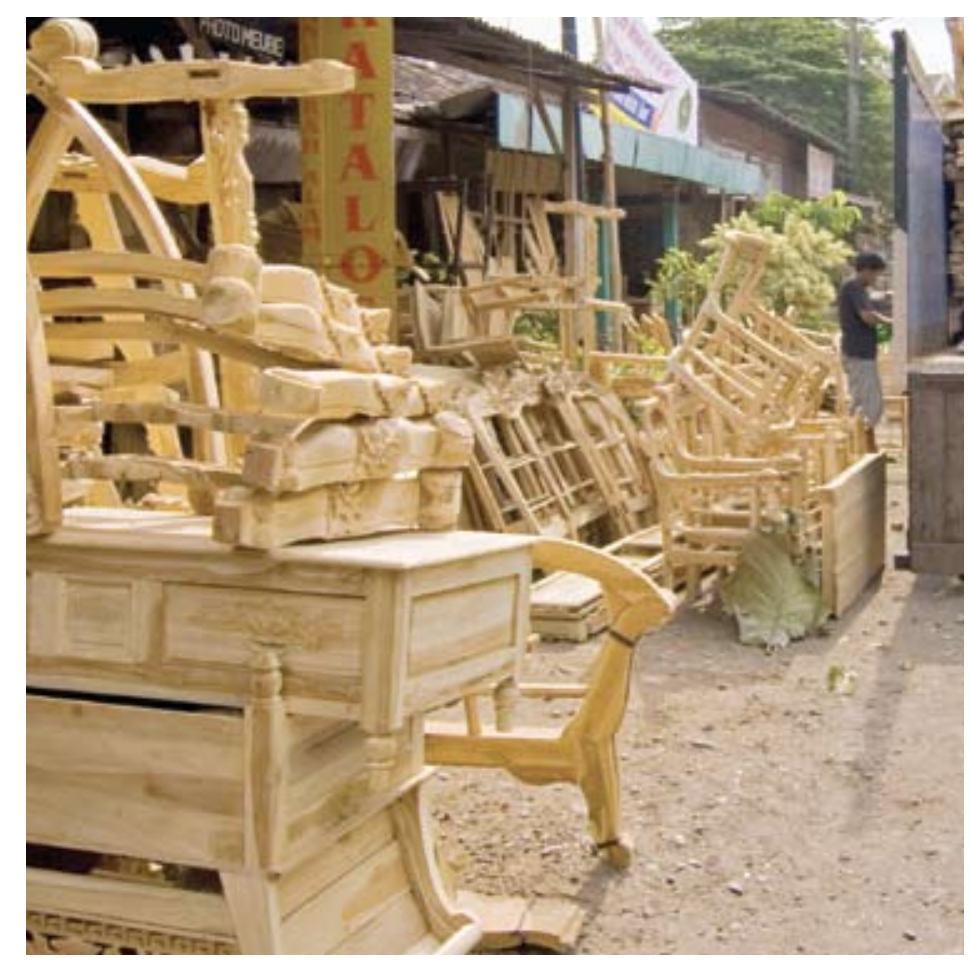

\section{Introduction}

The use of teak in furniture making has long been a part of Javanese culture. Centuries of historical records dating back to the seventh century BCE describe the abundance of teak forests in Central Java and the formation of skilled carpentry groups who used its timber for the Kalingga, Majapahit, Demak and Mataram kingdoms. The Javanese consider teak and items made from teak a valuable part of their culture, a species apart from other types of wood. Local carvers and furniture makers absorbed the influences of Chinese, Indian, Arabic and European designers, producing to this day 
intricate designs and highly sought after furniture. The seventeenth century port city of Jepara, once a bustling centre of maritime commerce, remains today a major centre of furniture production in Central Java.

The Indonesian furniture industry faces challenges as it struggles to secure its place in competitive global markets. Business relations between furniture producers and their buyers are usually unbalanced; buyers set the price and producers cannot negotiate a better deal. These unfair relations are part of the legacy from Javanese court practices. Patron-client relationships among members of the Javanese royal household and their subservient carpenters have defined that imbalance since the seventh century when Queen Shima instructed her skilled workers to create specific furniture and art designs for her palace with no compensation. In 1700, Queen Kalinyamat encouraged her woodworkers to produce high quality furniture for international trade, as did the Indonesian heroine, Kartini in 1800, who helped promote their work to Europeans with whom she corresponded. Patrons supported woodworkers by instructing product designs, opening access to markets, and ensuring steady orders. Their role was often considered as 'godly', highly honoured and never questioned. These patron-client relationships are still present in modern day relationships between buyers and Indonesian furniture producers, which we will discuss later on.

The Furniture Value Chain project is currently assessing opportunities for improving the added value of Indonesian furniture products which, in turn, will improve the livelihoods of millions of people involved in the industry, despite the current gloom in the furniture industry. Indonesians can build on their comparative advantages to mark their specific strengths on the international and domestic market.

'Furniture value chain' describes the series of activities required to bring a product or service from conception or design, through different phases of production, to delivery to final consumers 
and disposal after use. The value chain applies a systemic lense on a particular product. This bigger picture helps explain at what points in the chain value is added, and helps analyse where those participating in it can boost their income. Good value chain governance ensures that interactions between enterprises and firms along the value chain are efficient and effective. Power asymmetries among various actors is central to value chain governance.

There are four types of value chain governance.

- The market governs whenever there are many customers and many suppliers and repeat transactions are possible. In market governance information flow is limited and no technical assistance is available.

- In a balanced network suppliers have various customers; information flows freely in both directions, and both sides can and do solve problems through negotiation.

- A directed network is indicated by a main customer who buys at least $50 \%$ of a supplier's output; the customer defines the product and provides technical assistance, and information is unbalanced

- A hierarchy governs whenever there is vertical integration; supplier enterprises are owned by the buyers so they have very limited decision-making authority.

The Jepara furniture value chain connects producers from Jepara District with furniture retailers abroad (Figure 1). The governance type between finishing companies and small-scale producers is a hierarchy. The global buyers are subsidiaries of the overseas retailers. Few finishing companies develop their own designs. They are protective of their designs and try to prevent others from imitating them for mass production. For their part, the exporters are driven by the foreign importers and global brokers, who are in a directed network system with international retailers. 
Figure 1.

Jepara value chain

governance
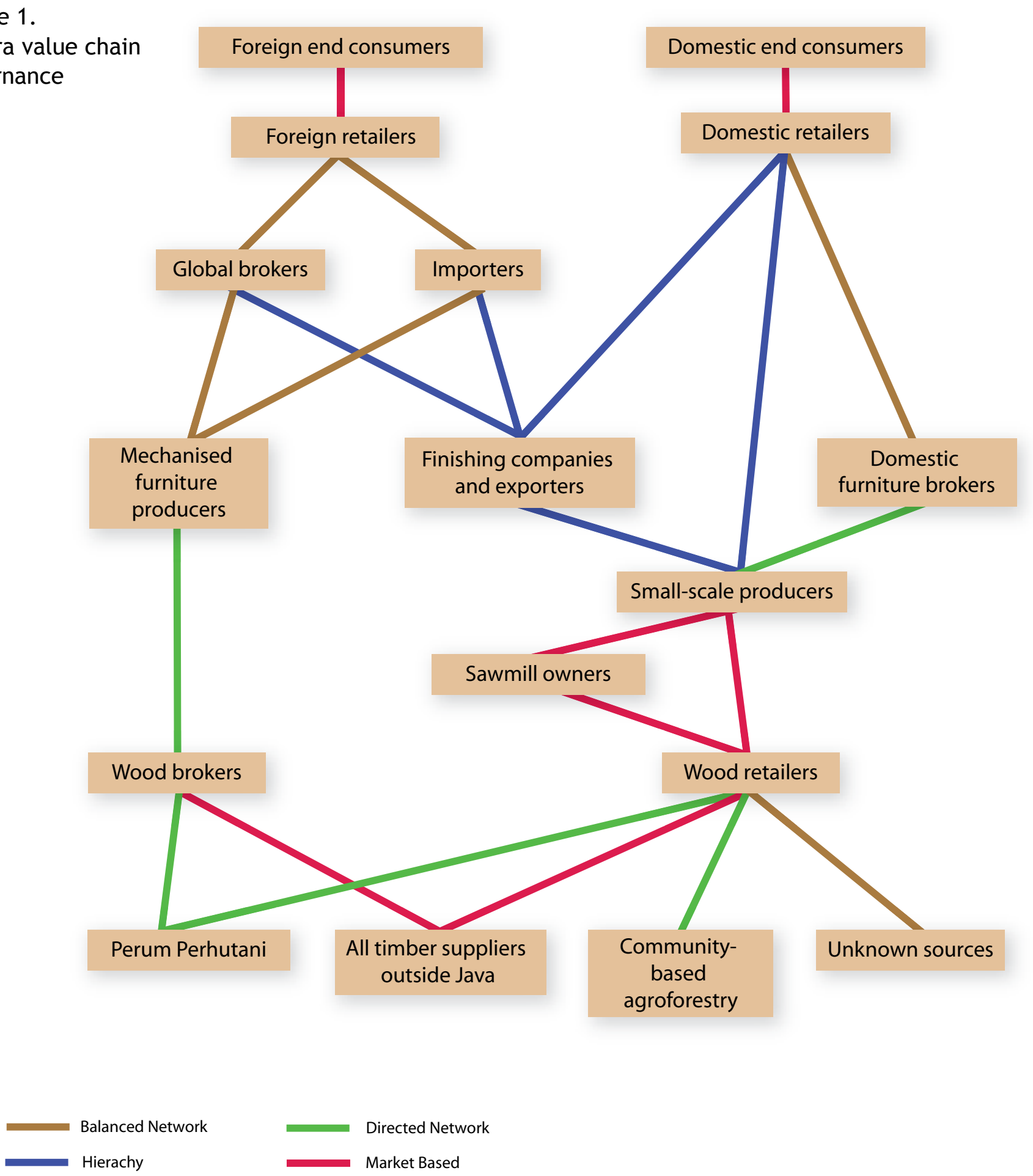

Furniture and people: A photo journey from market to forest 
The small-scale producers are in a directed network relationship with domestic brokers. The brokers are the main customers of the small-scale producers and take more than $50 \%$ of their products. The brokers can easily shift from one producer to another. Governance by a directed network is also dominant between exporters and small-scale producers. In some situations, the relationship has become a hierarchy when exporters have exercised more control over small-scale producers. Few small-scale producers have their own showrooms. Mechanised furniture producers have a better position in the value chain. They are in a balanced network relationship with their buyers, the global brokers and importers. 


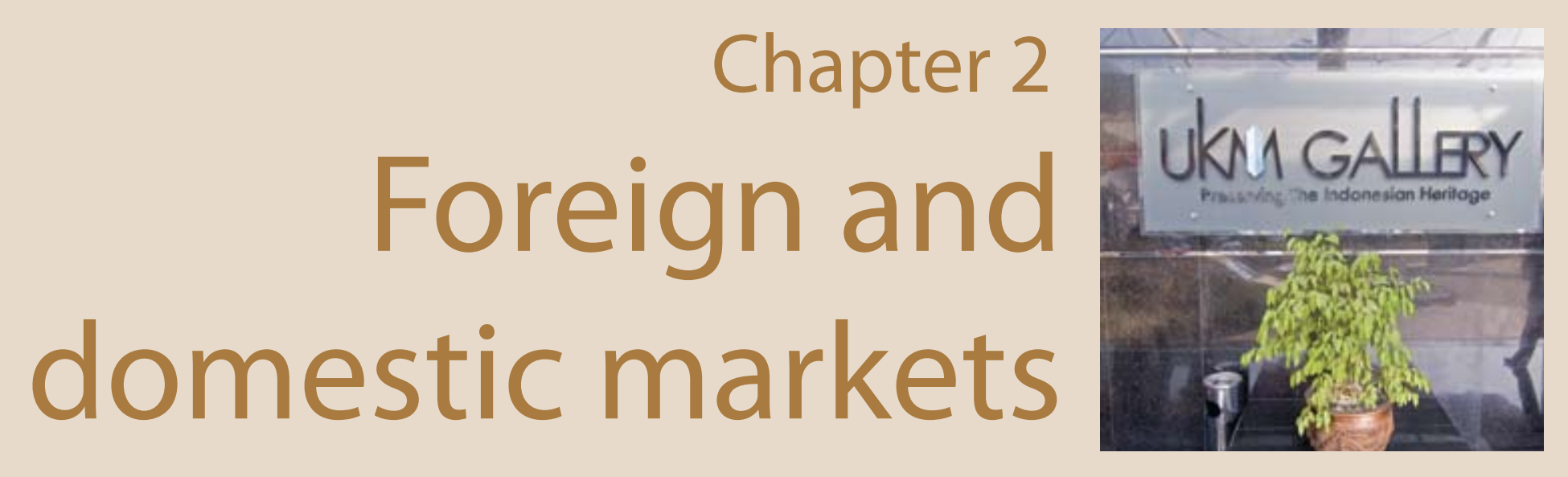




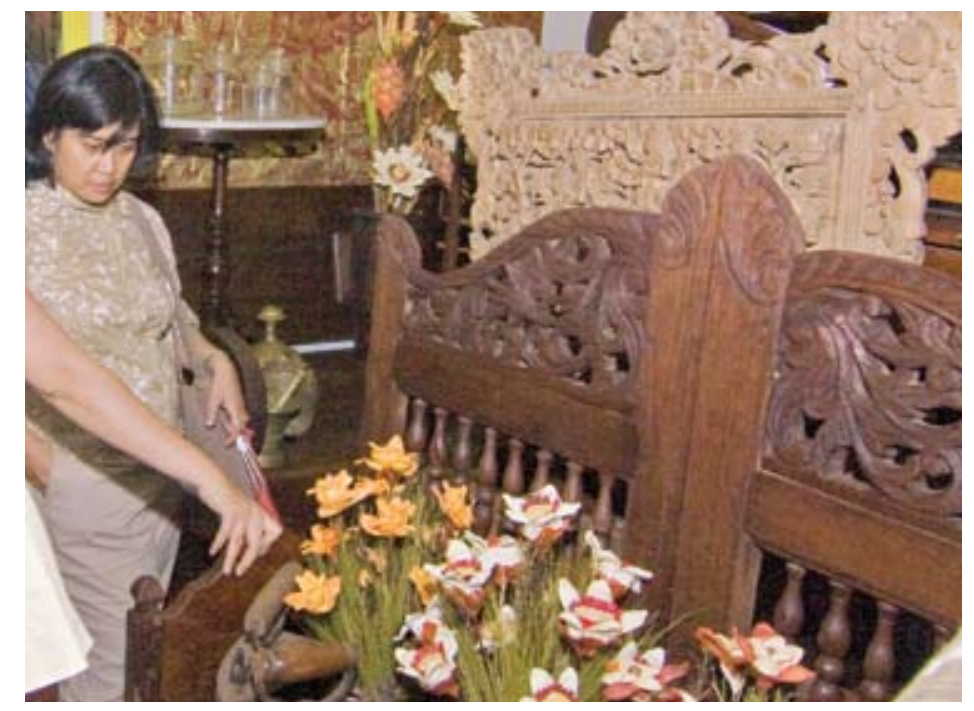

Prospective buyers survey furniture products

\section{Foreign and domestic markets}

Wood furniture is the most important export commodity produced in Jepara. Annual exports are valued at about USD 100 million. There are 510 wood furniture export companies in Jepara that export to 99 destination countries. The primary export destination countries are Australia, France, the United Kingdom, Hong Kong, Saudi Arabia, Spain, and the United States. Exporting companies identified eco-certification, bureaucratic burdens, legal requirements, raw material supply, capital and marketing as challenges for improving their competitive advantage. 

DEBINDO

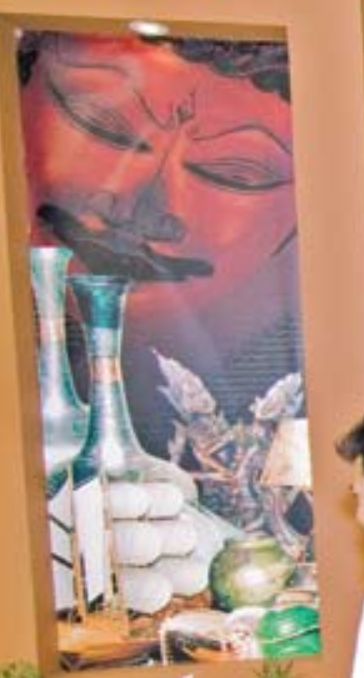

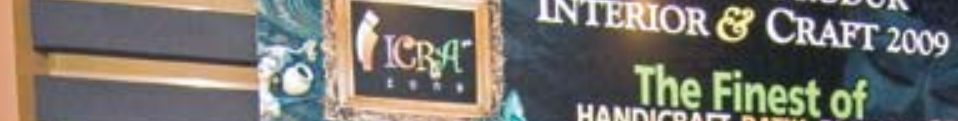
(1) $19-23^{-2}$ JEWANDIGA Finest of

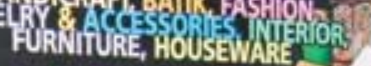

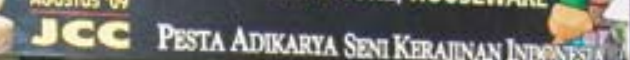
$=$ ris

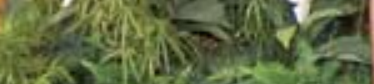
Q

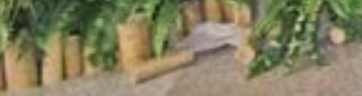

A buyer shopping for wooden furniture products
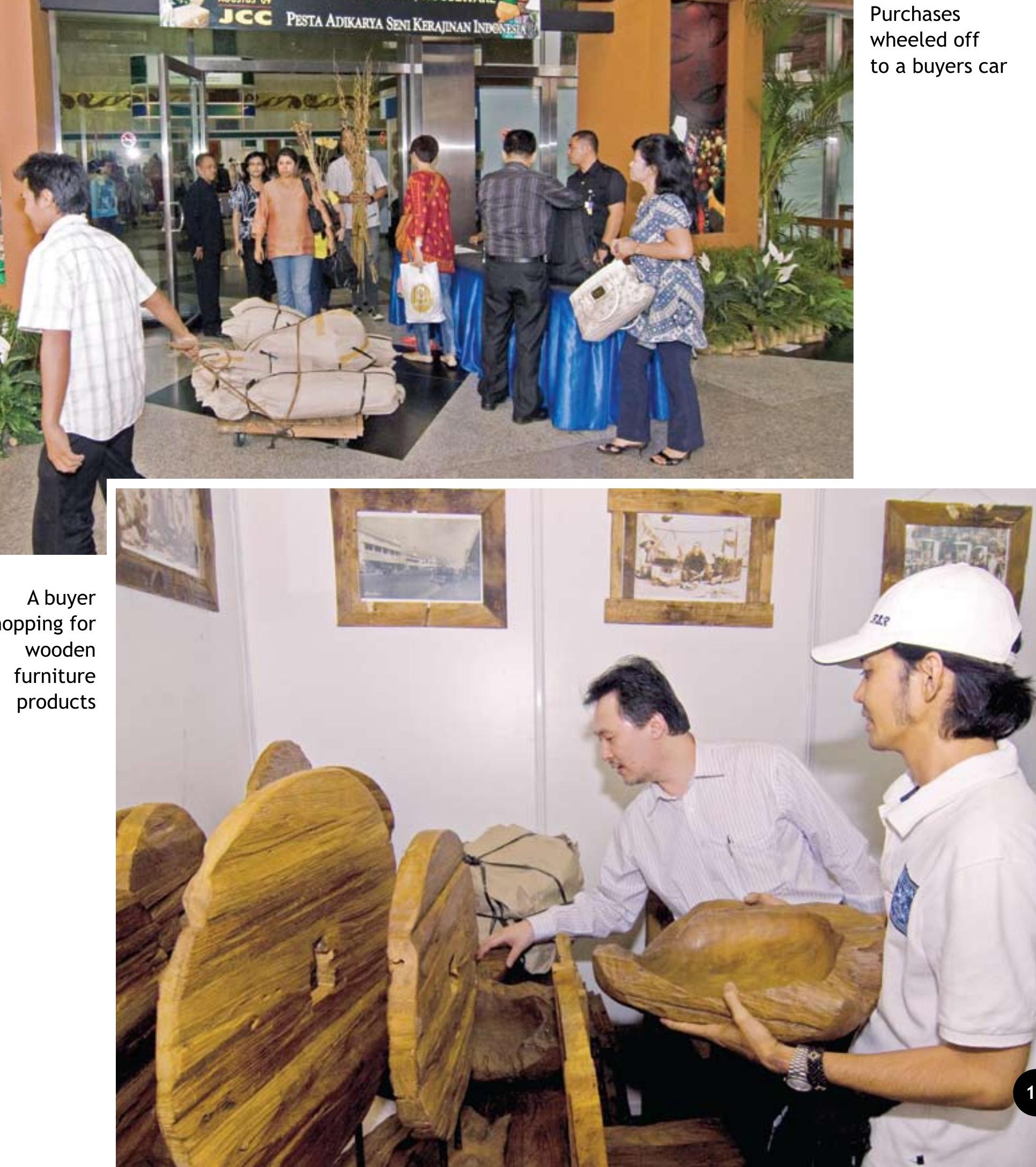

wheeled off

to a buyers car 


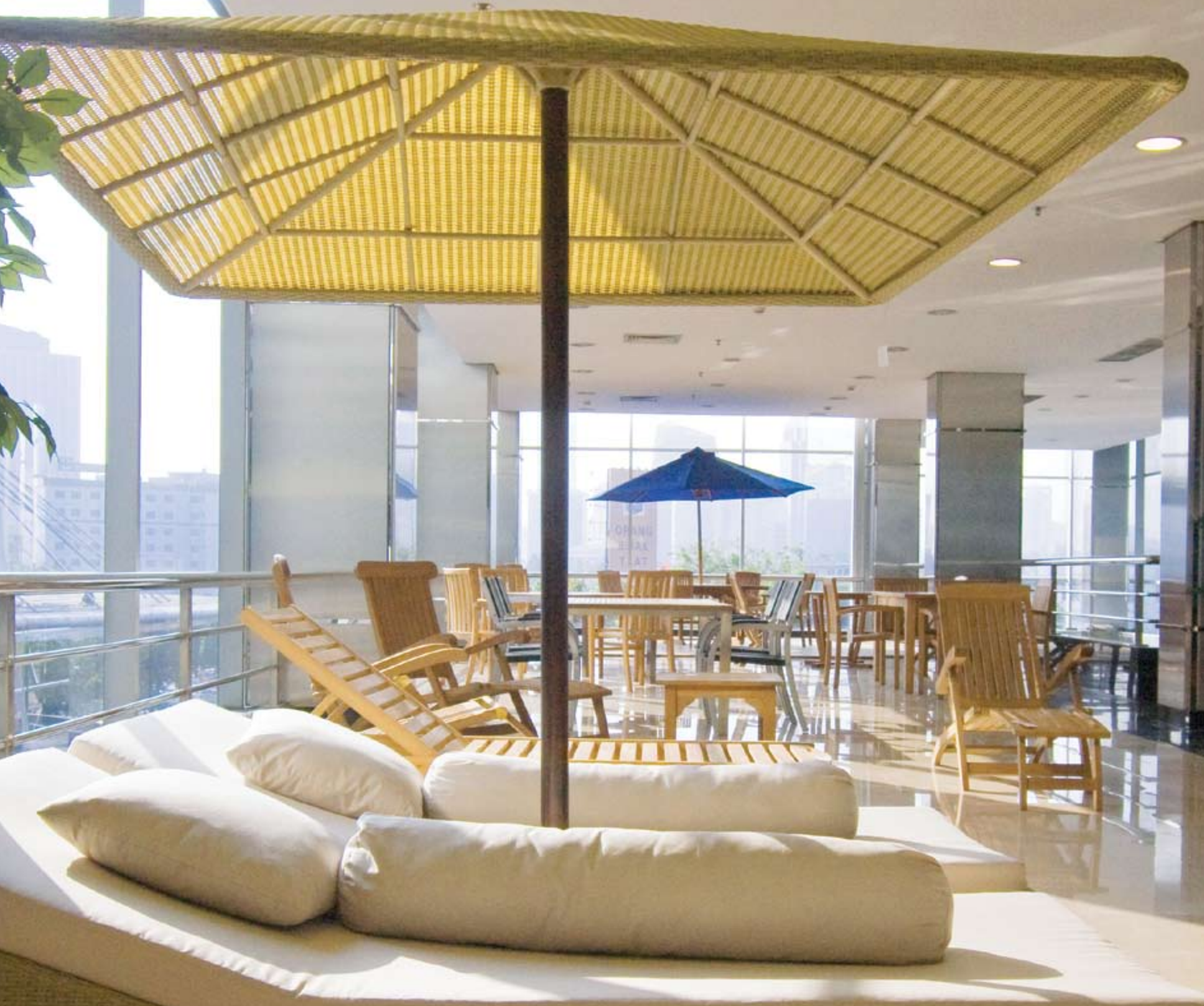

An upmarket furniture showroom in Jakarta 


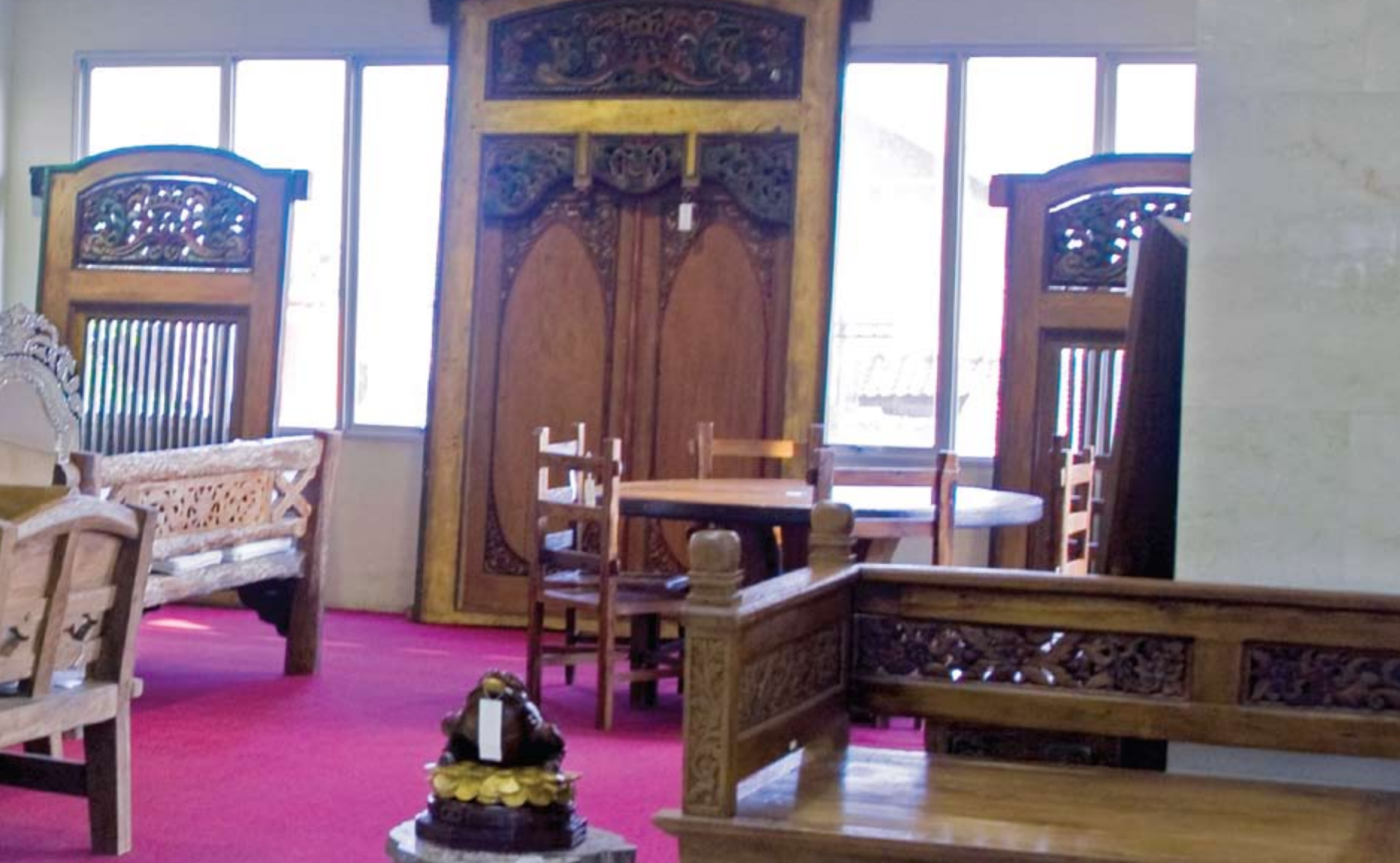

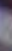
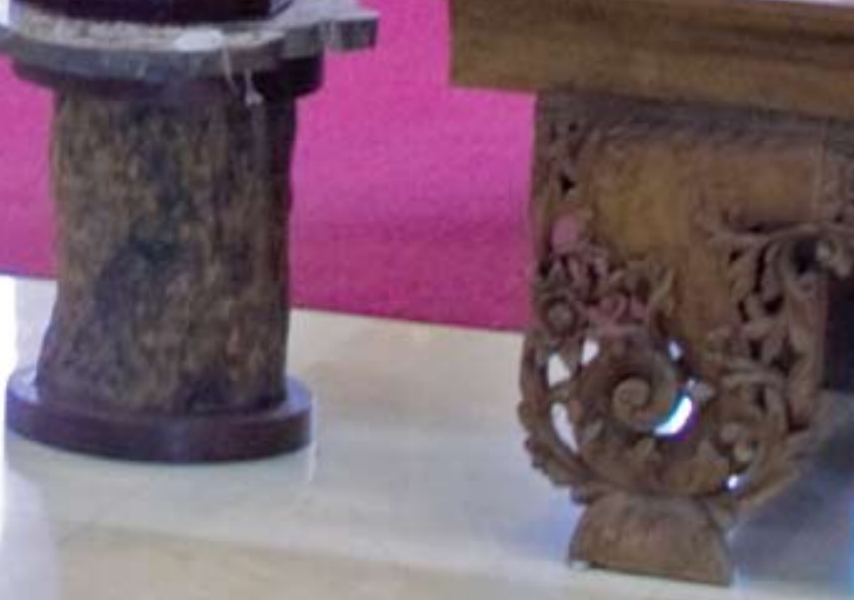

sage
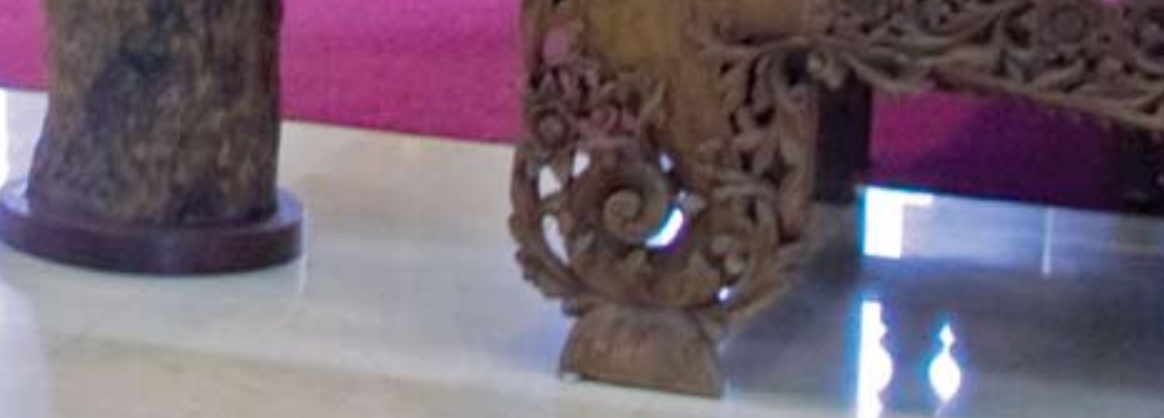


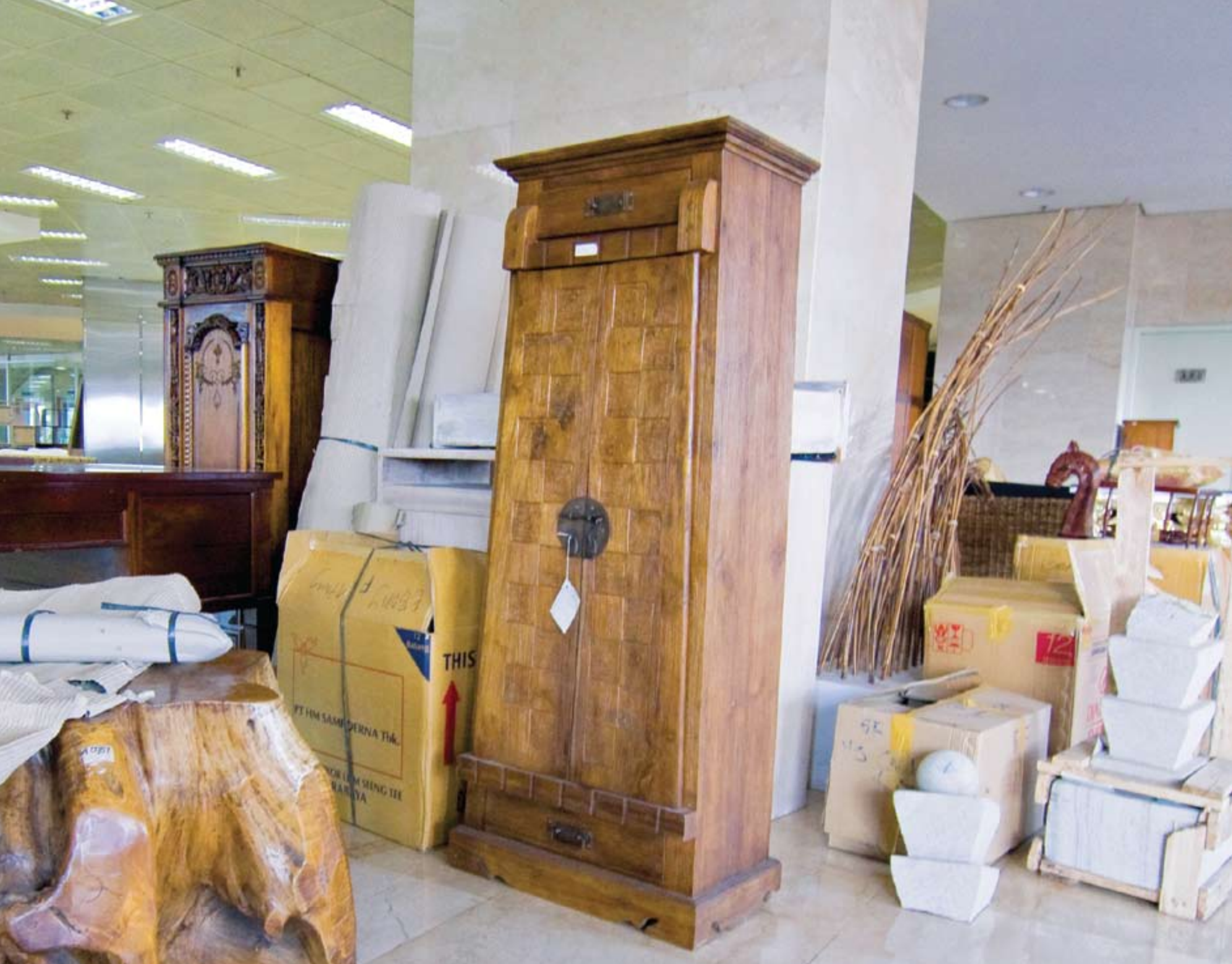




\section{OULOADUNG URNITURE FAIR 2009}

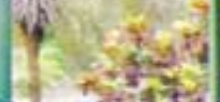

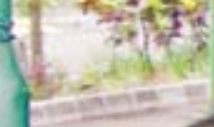

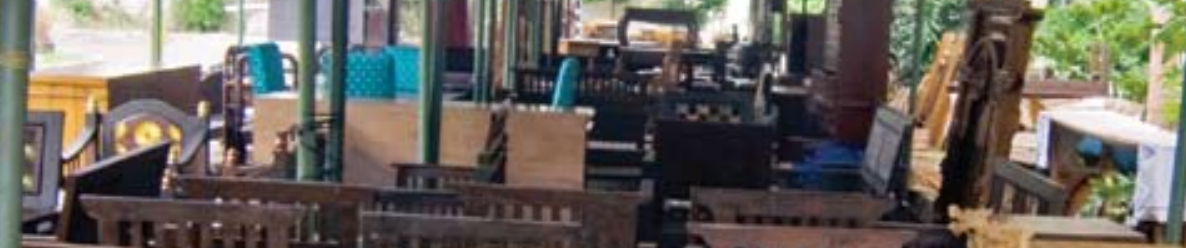

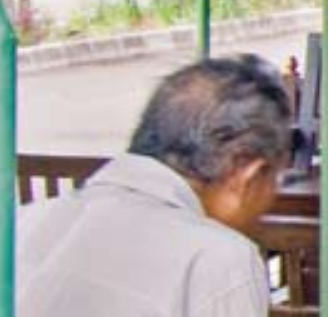

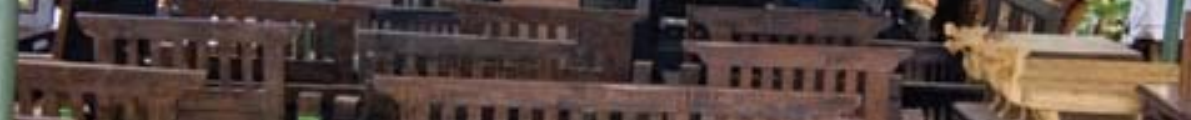

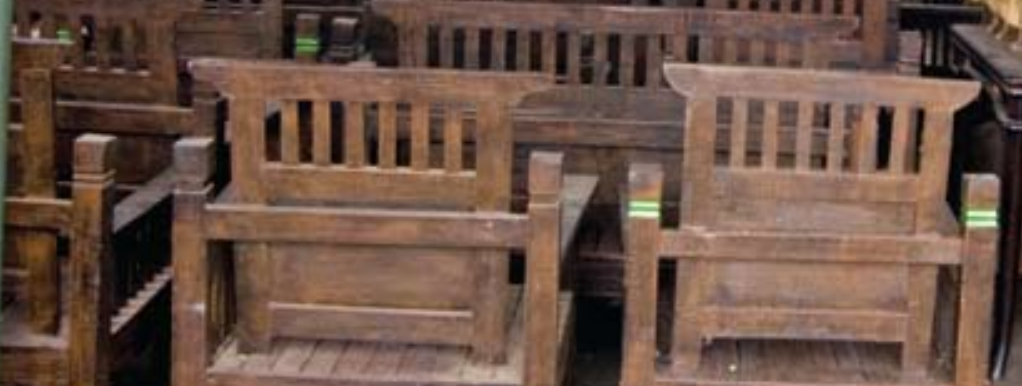

Product rejects on sale at a furniture bazaar in Jakarta

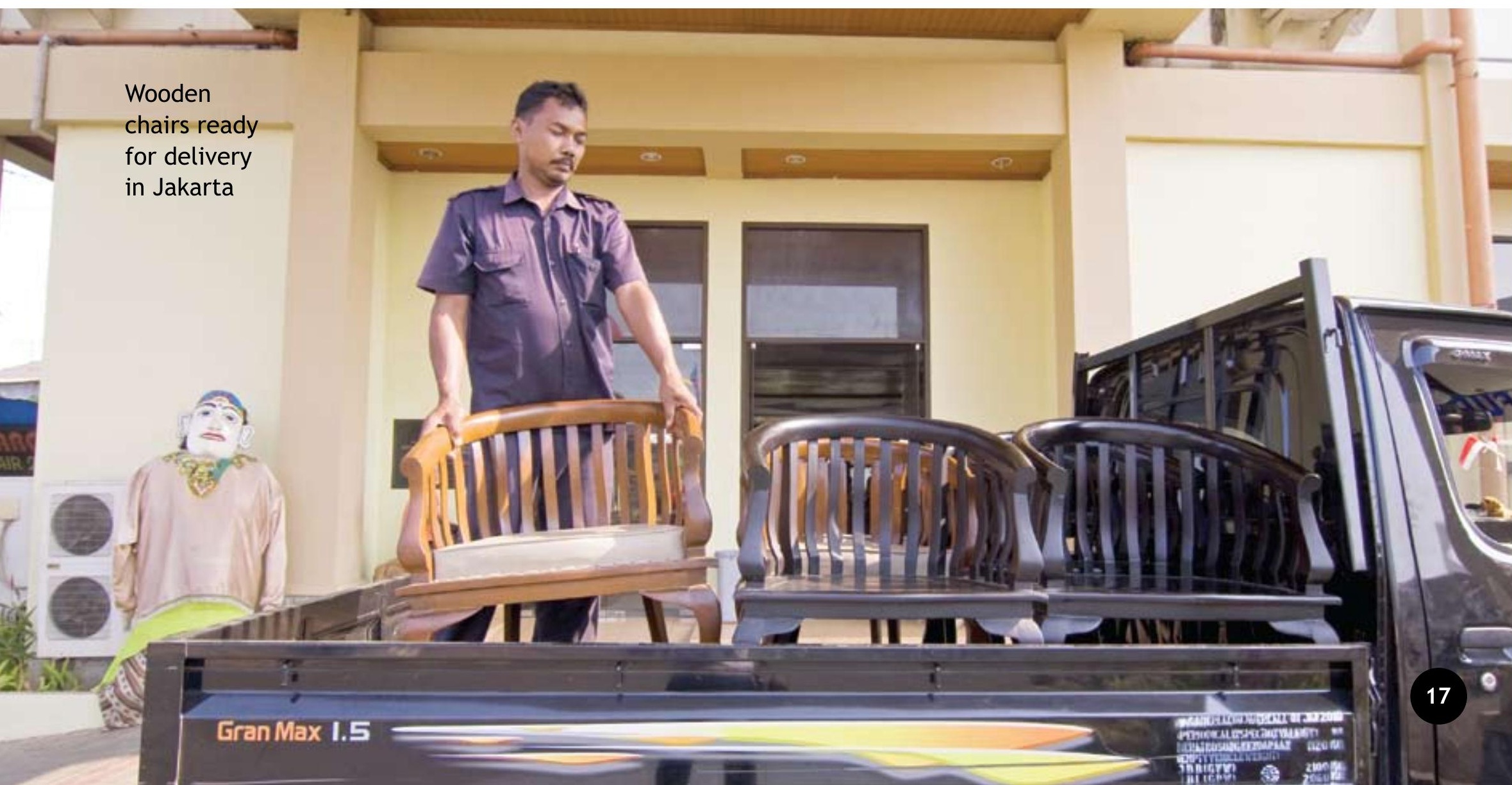



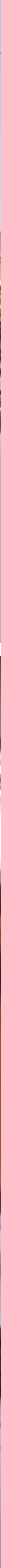


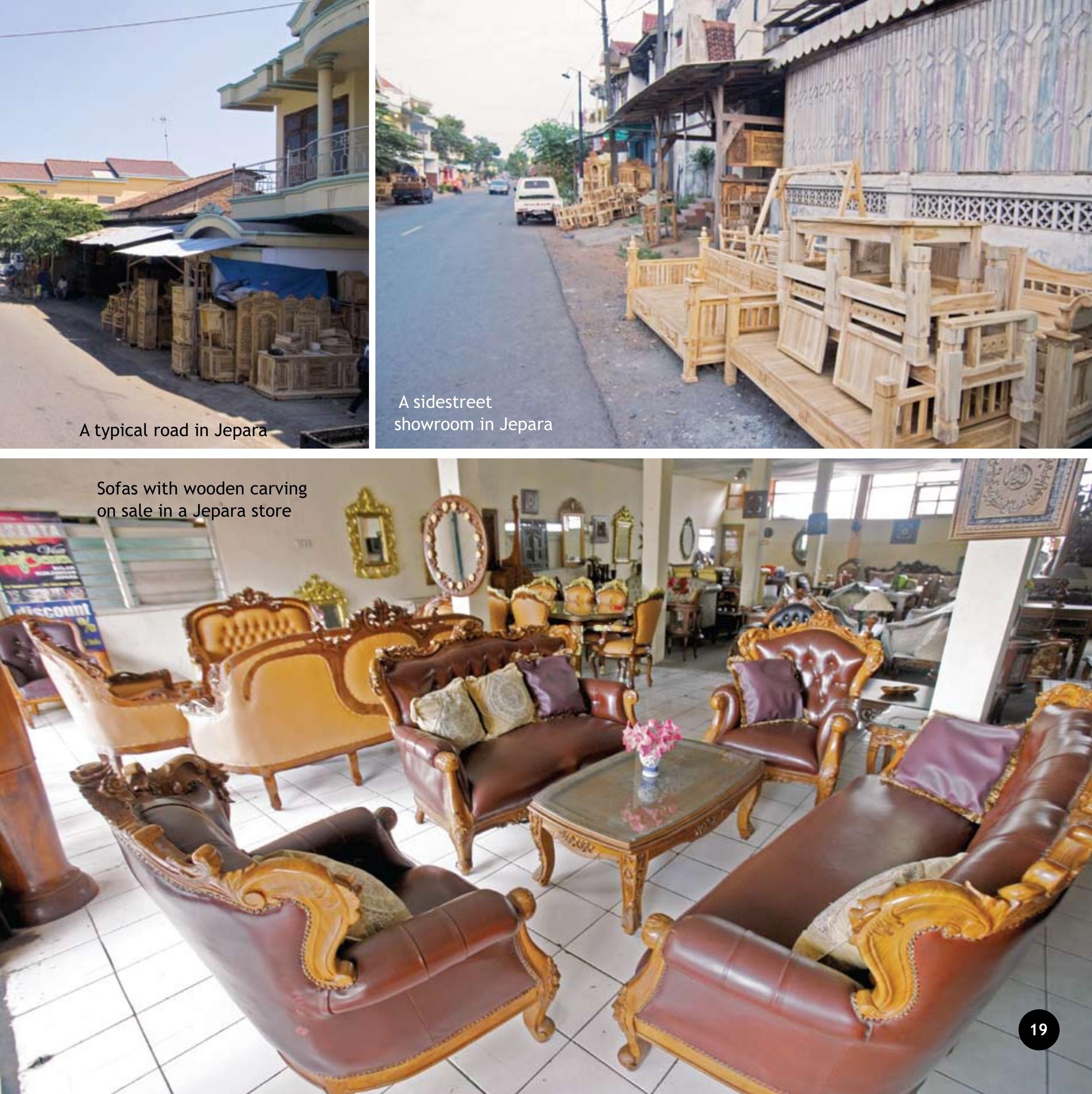




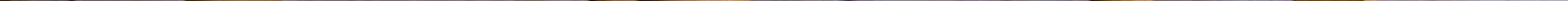




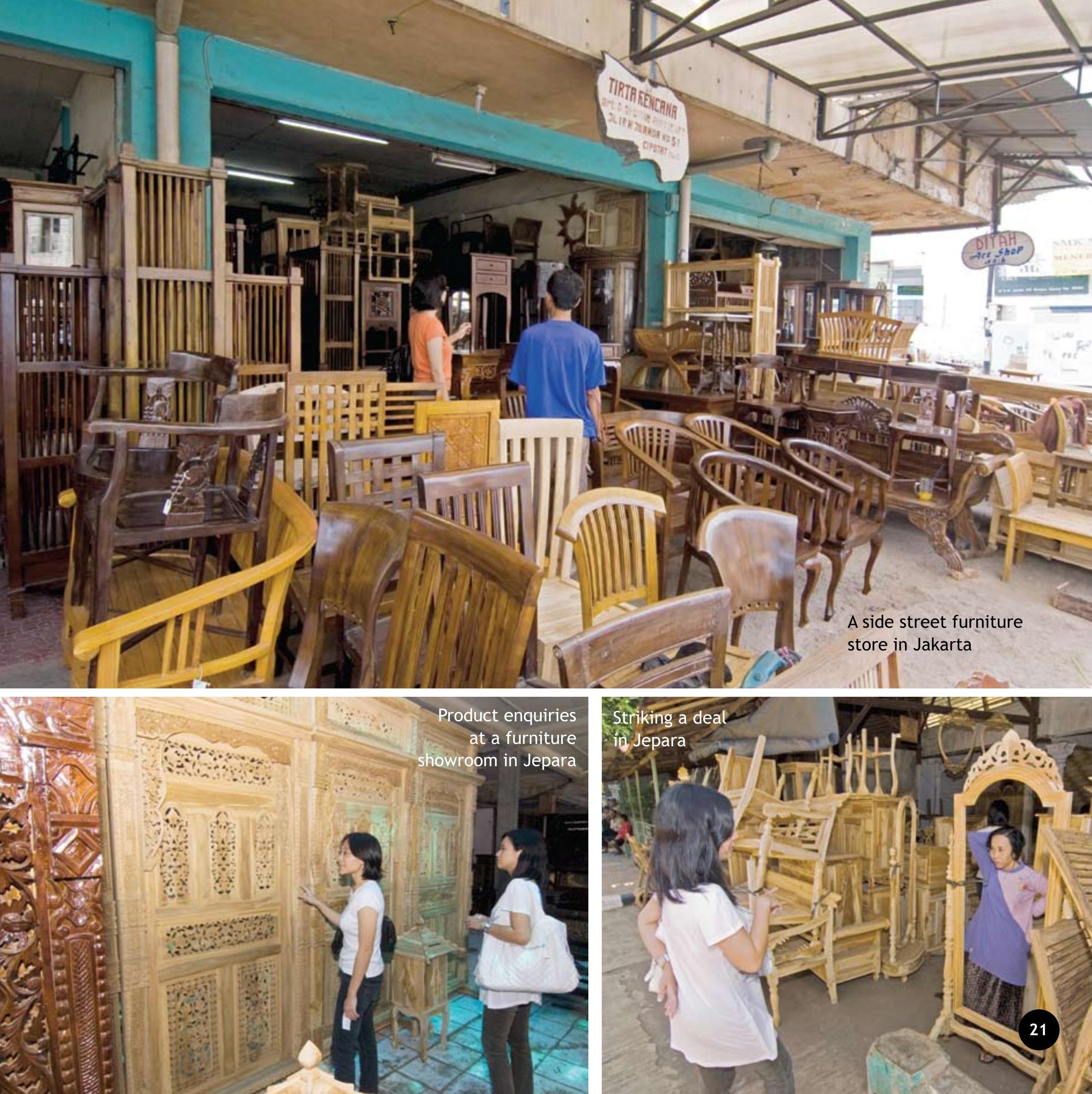



$\frac{\omega^{2}}{3} \times 1=0$

2.

-

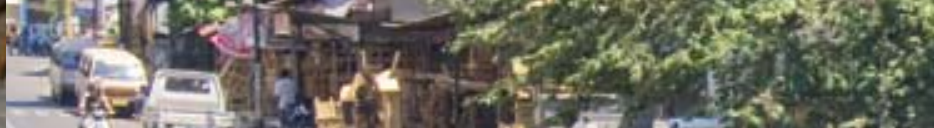

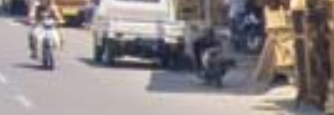
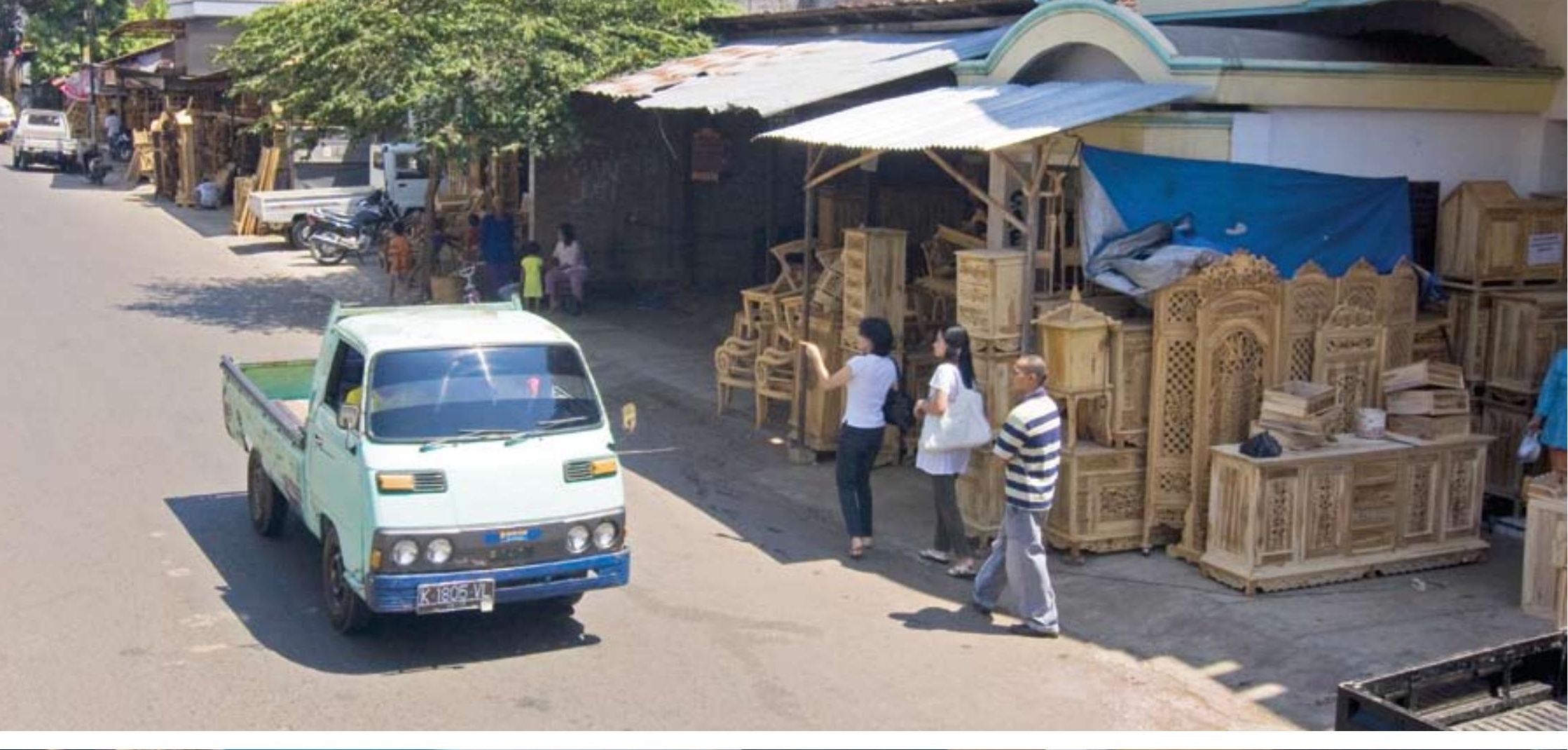

S.

201.
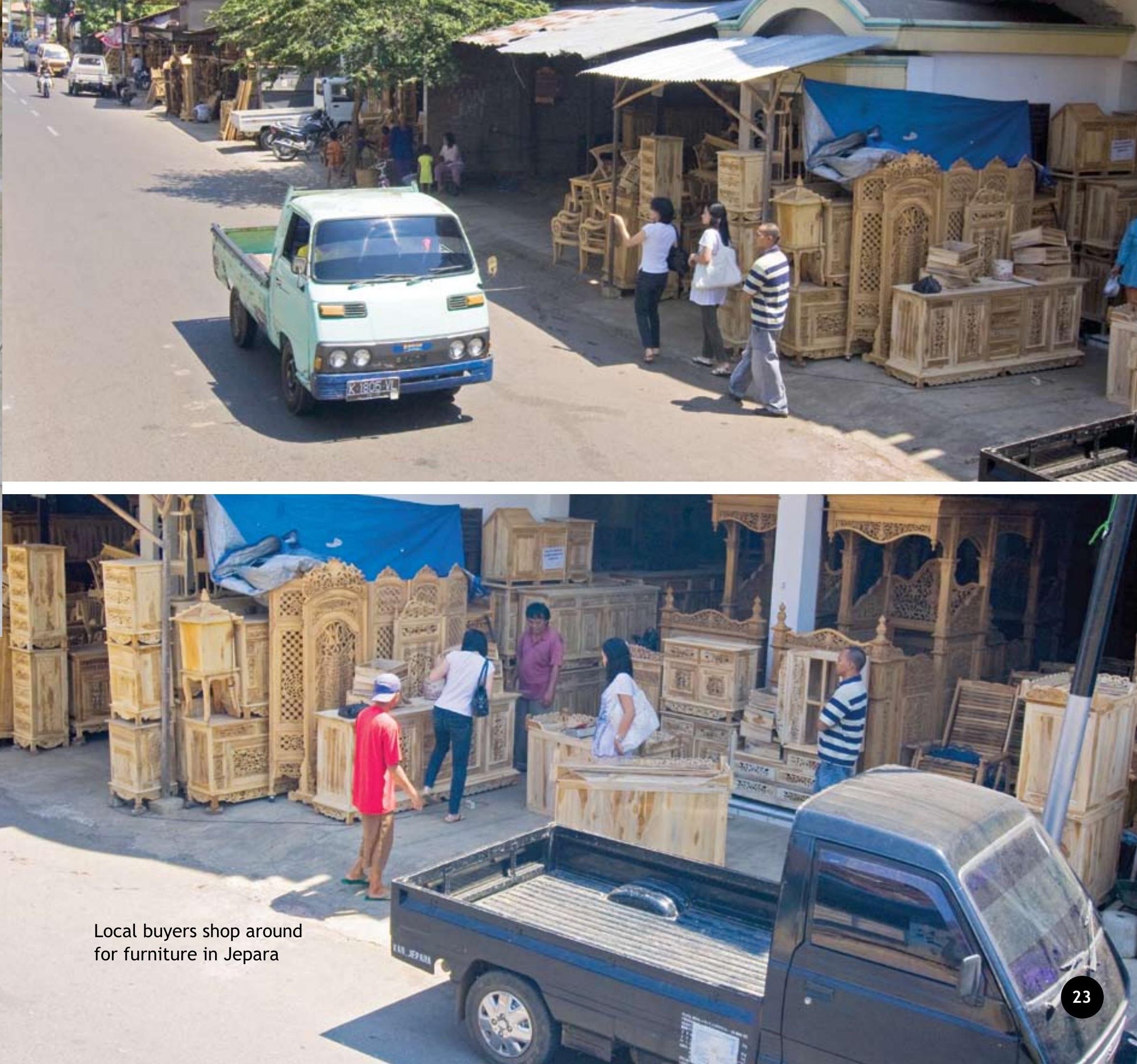


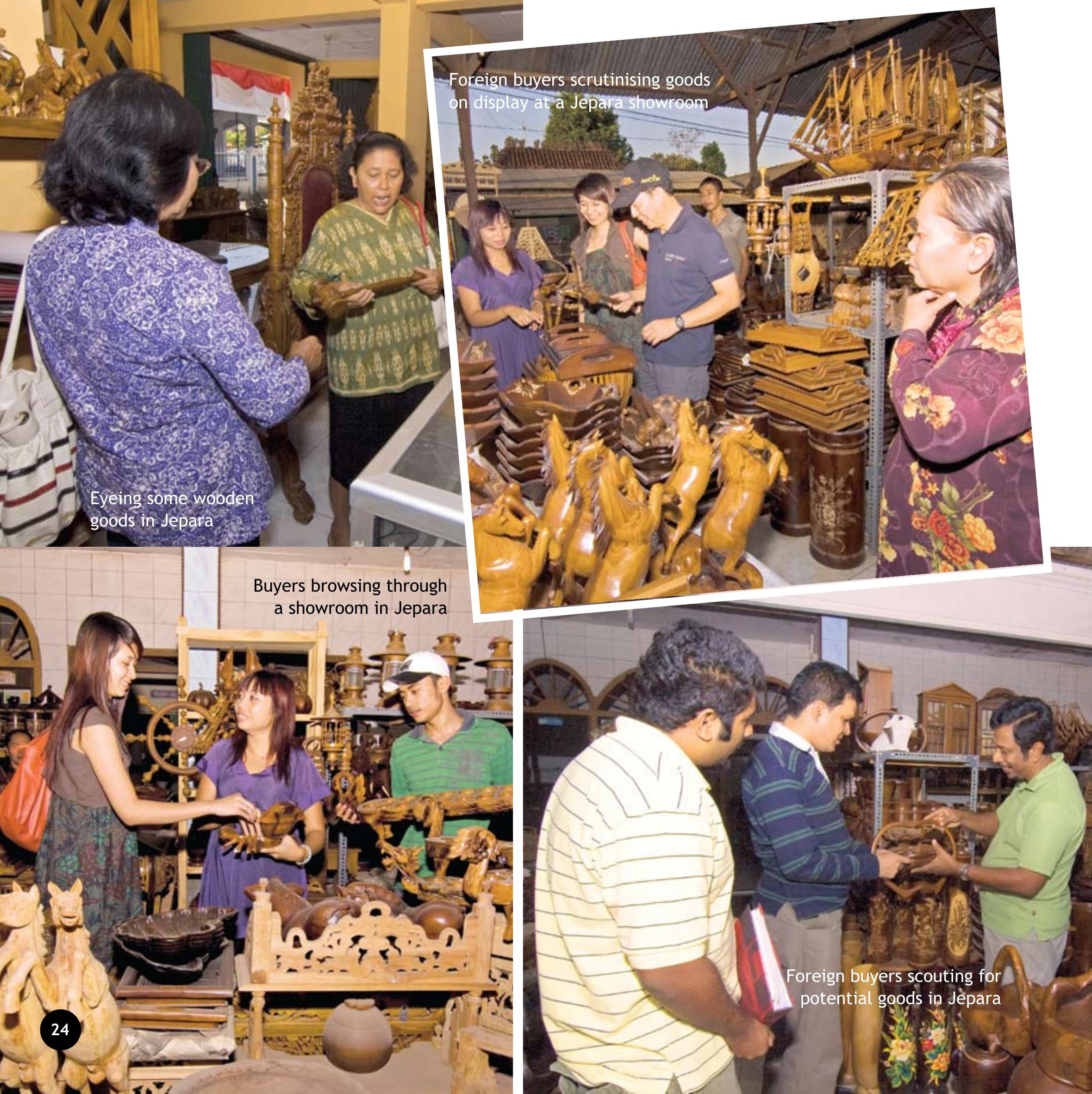




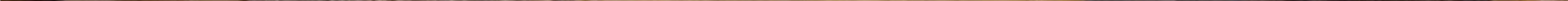




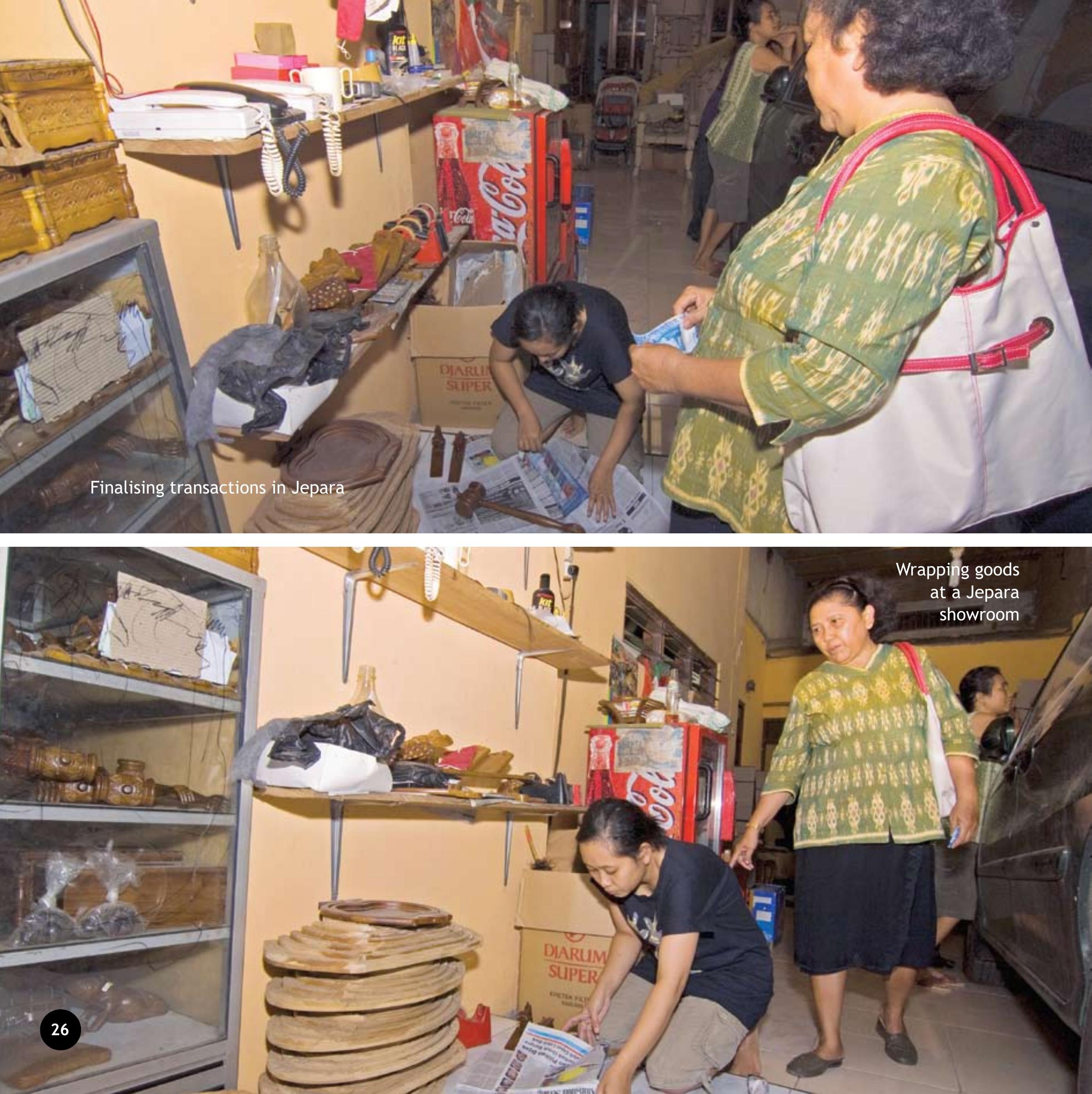




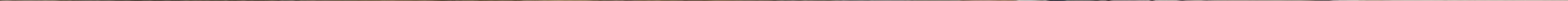




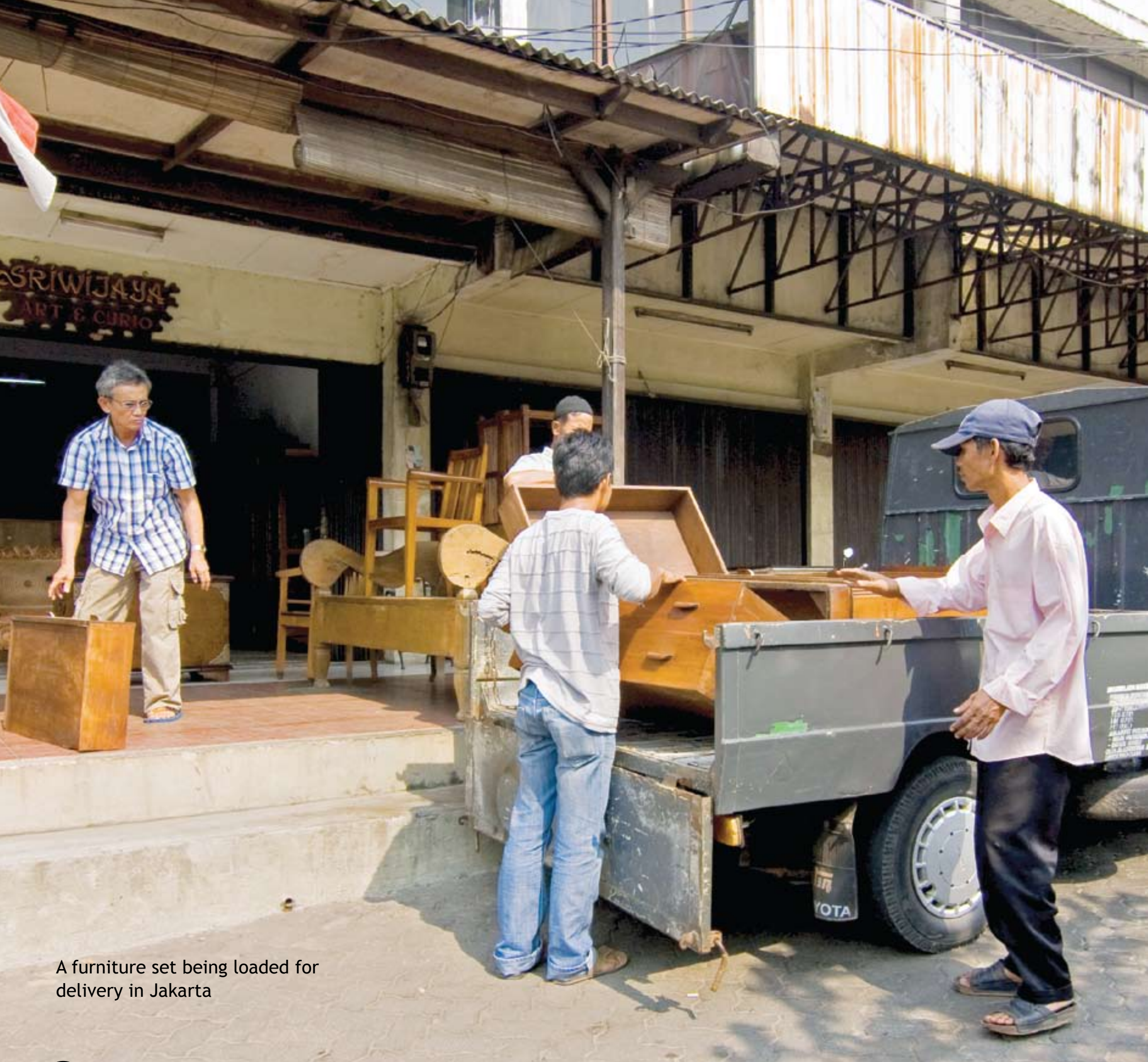




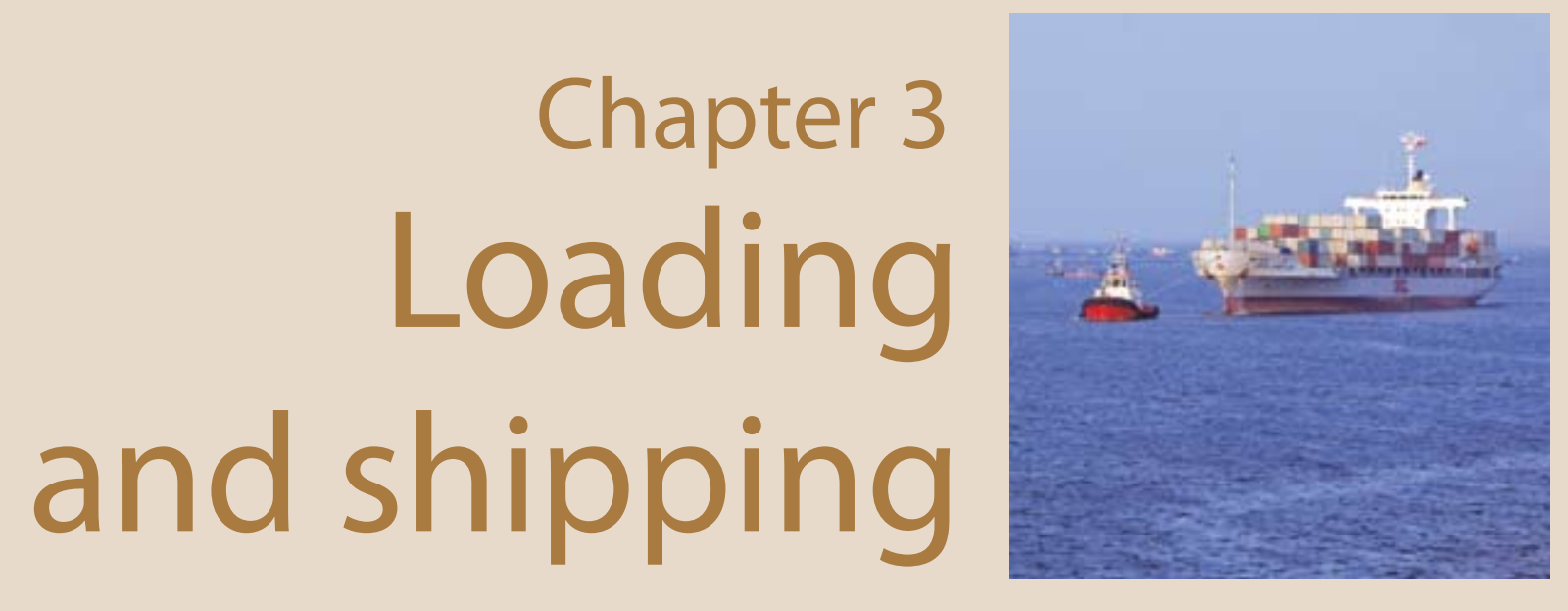




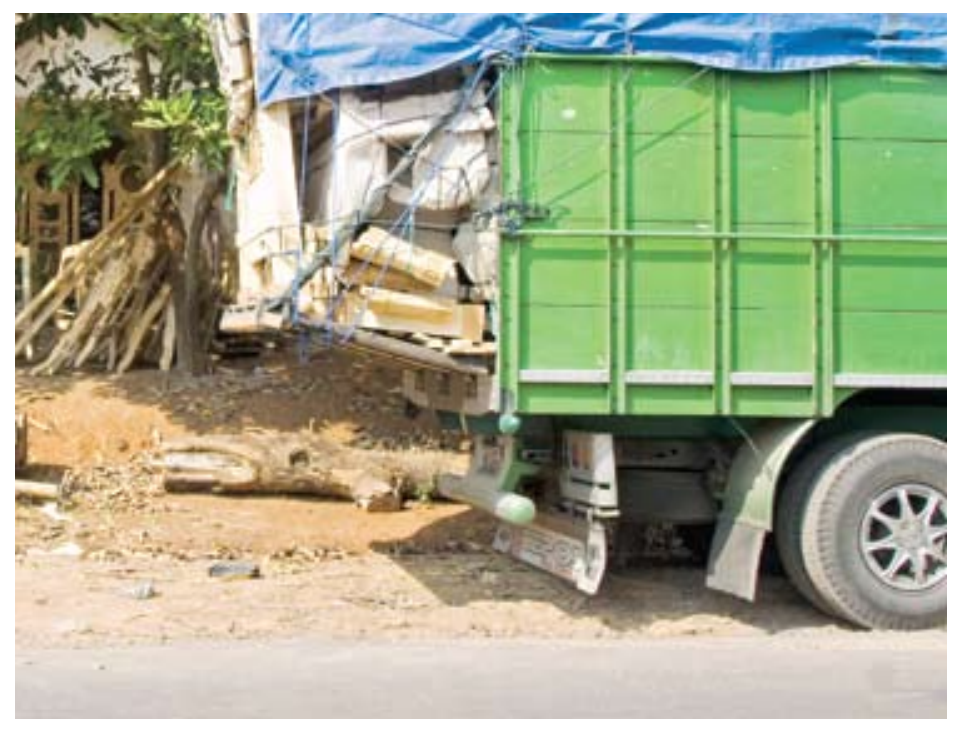

A fully-loaded truck

\section{Loading and shipping}

Furniture is shipped to local and foreign markets using different transportation channels. Trucks move furniture straight from the producers to local showrooms and promotion centres throughout Indonesia. Delivery to foreign markets requires a more complex chain of transportation. Pickup trucks collect products from producers and deliver them to a nearby container, arranged by an exporting company. Once the container is loaded, it is sent to the harbour for shipment. Upon arrival at the harbour, containers are stored to await document clearance from the customs office, then uploaded to container ships. It can take a couple of days or several weeks for a fully-loaded container of furniture to arrive at its overseas destination. 


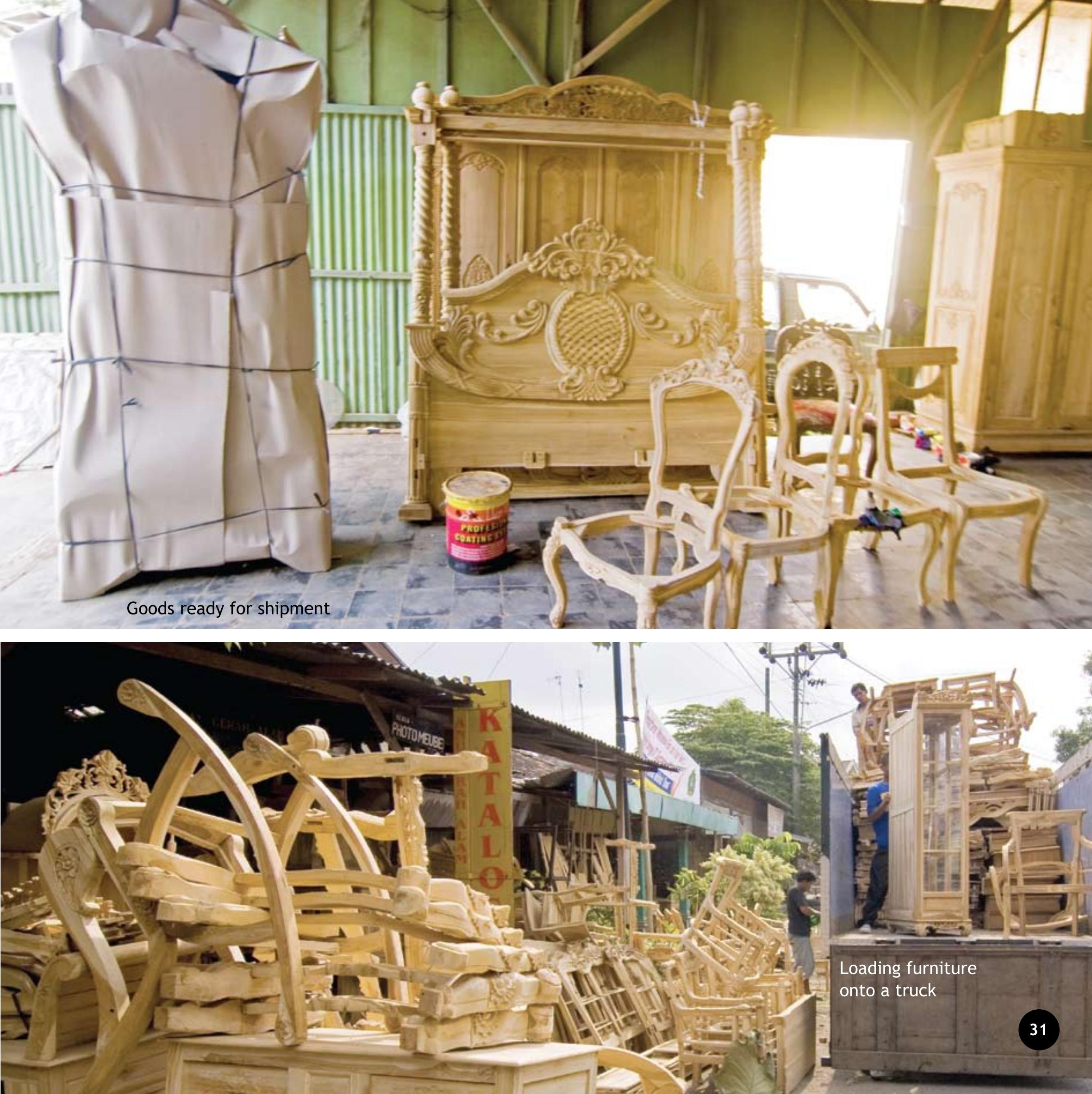


8x+4)

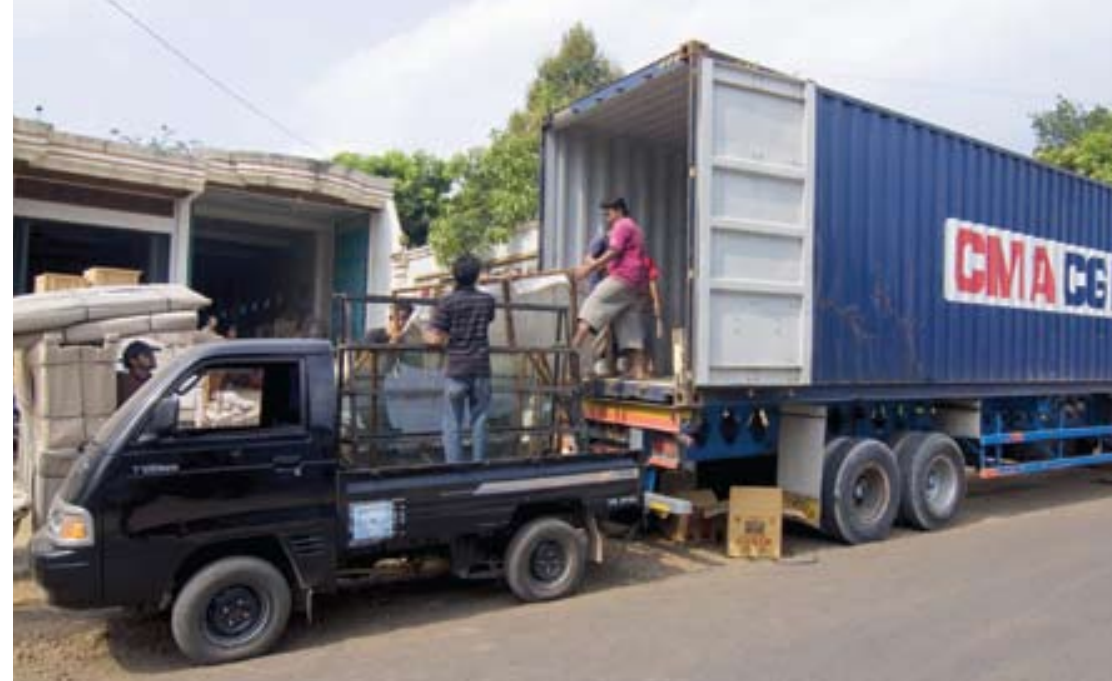

Loading a container

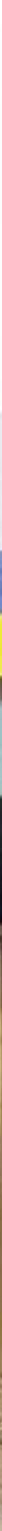



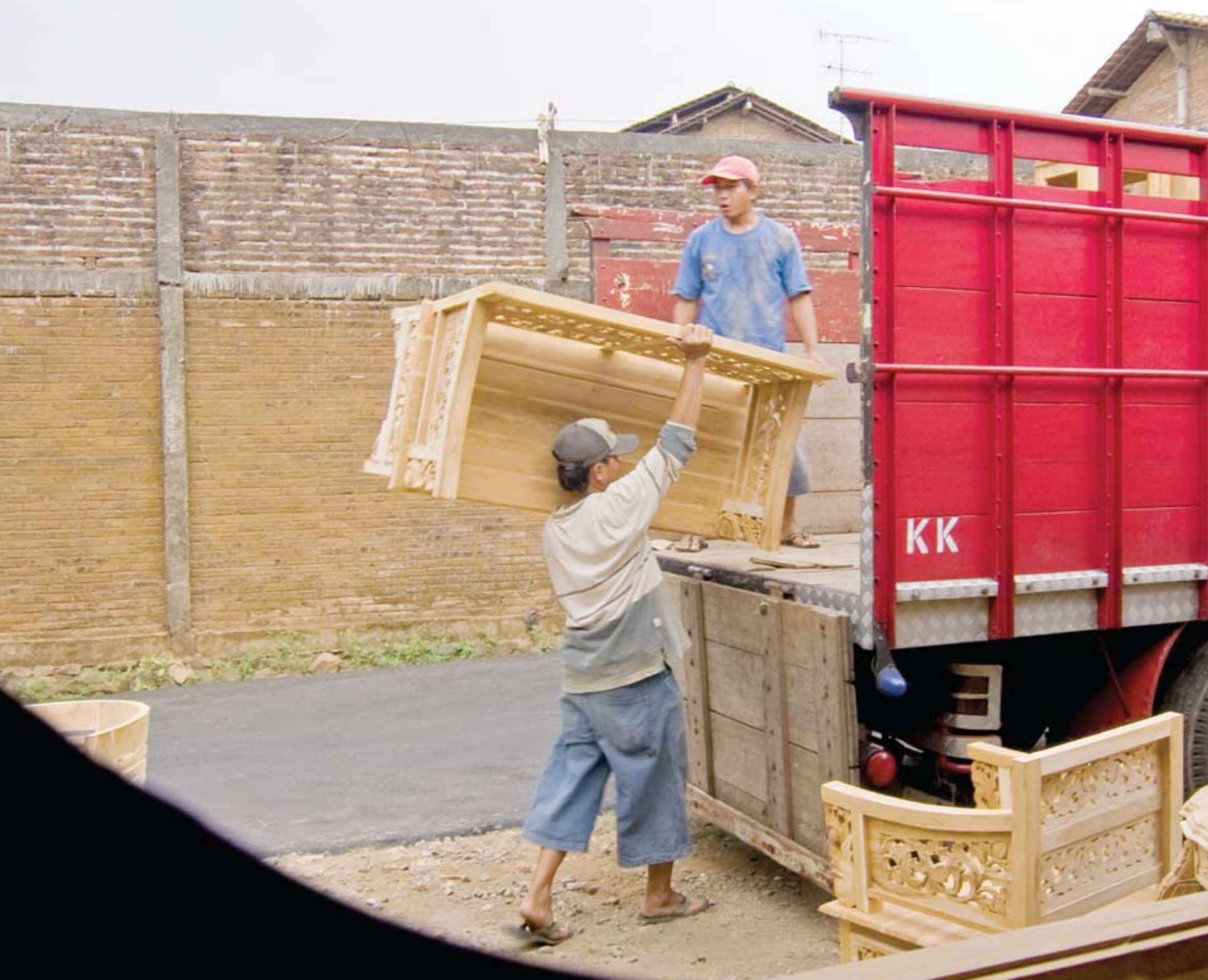

$+\frac{3}{2}$ 


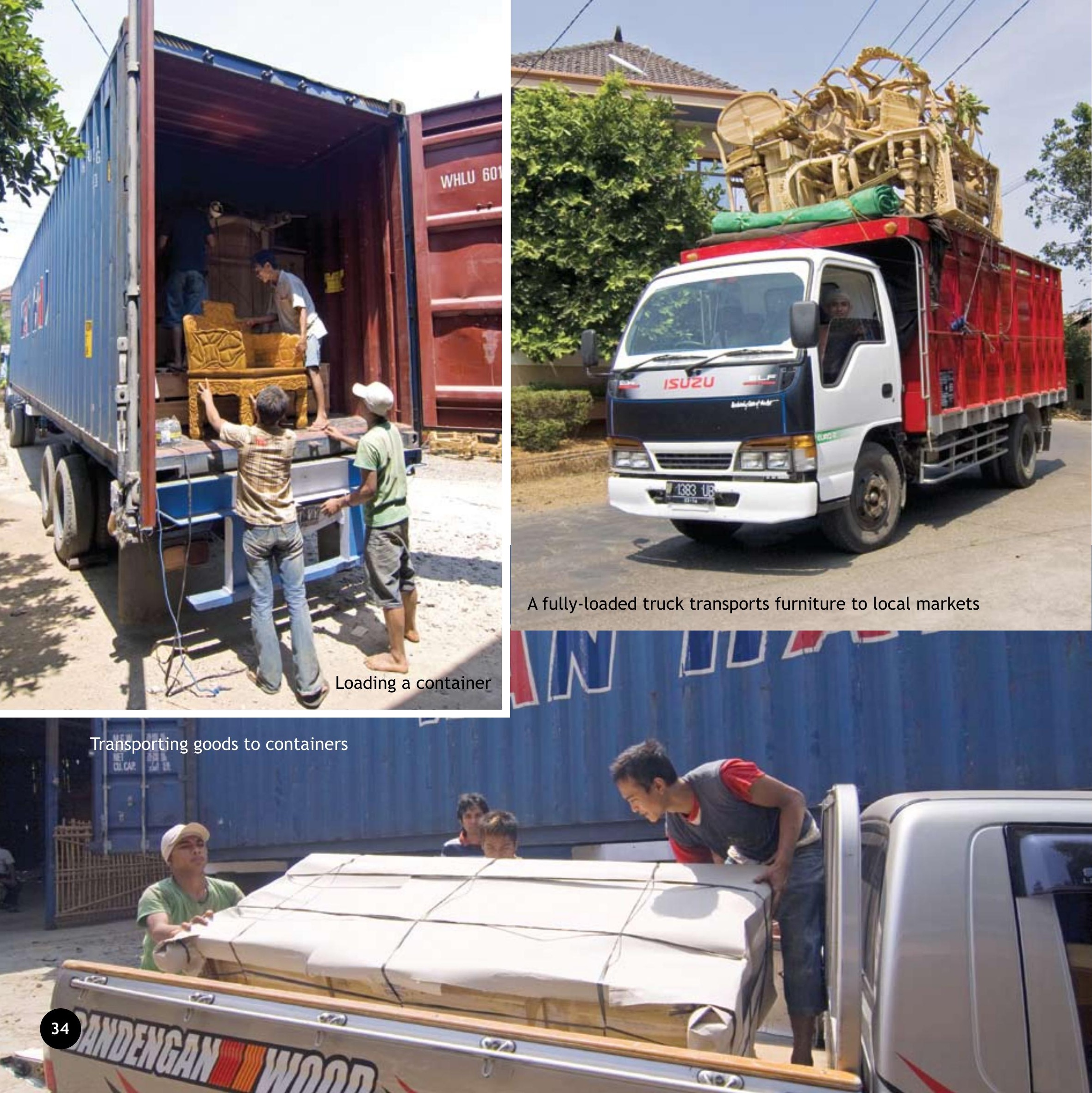




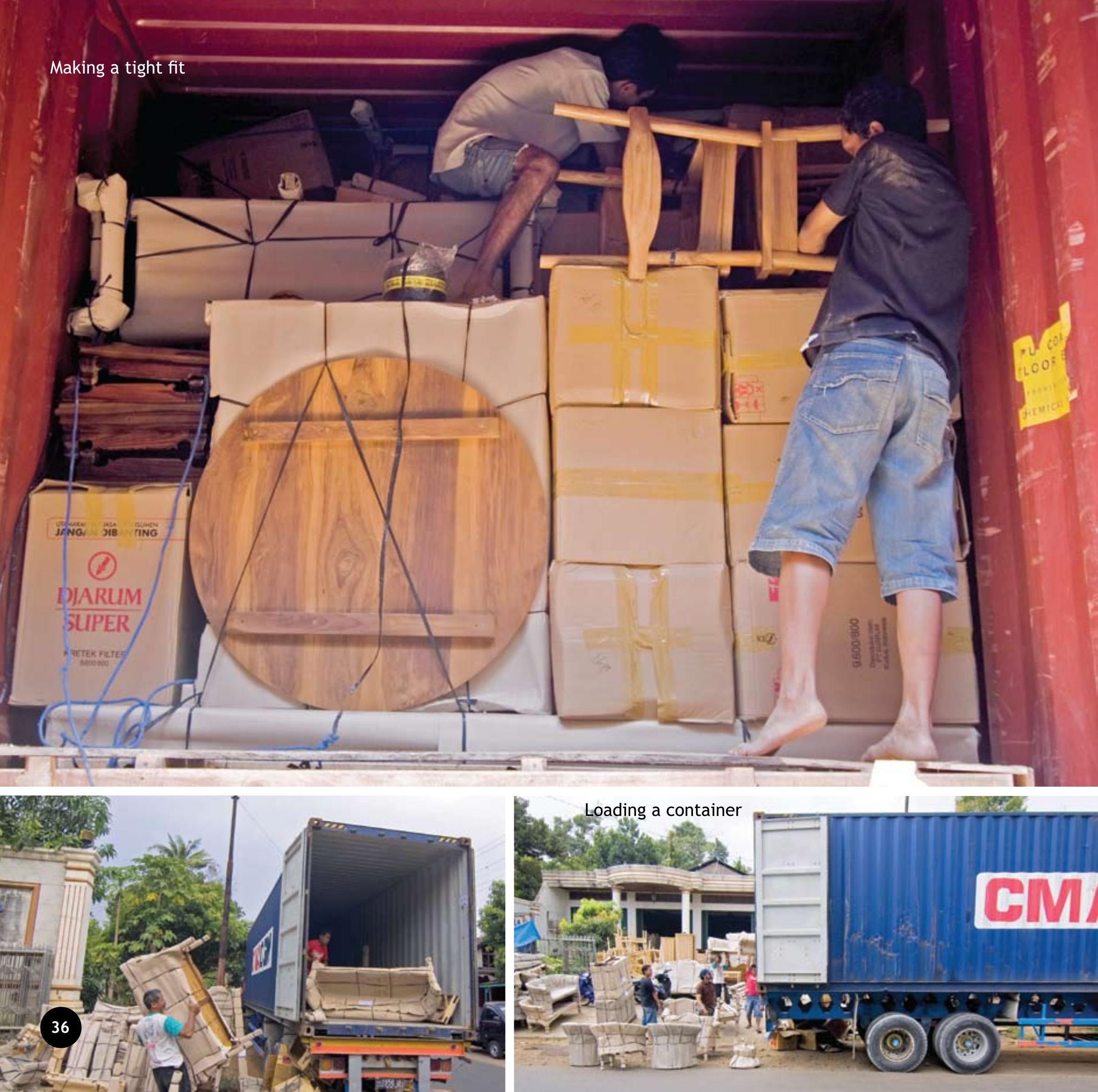




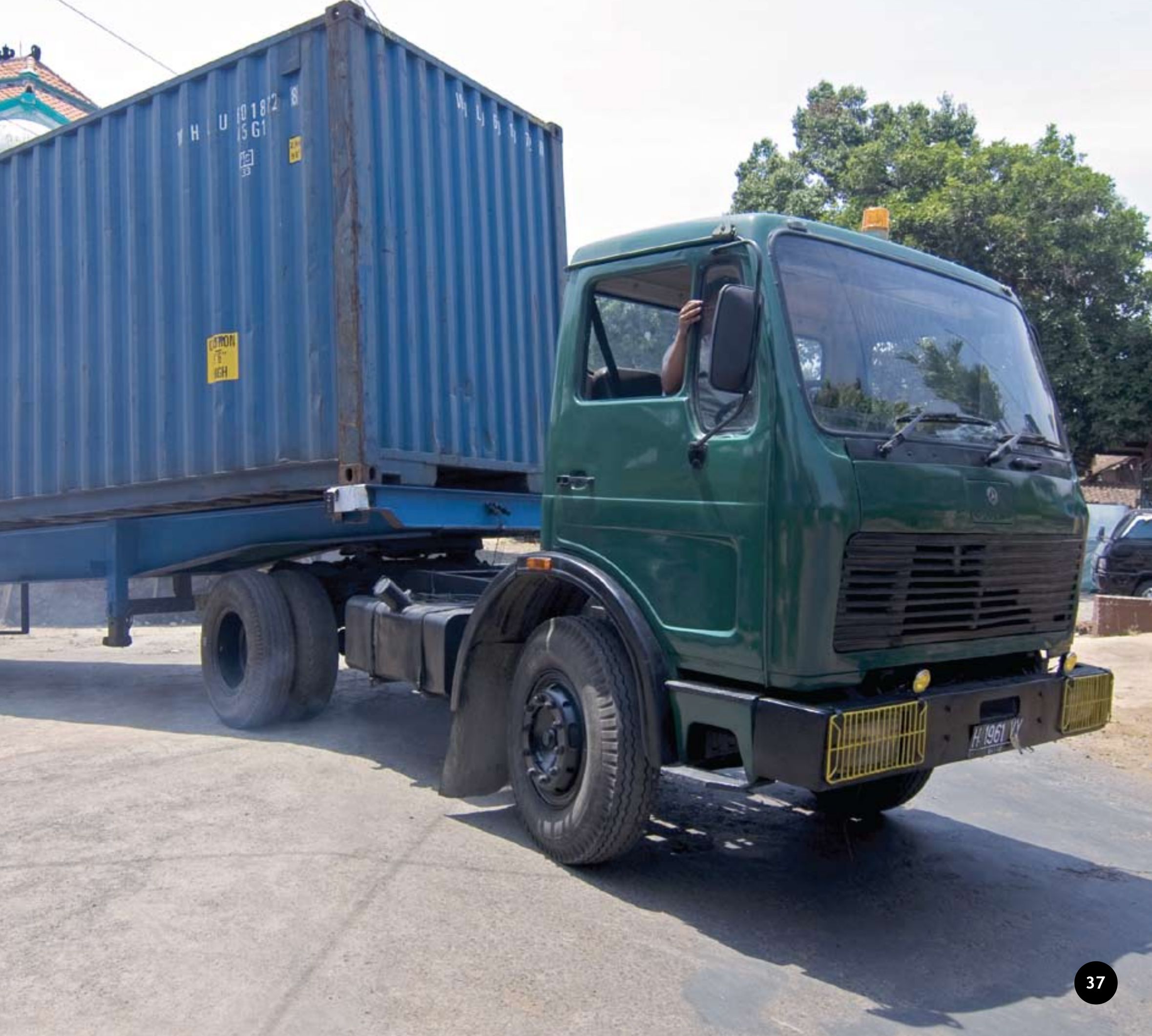




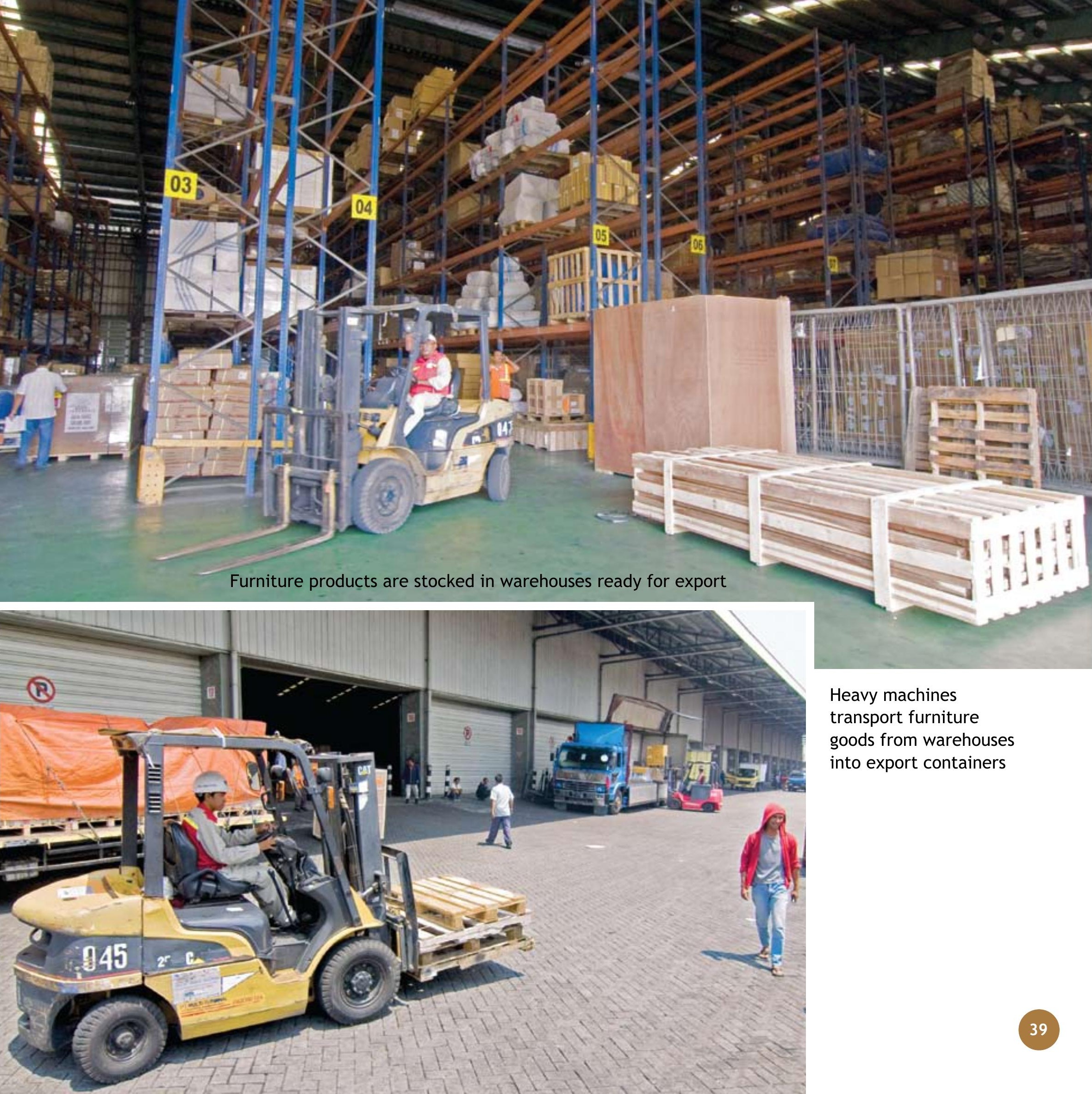




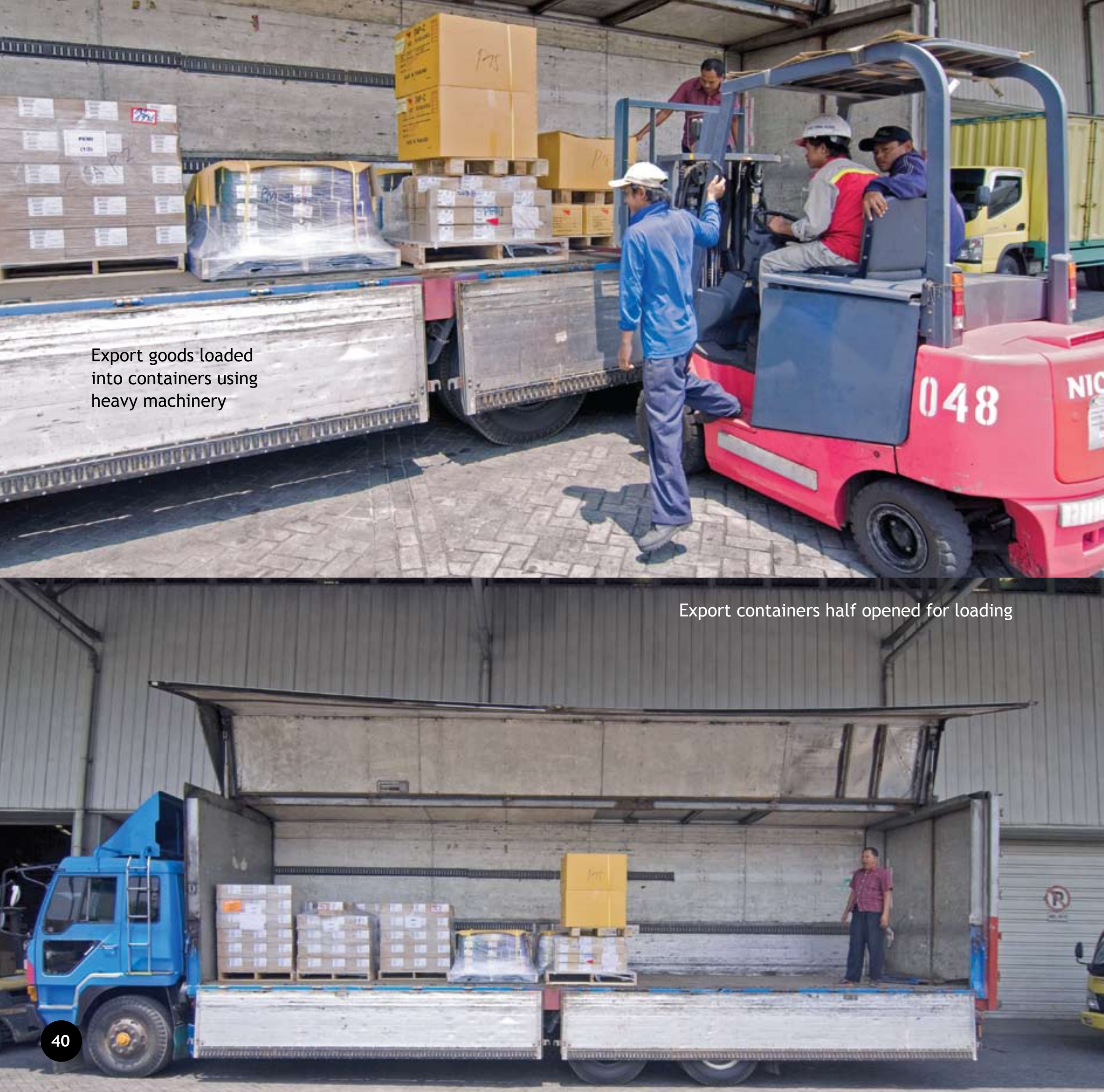



Container parking lot

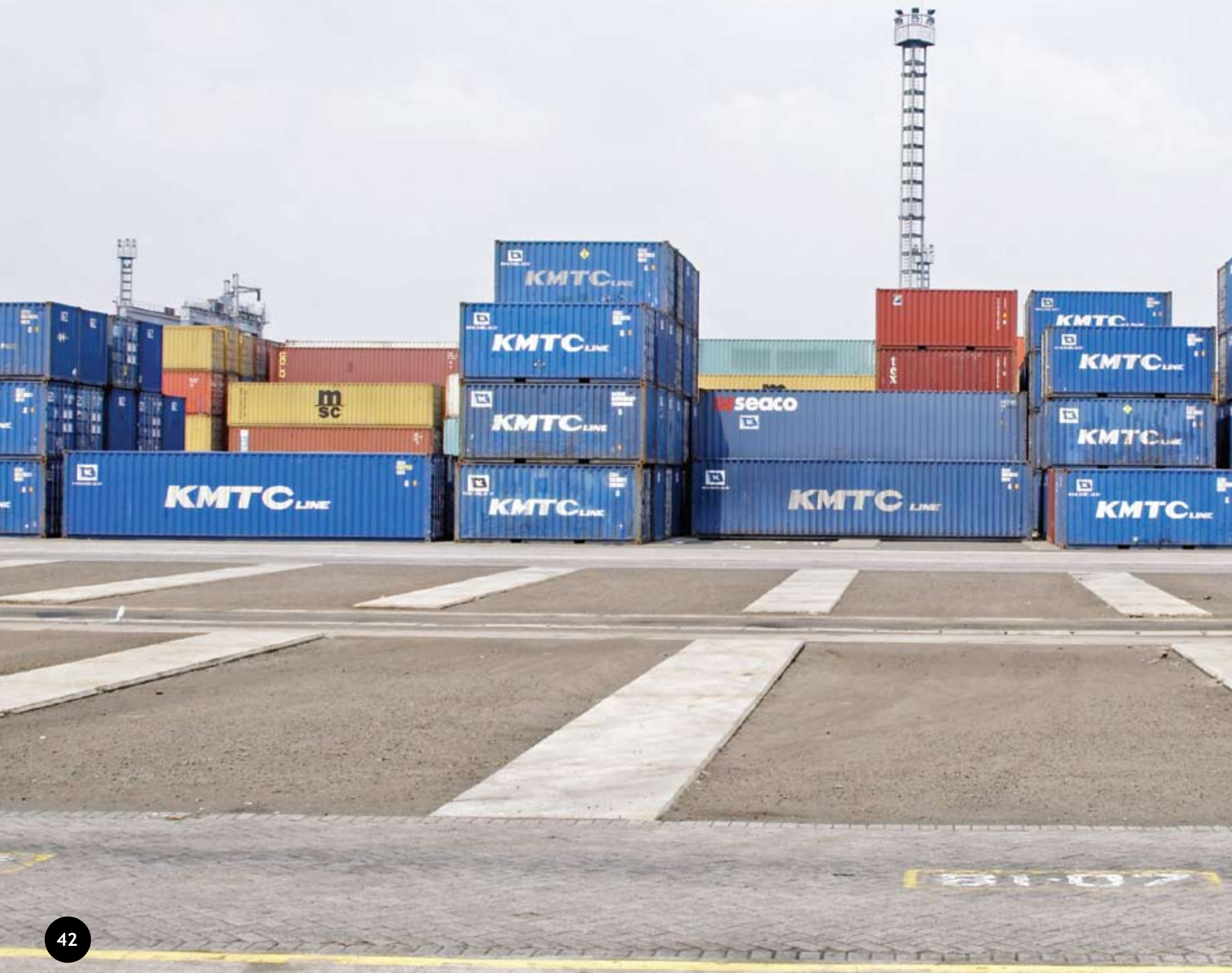



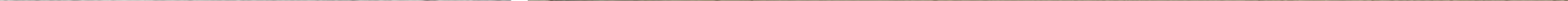



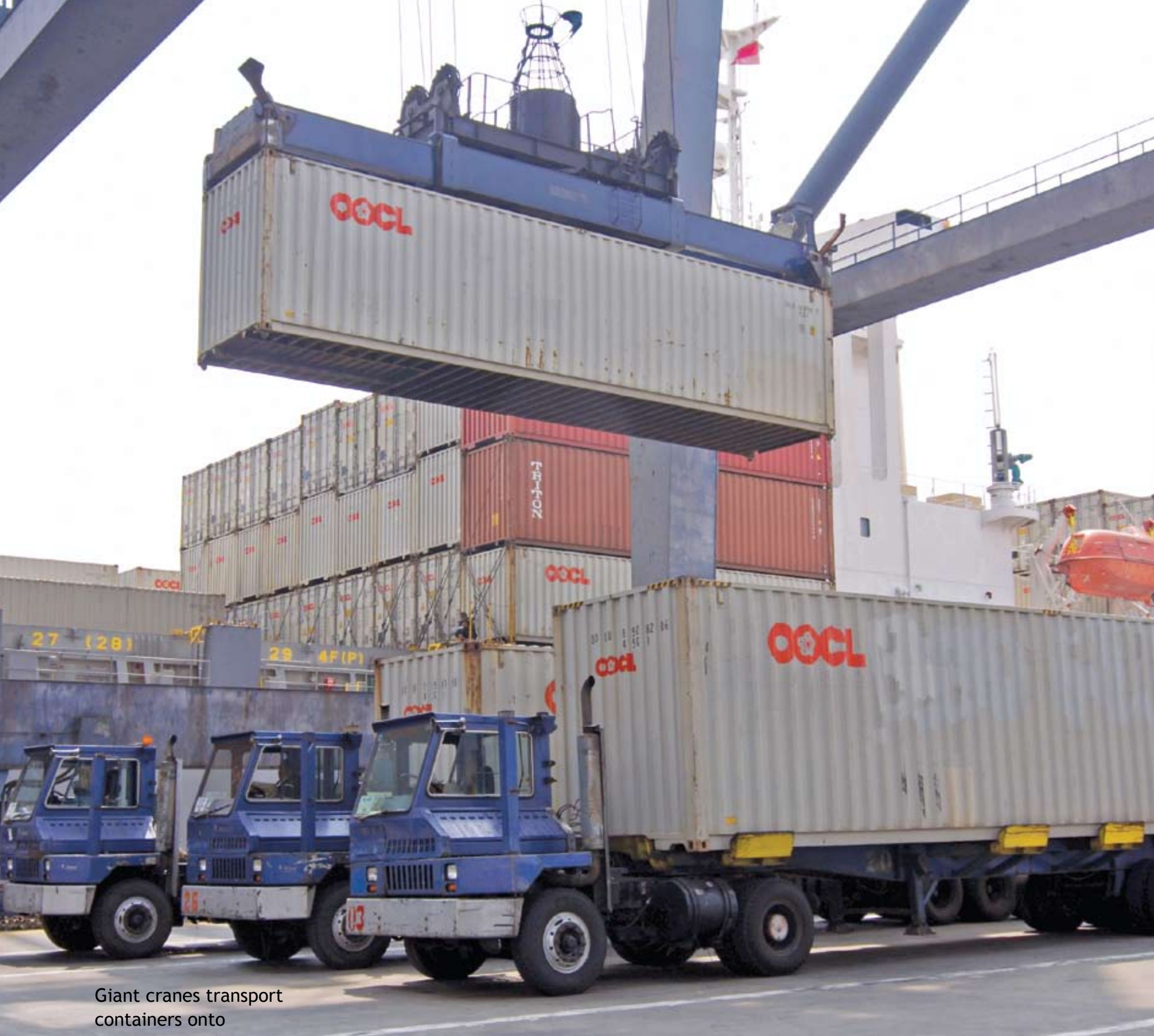

containers onto

shipping vessels 

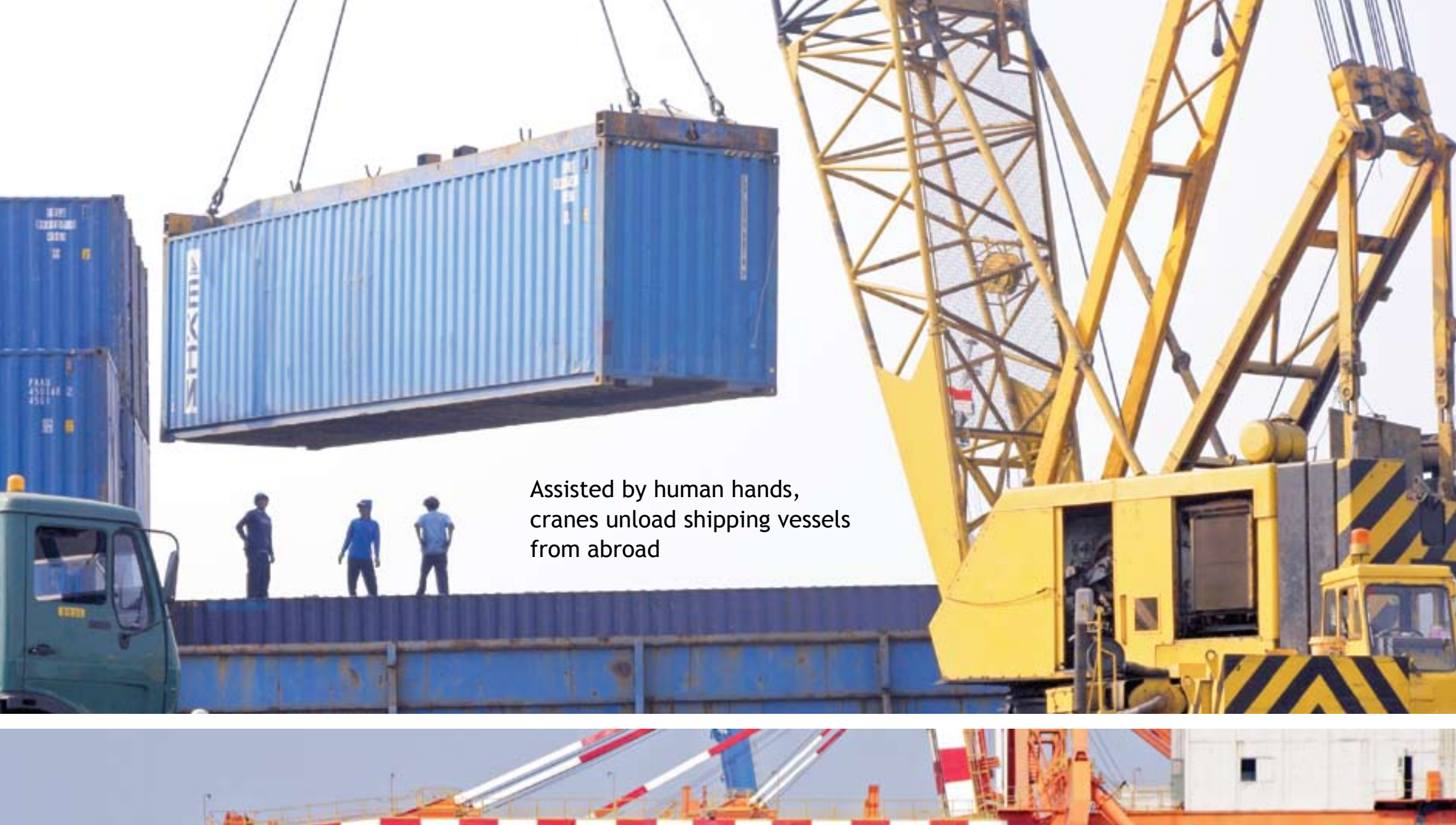
ready to load shipping vessels 
Tug boats sail past the quay, ready to assist giant shipping vessels out to sea

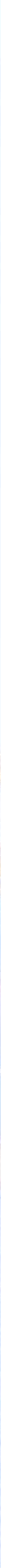


Tug boats prepare to guide a shipping vessel

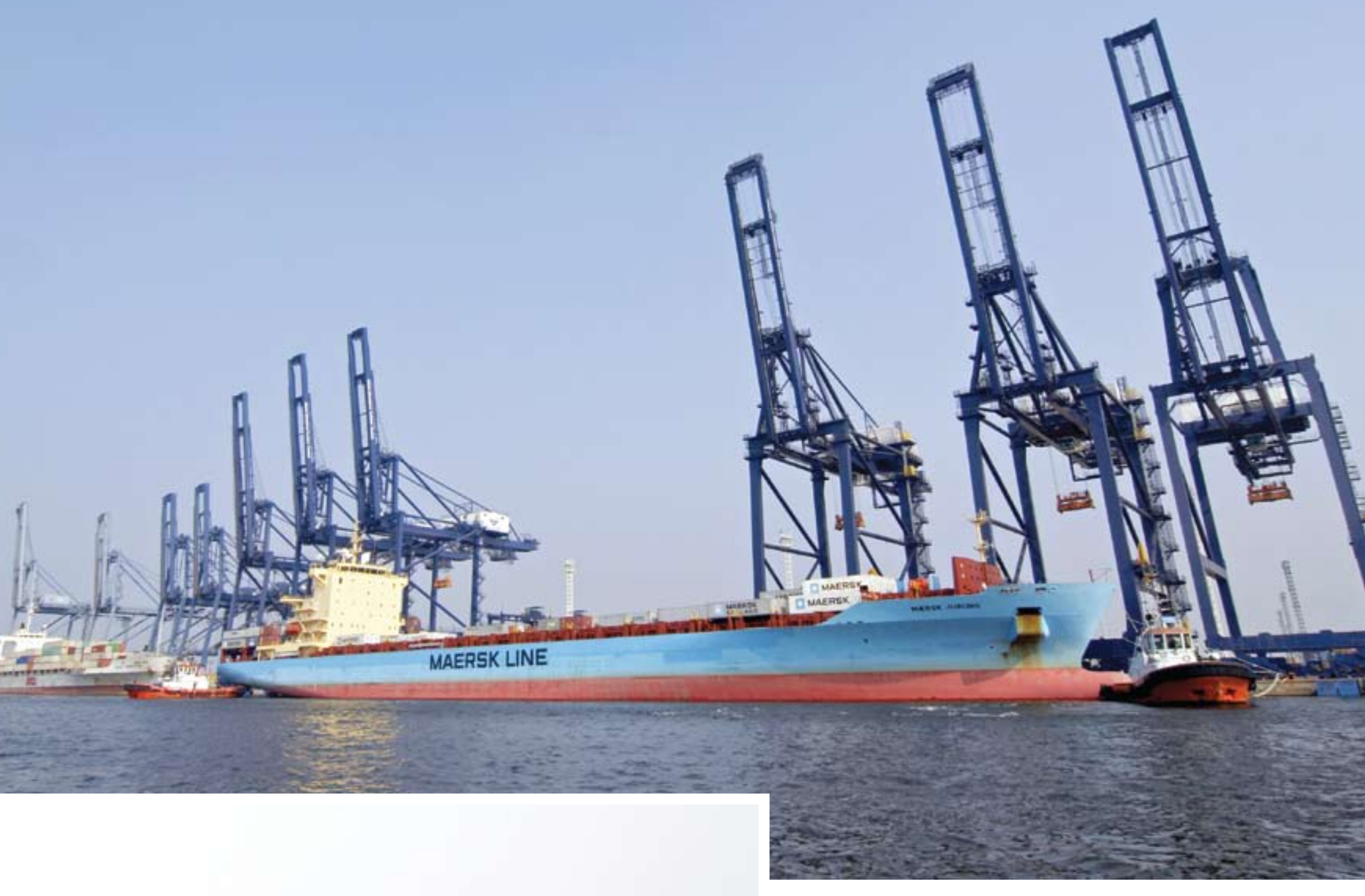

1

A second boat sits by the rear of the sailing vessel

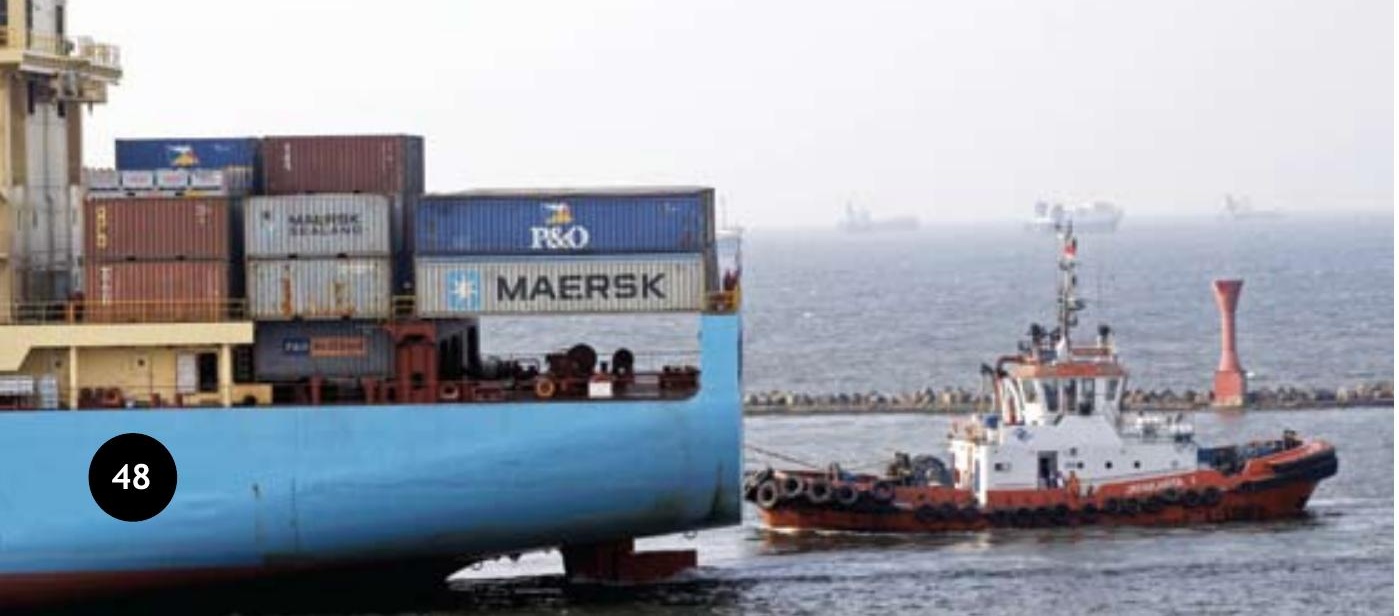


Completing its task, a tug boat leaves the ship to sail
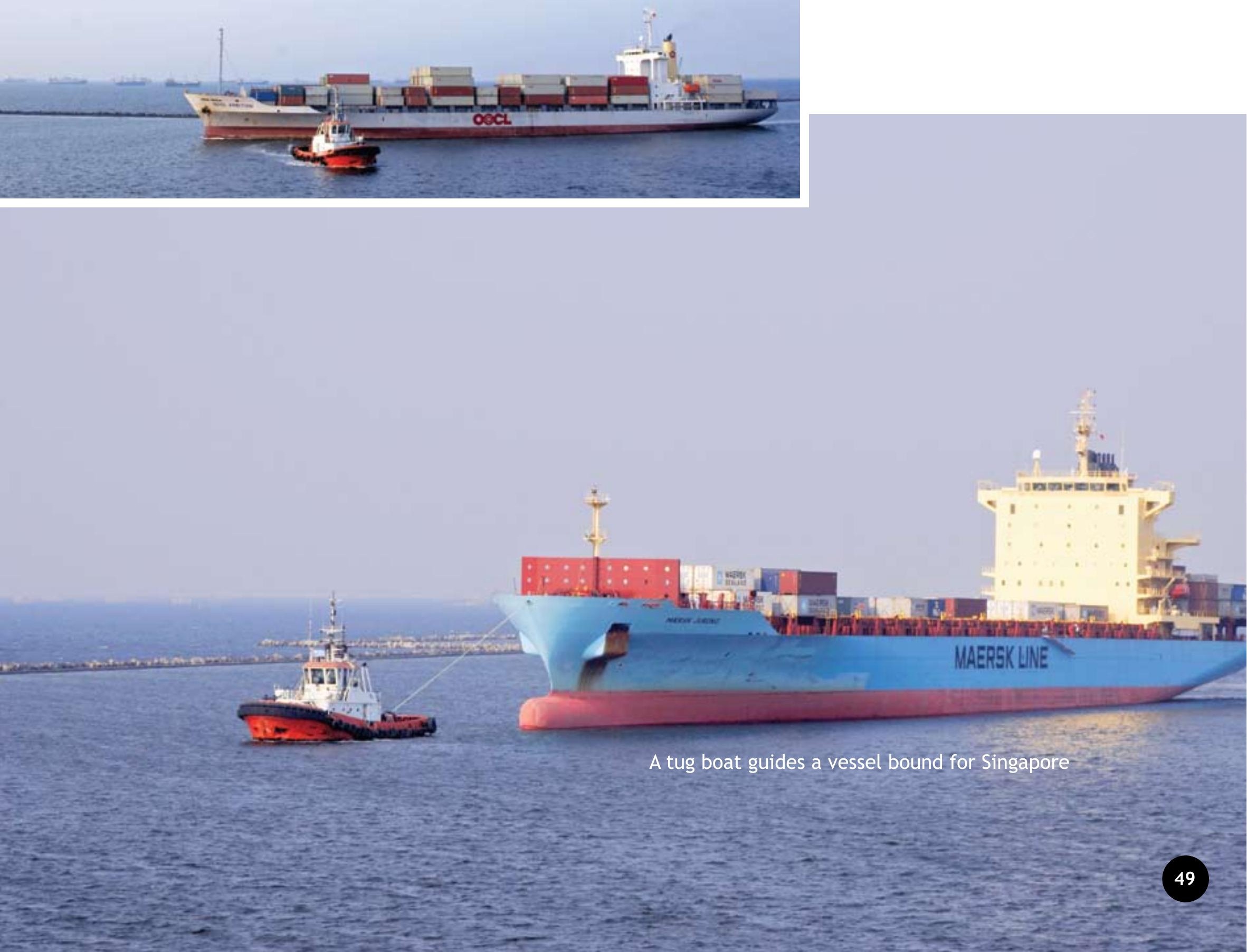


\section{$4-2+2 x=x$

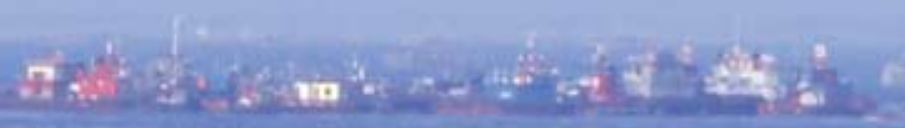

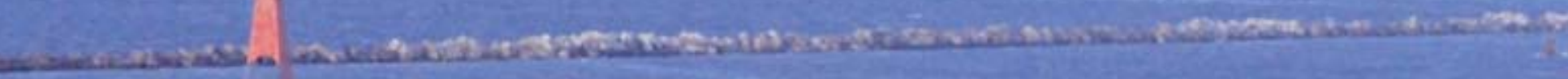

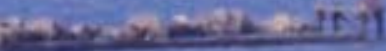

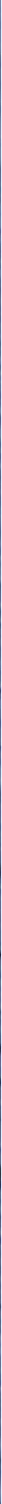




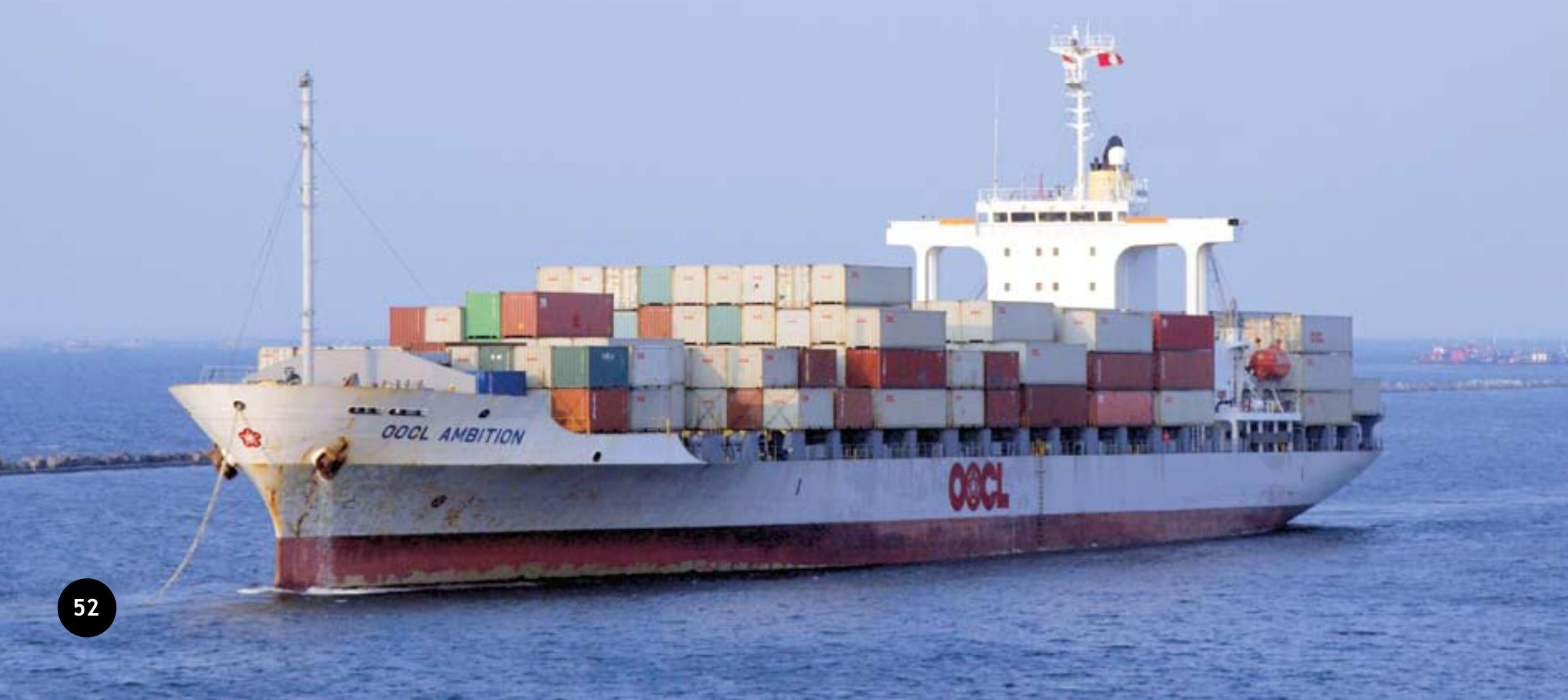




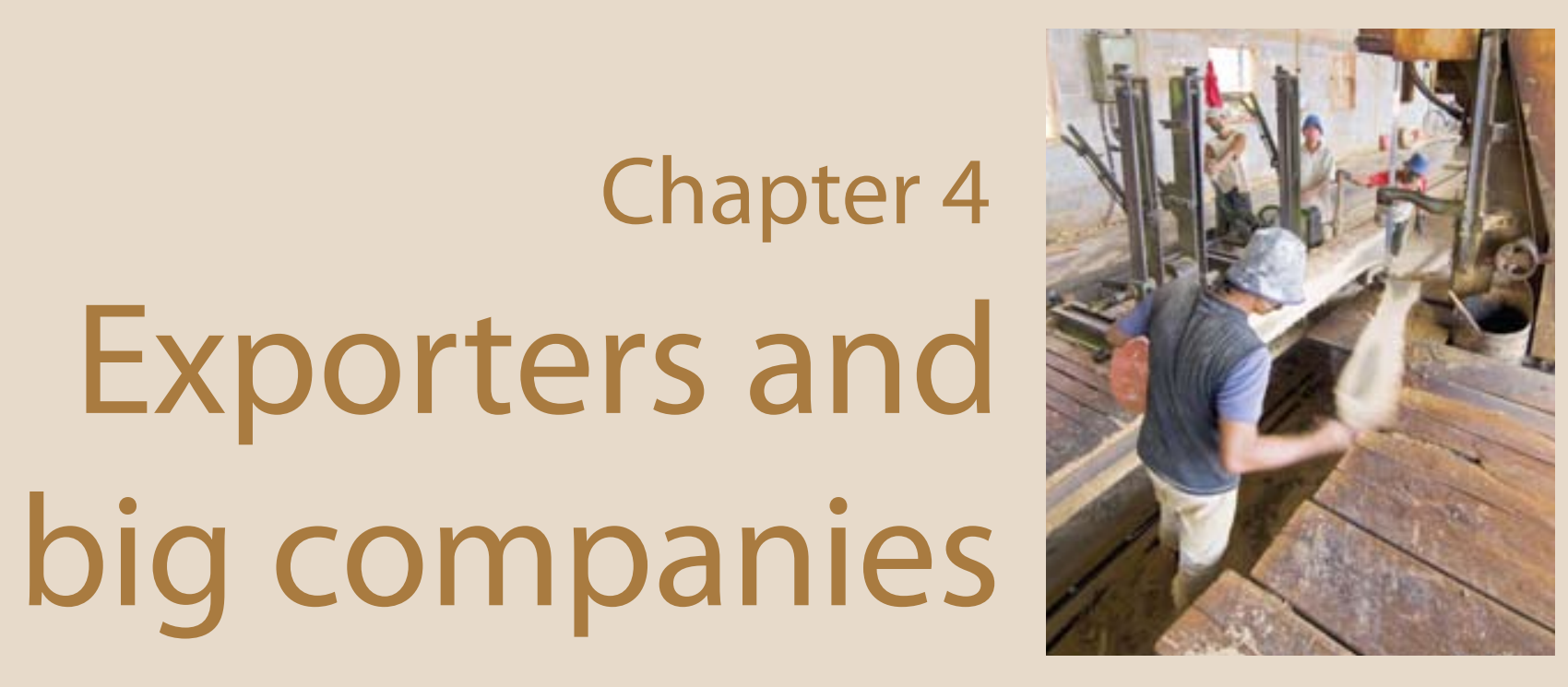




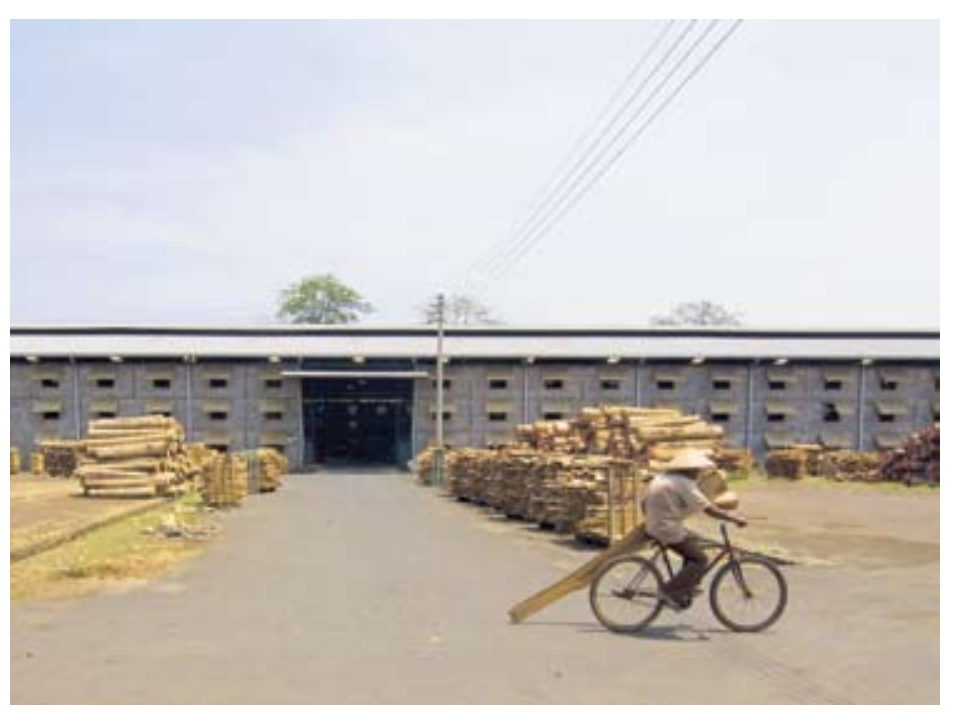

Taking cut wood by bike

\section{Exporters and big companies}

Exporters and large-scale companies generally obtain unfinished furniture from small-scale producers. They specify the products they will buy from these producers. Those specifications come from their buyers abroad. If the unfinished furniture fails to meet these specifications, the producers must fix the products before the exporters will accept them. These rules are set by the buyers, and they set the price. A producer can rarely negotiate on price unless they already have an established, long-term relationship with the buyer.

Other large-scale companies cooperate with fully integrated and mechanised furniture production enterprises. These producers have their own log yards and maintain timber stocks for at 


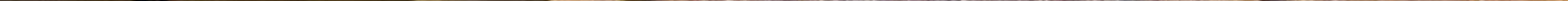




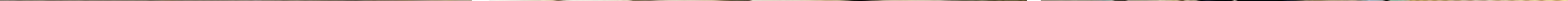


A woman sands a piece of

furniture at a big company

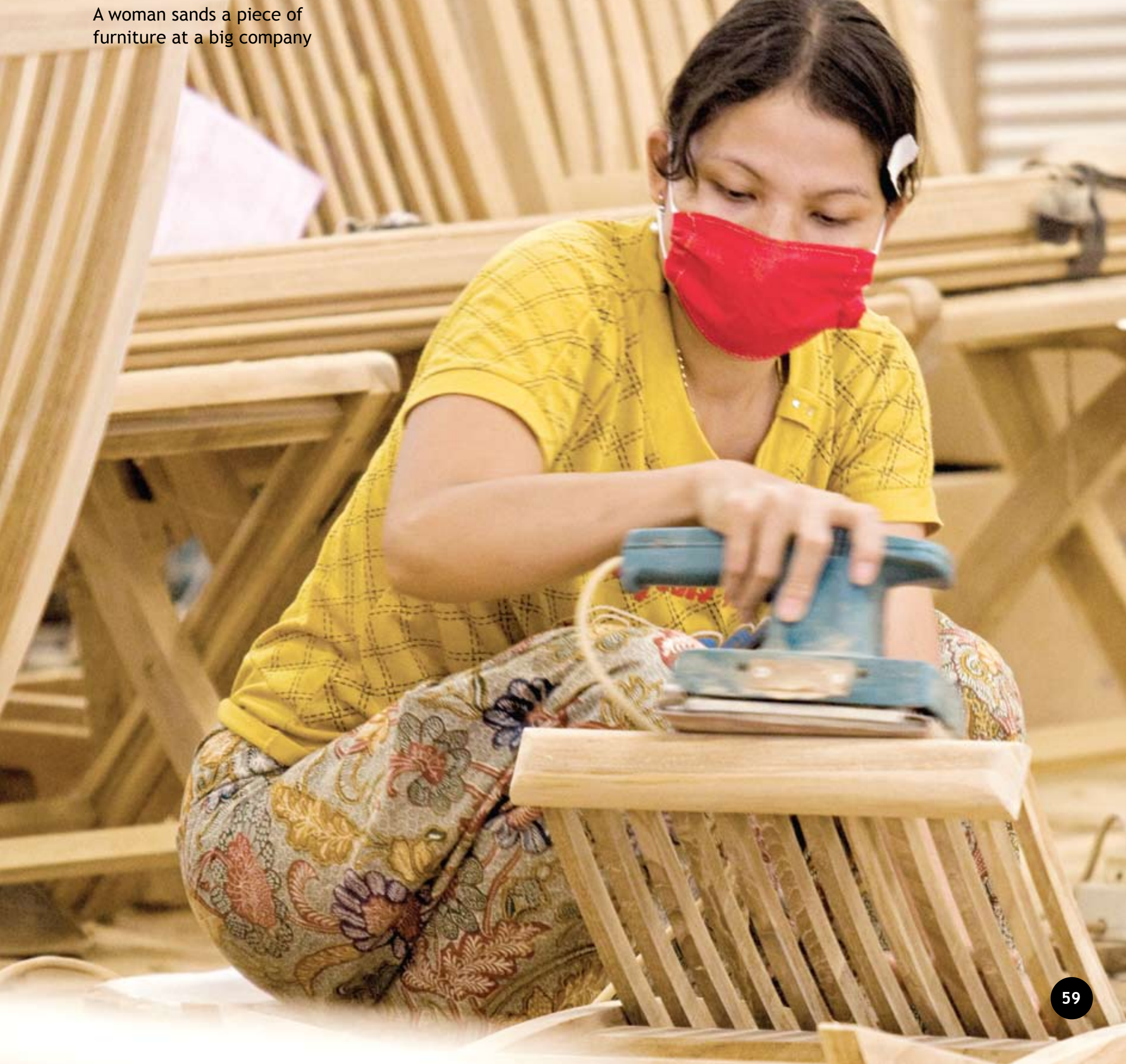






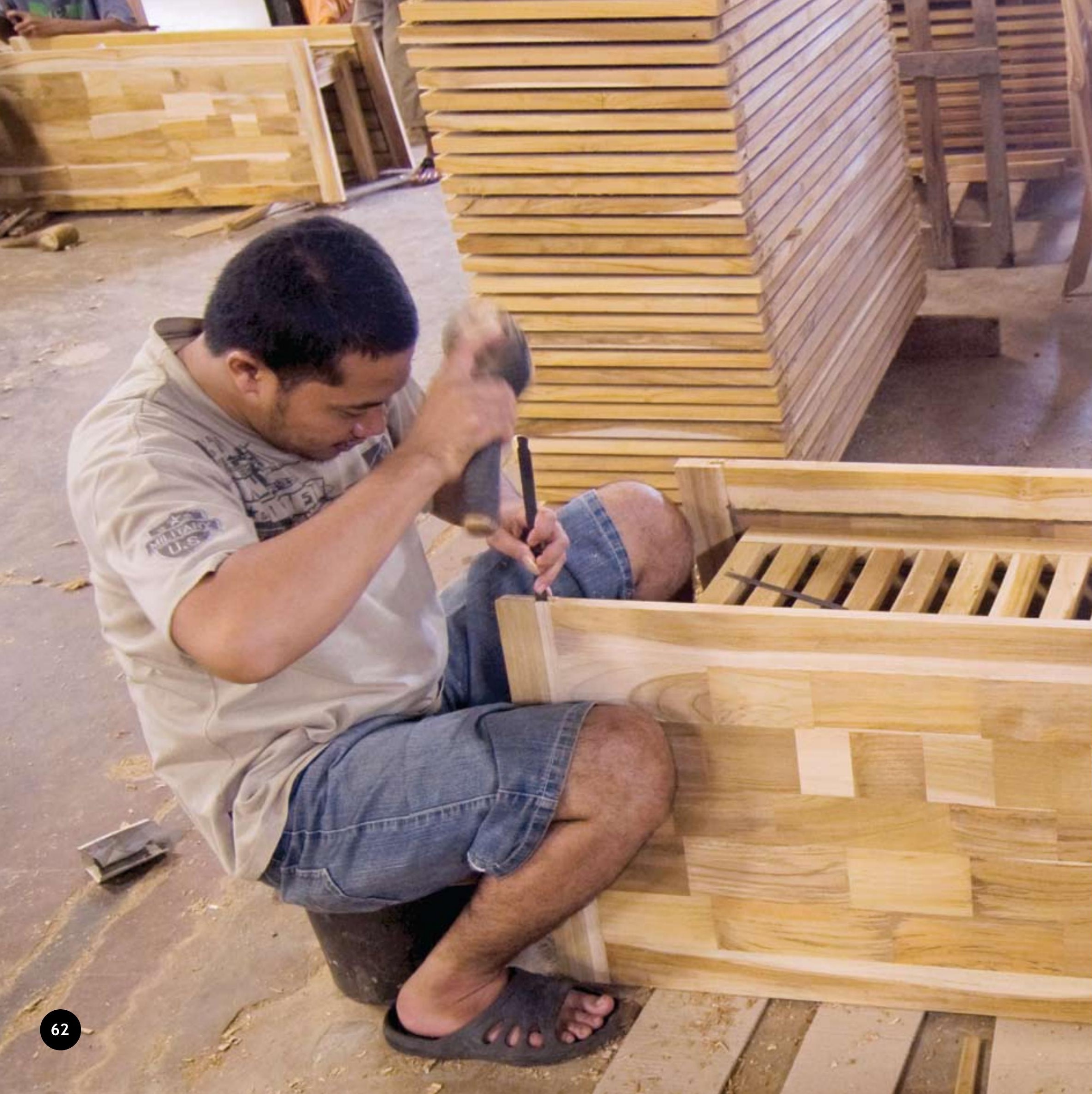




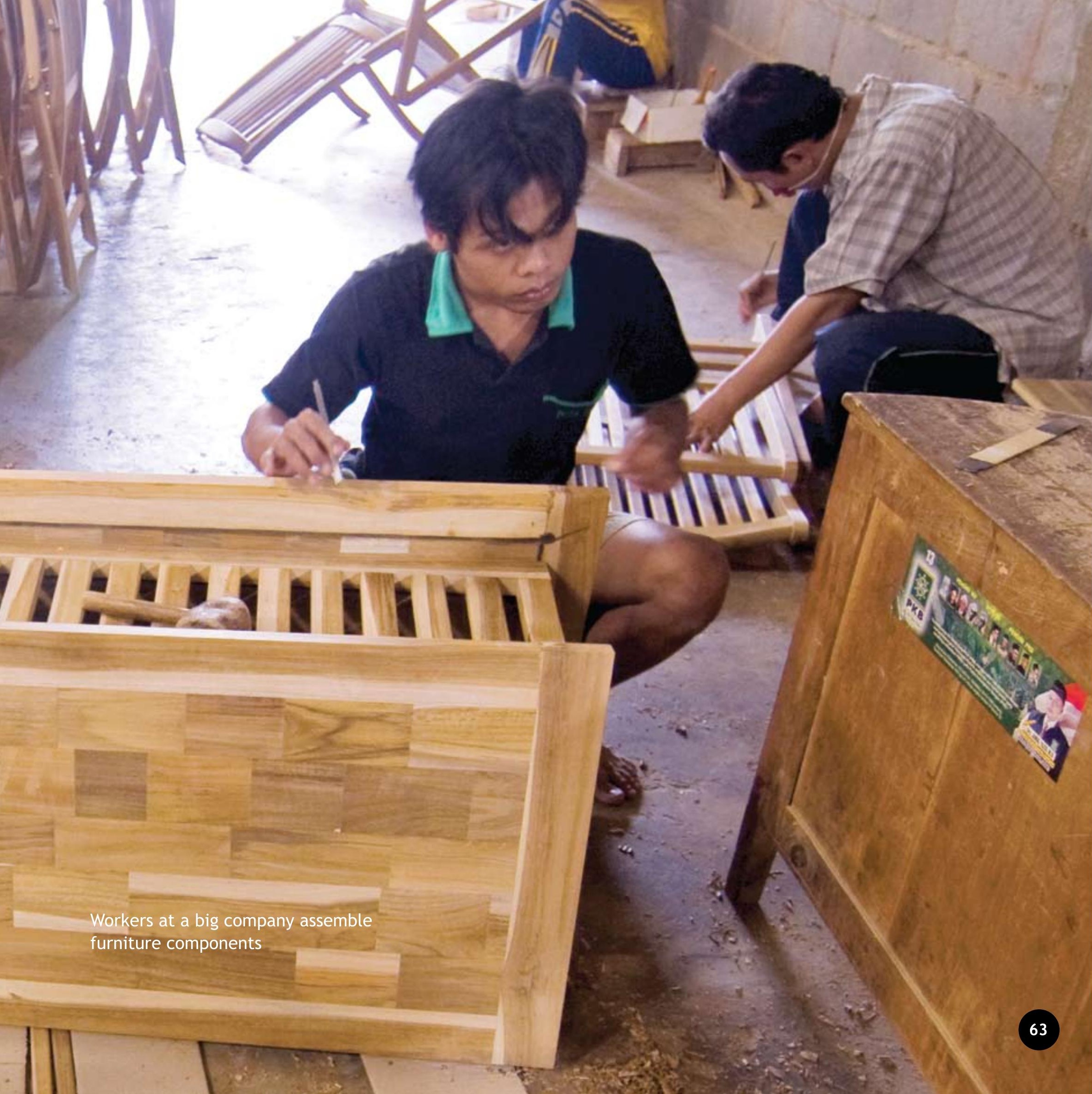




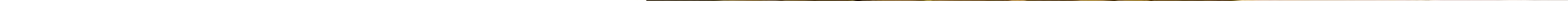




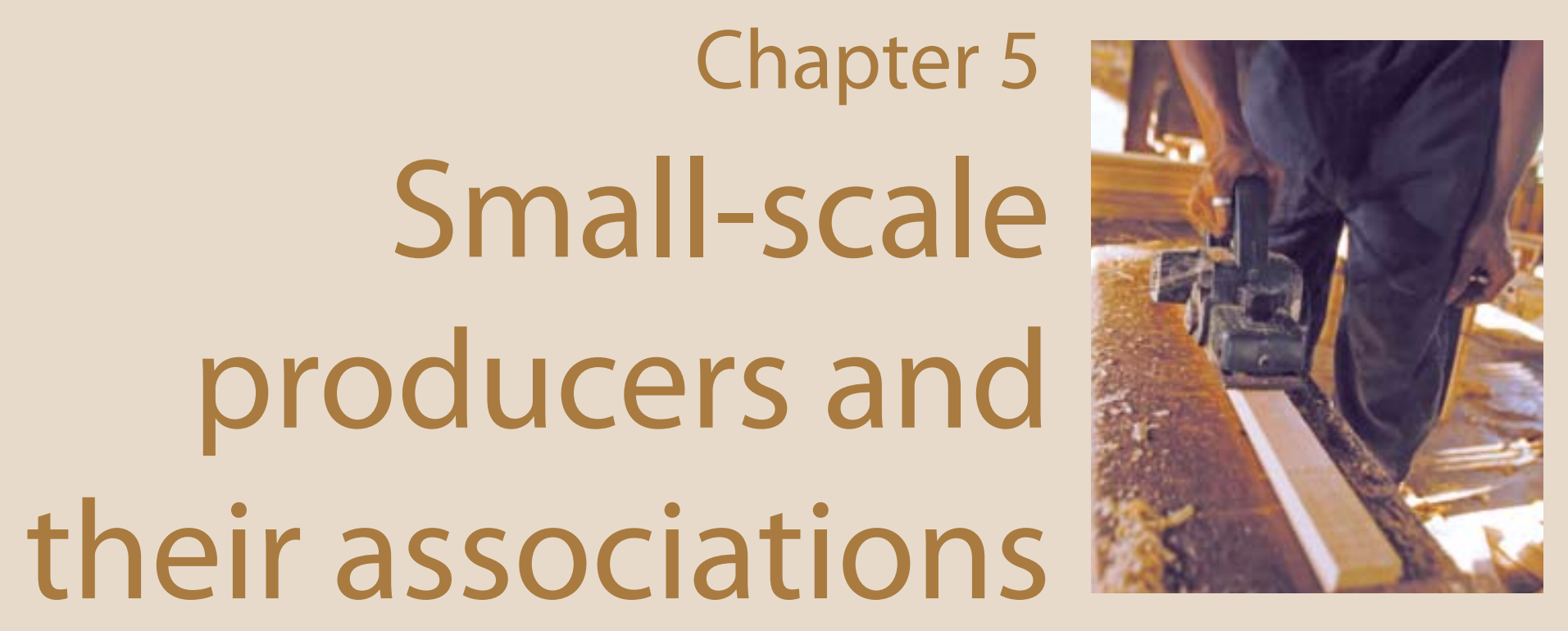




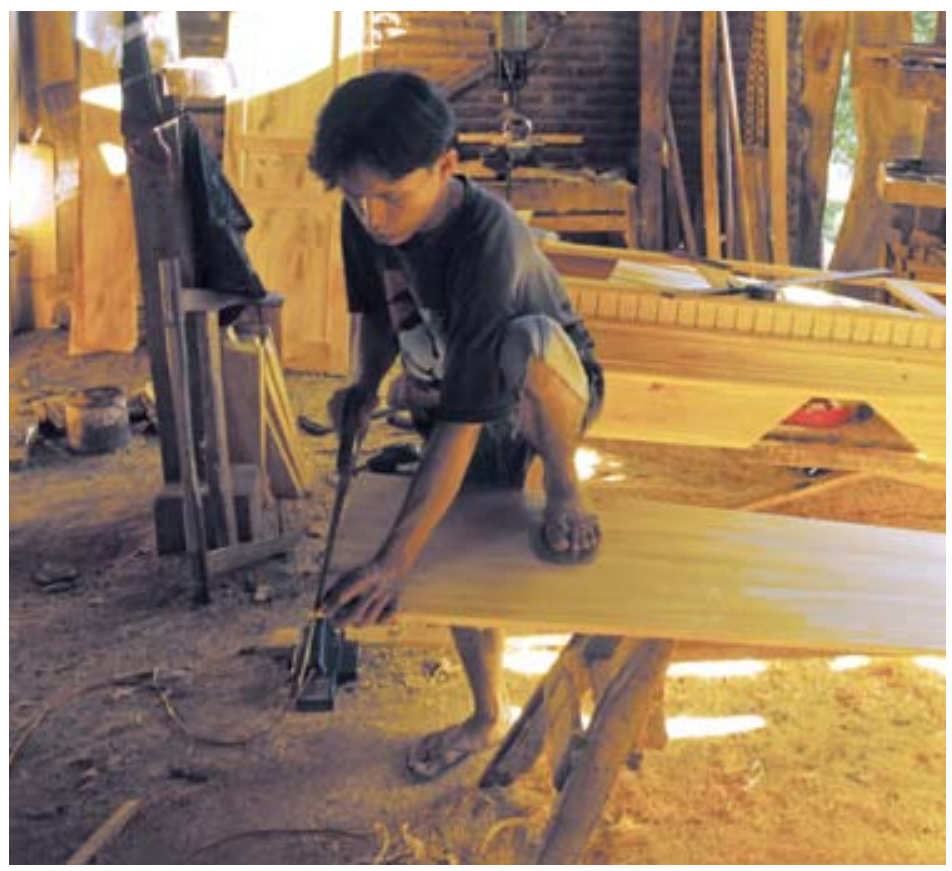

Sawing wood to make

furniture components

\section{Small-scale producers and their associations}

Small-scale furniture producers are the main actors in furniture production in Jepara. They choose the timber stock, make components, assemble them and supply the furniture ready for finishing to large-scale companies and exporters. They search for orders, and may be forced to take orders at prices insufficient to cover their production costs. Competition among small-scale producers is 
fierce. Some buyers take advantage of this situation and push down producers' profit margins.

Men usually do the heavy work of making components and assembling the furniture. Women do the lighter jobs in finishing such as sanding the raw furniture products as they are deemed tidier and more patient. Men are generally paid more than women.

The approximately 15000 small-scale furniture producers in Jepara needed an association capable of improving their decision-making authority within the range of governance systems and serve as a forum through which they could share their problems. The Small-scale Furniture Producers Association in Jepara APKJ was established in December 2008. The group aims to improve small-scale furniture producers` capacity to function independently and be competitive in the global market, to empower the members of APKJ to advance the prosperity of the Jepara furniture industry. The association plans to improve small-scale furniture producers' skills for a better bargaining position, to create fair market prices and to facilitate access to credit. APKJ also plans to address the main challenges furniture producers face in marketing, raw materials, access to capital and human resources. 


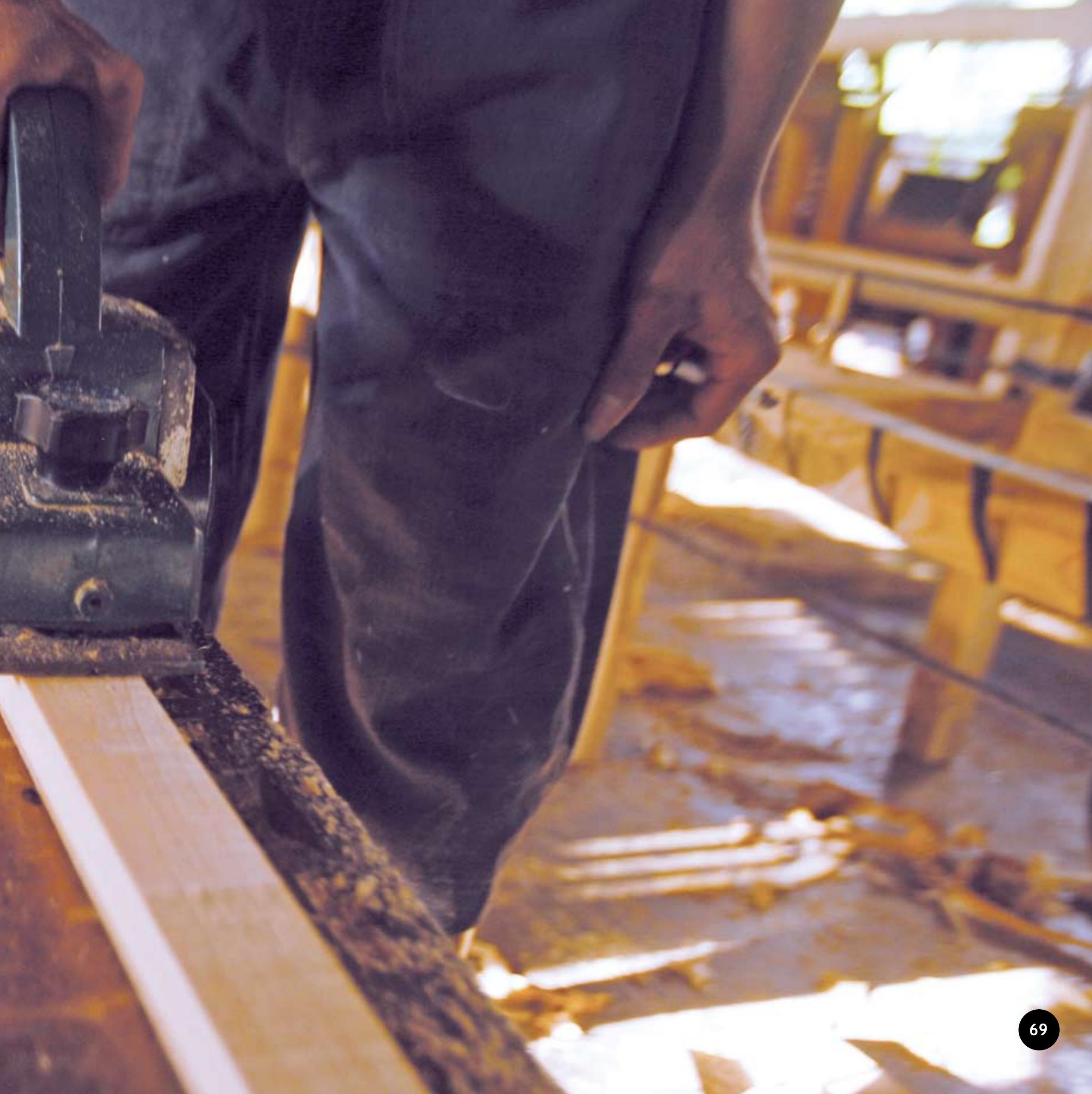




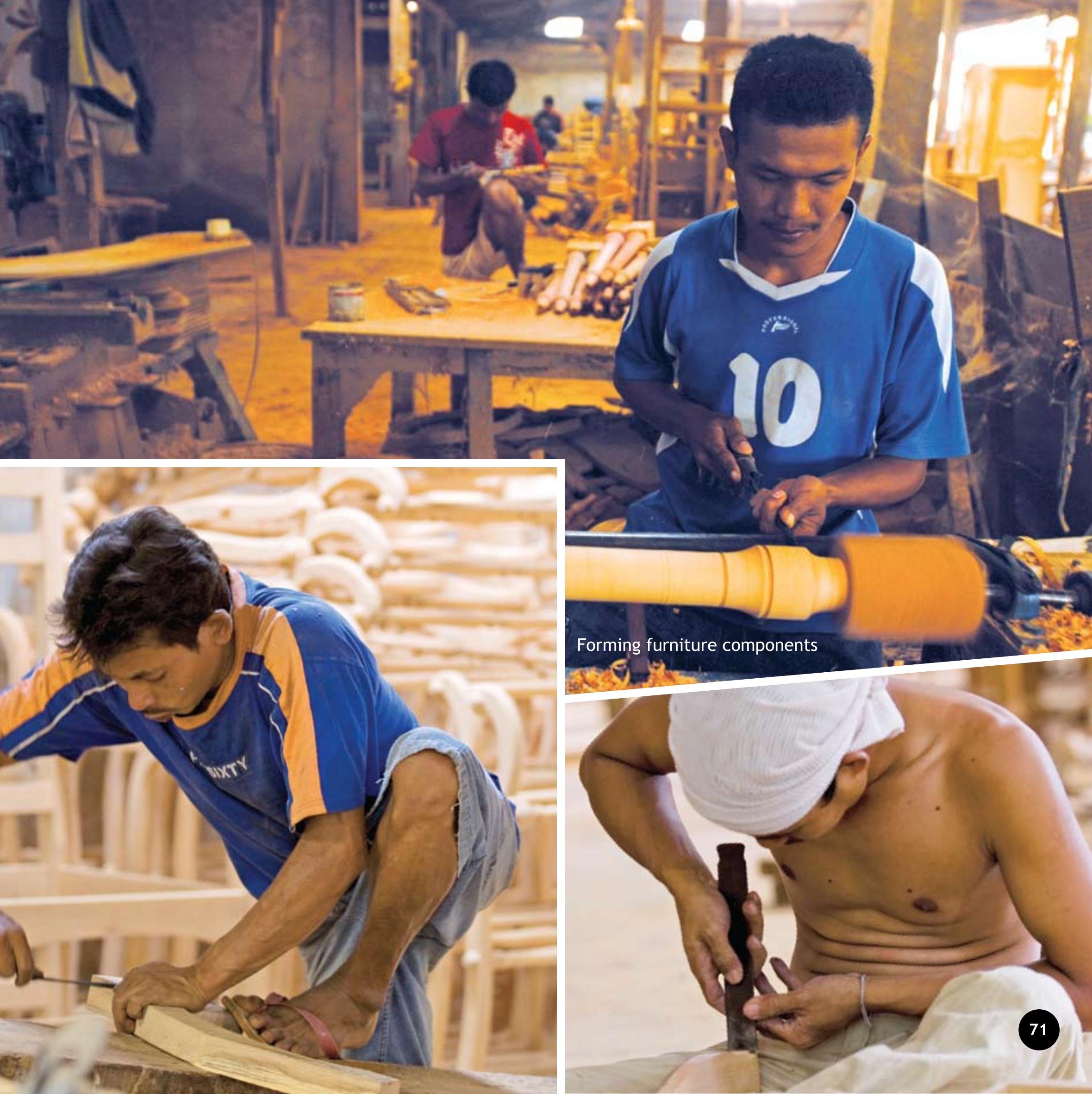




\section{Tracing carving patterns}

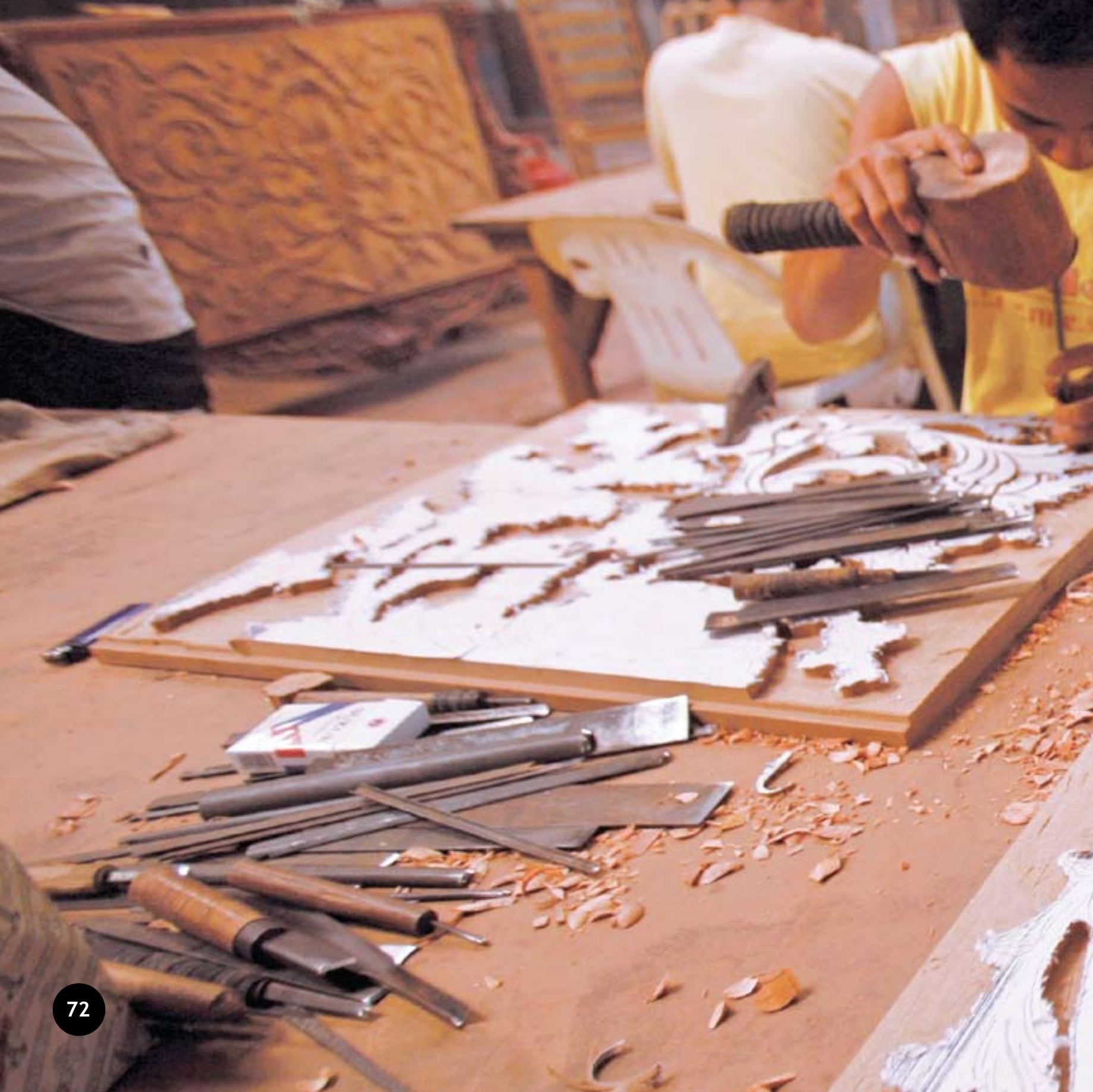




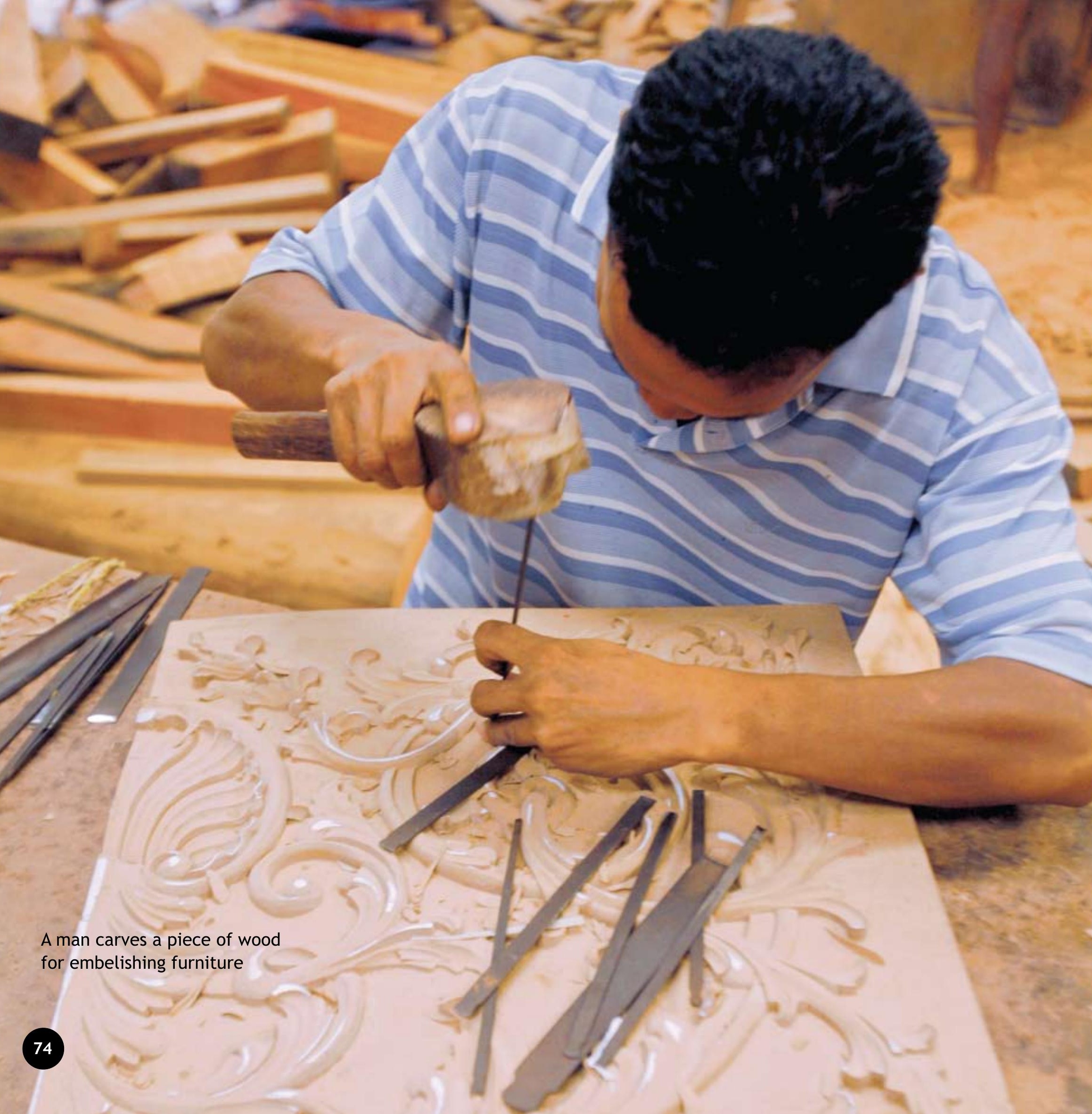




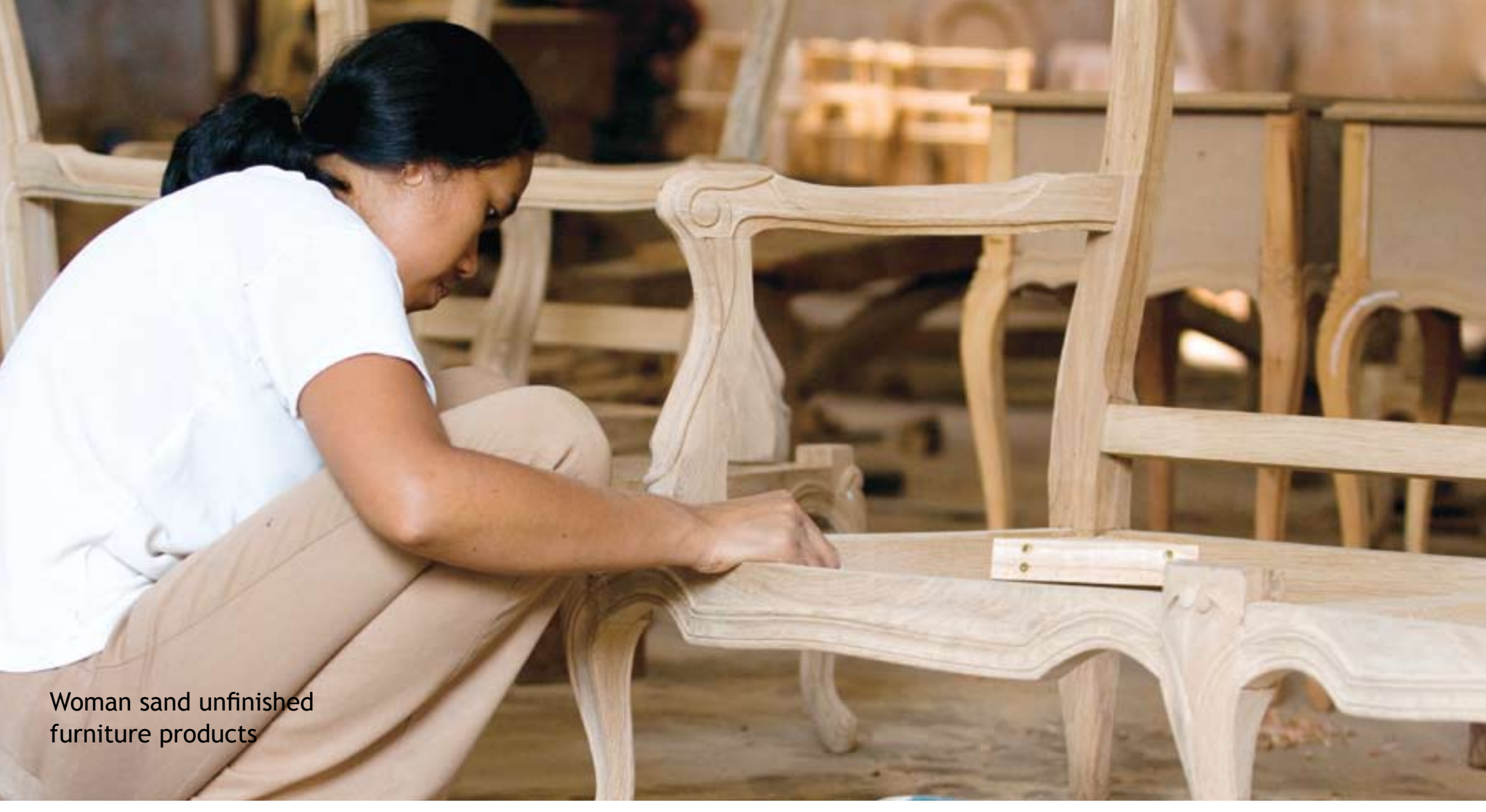

\section{Dif}

he
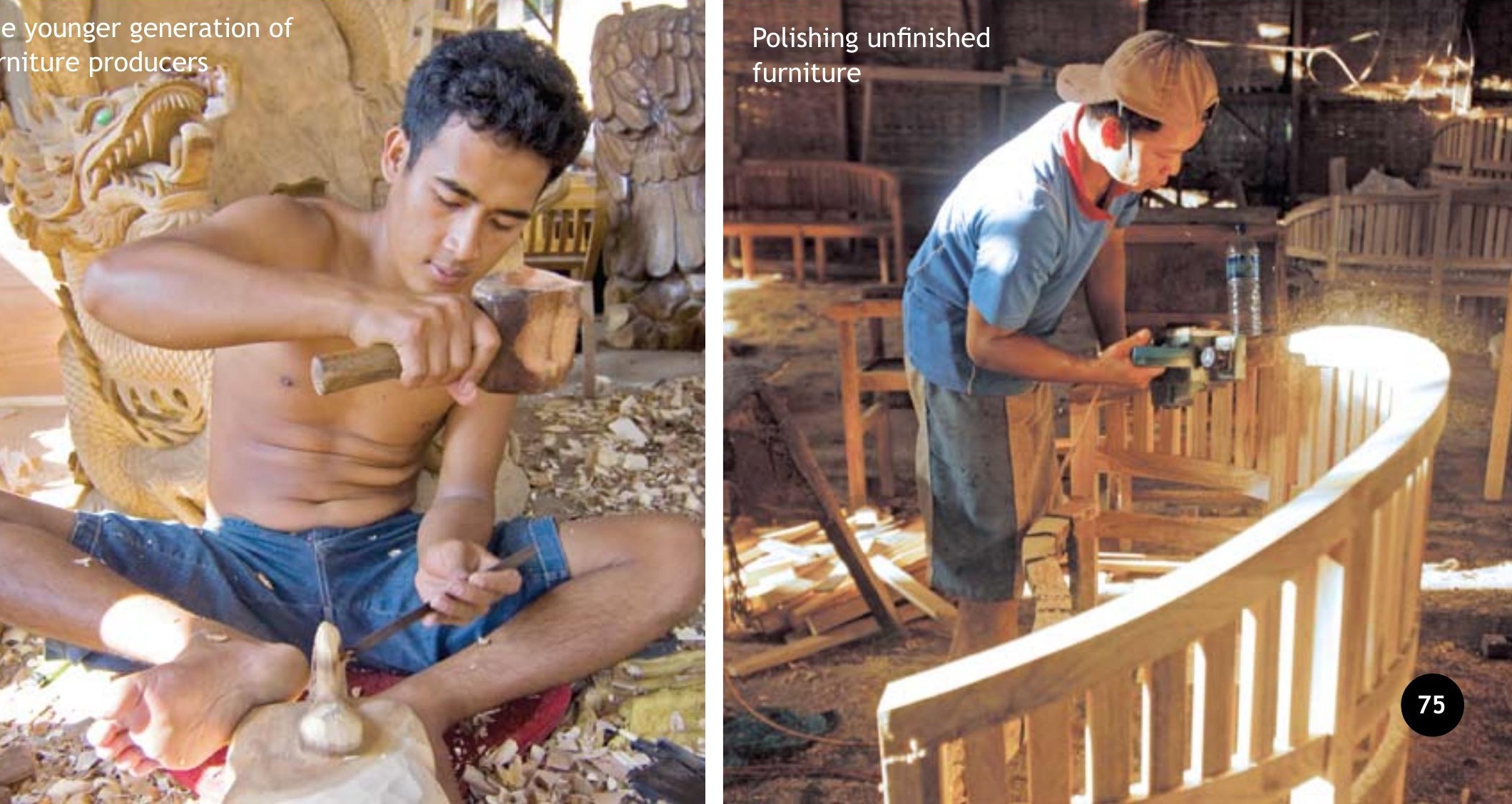


\section{- an}

Women sand unfinished products for export
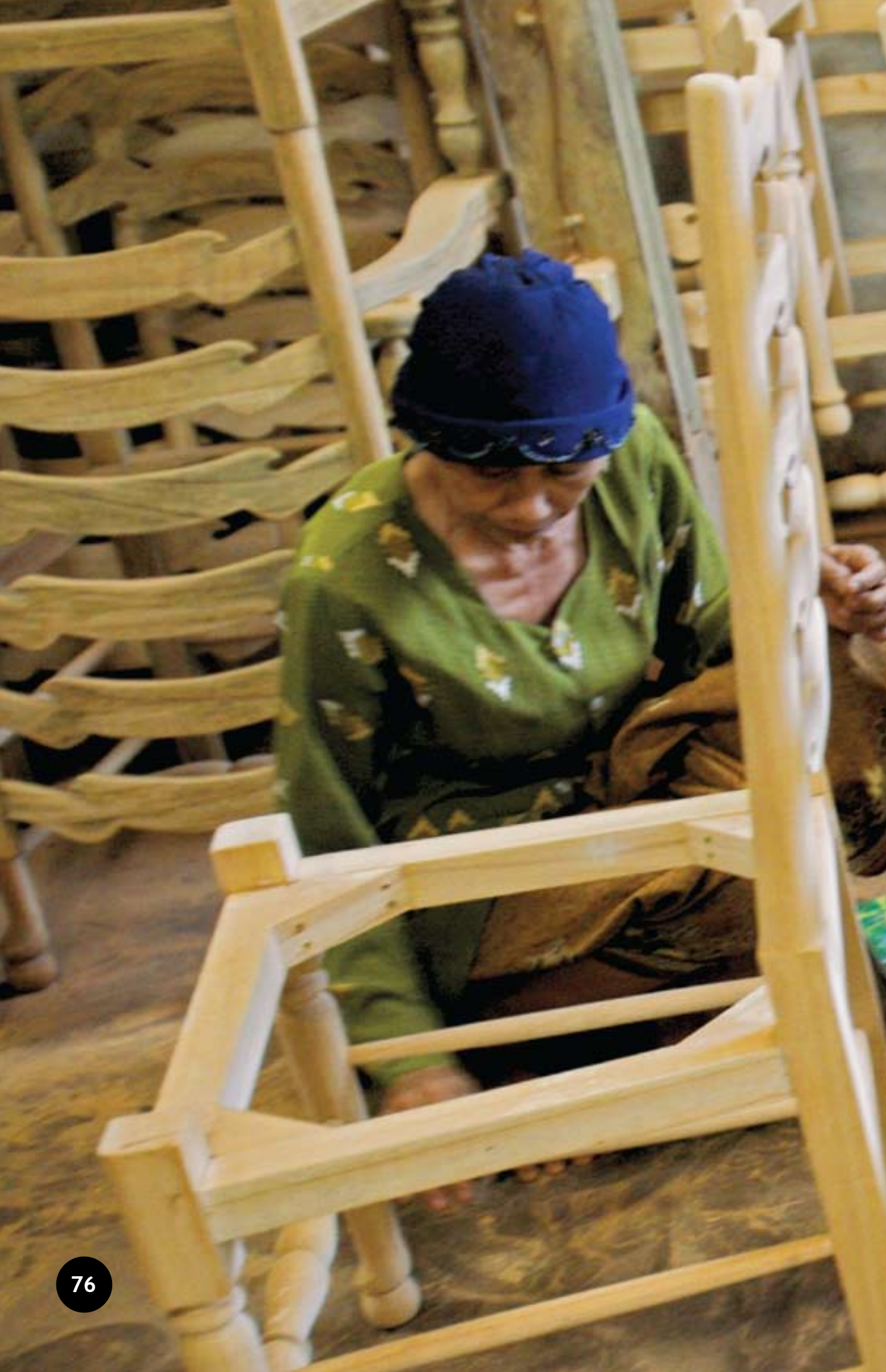


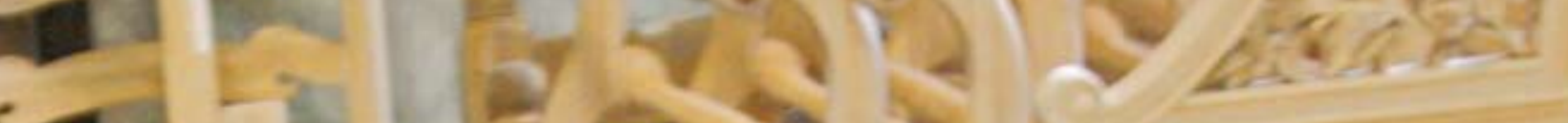

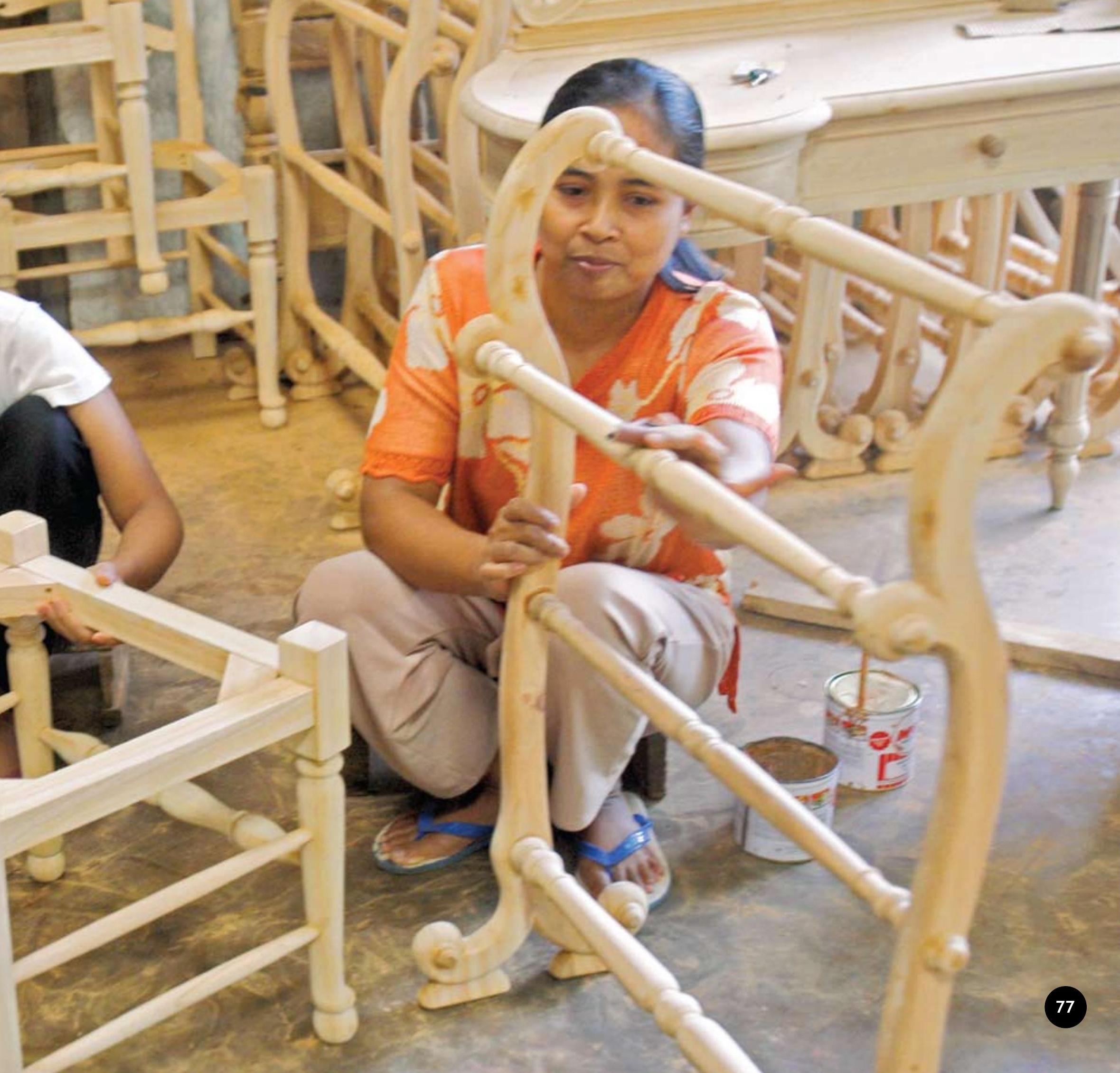




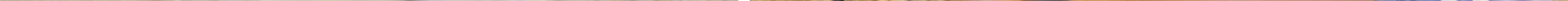


A woman sands unfinished

furniture products
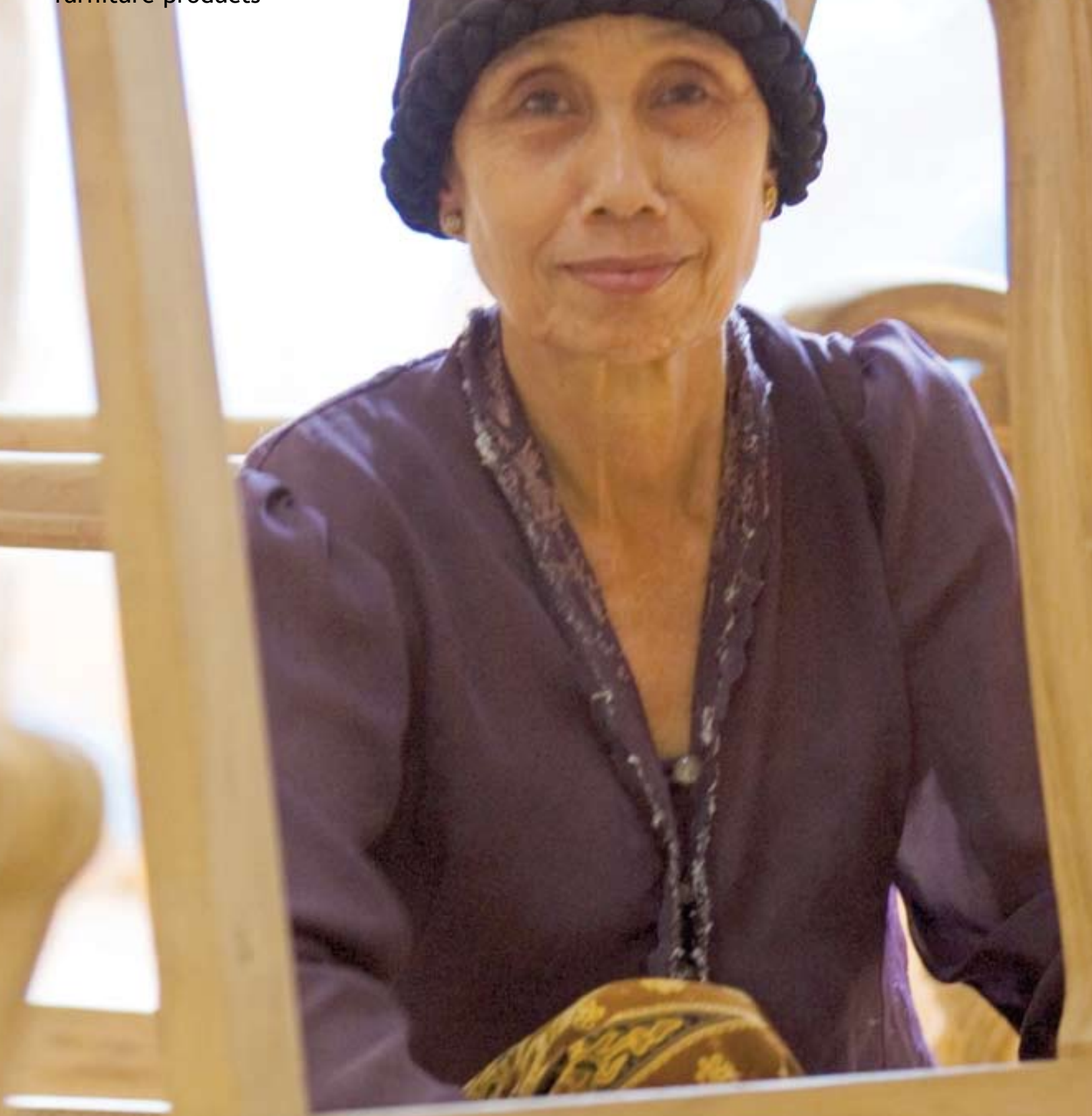


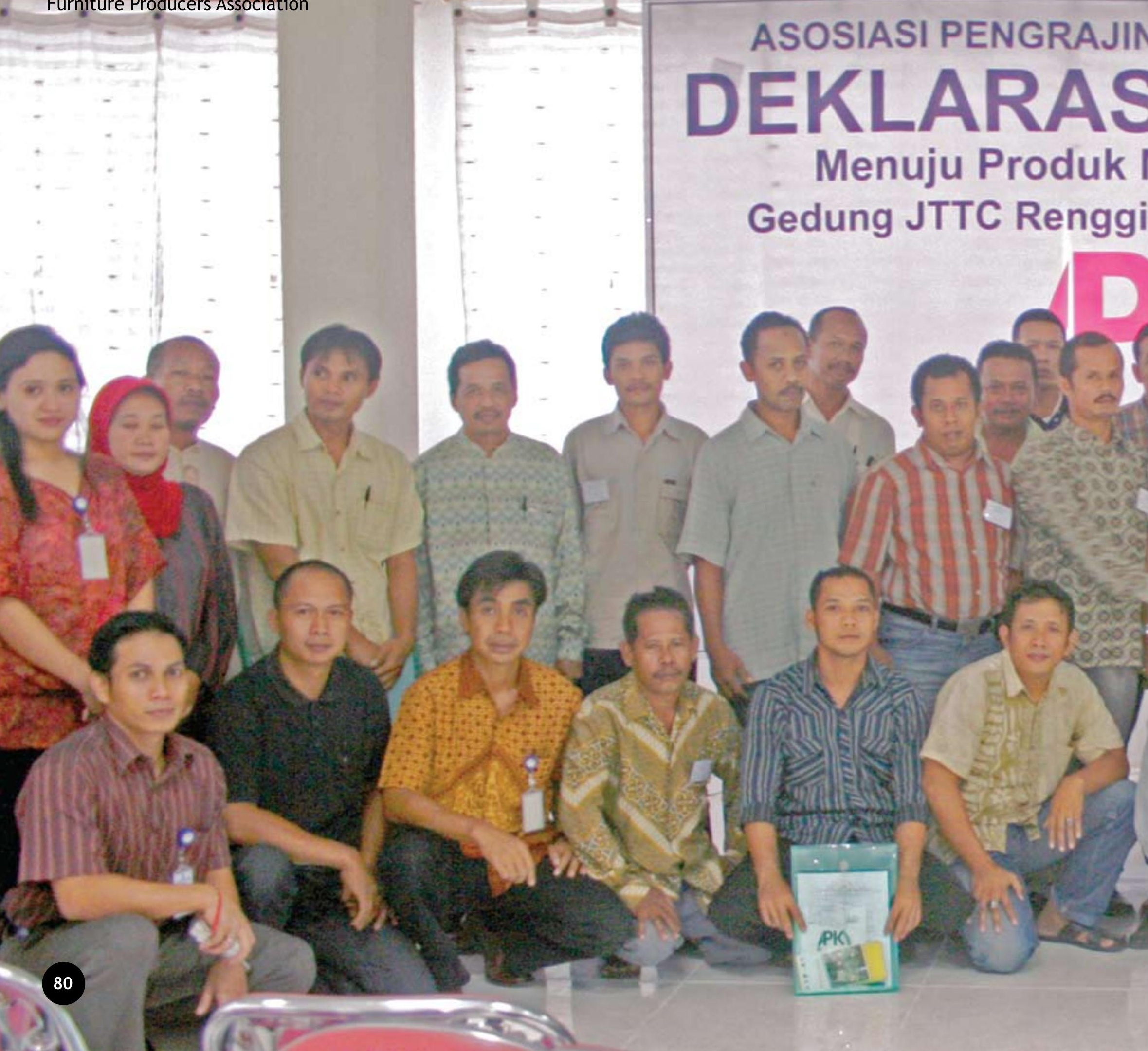



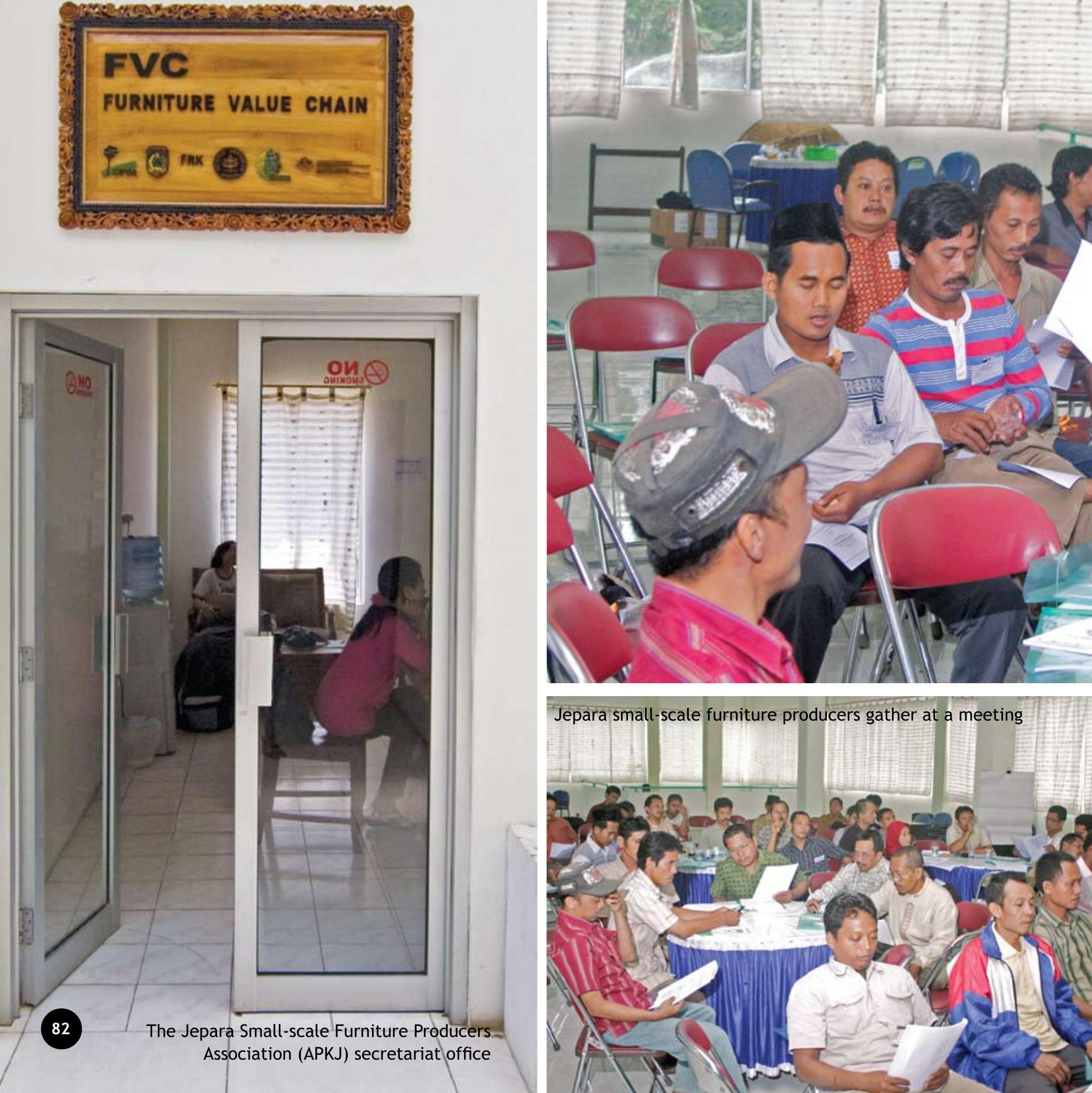

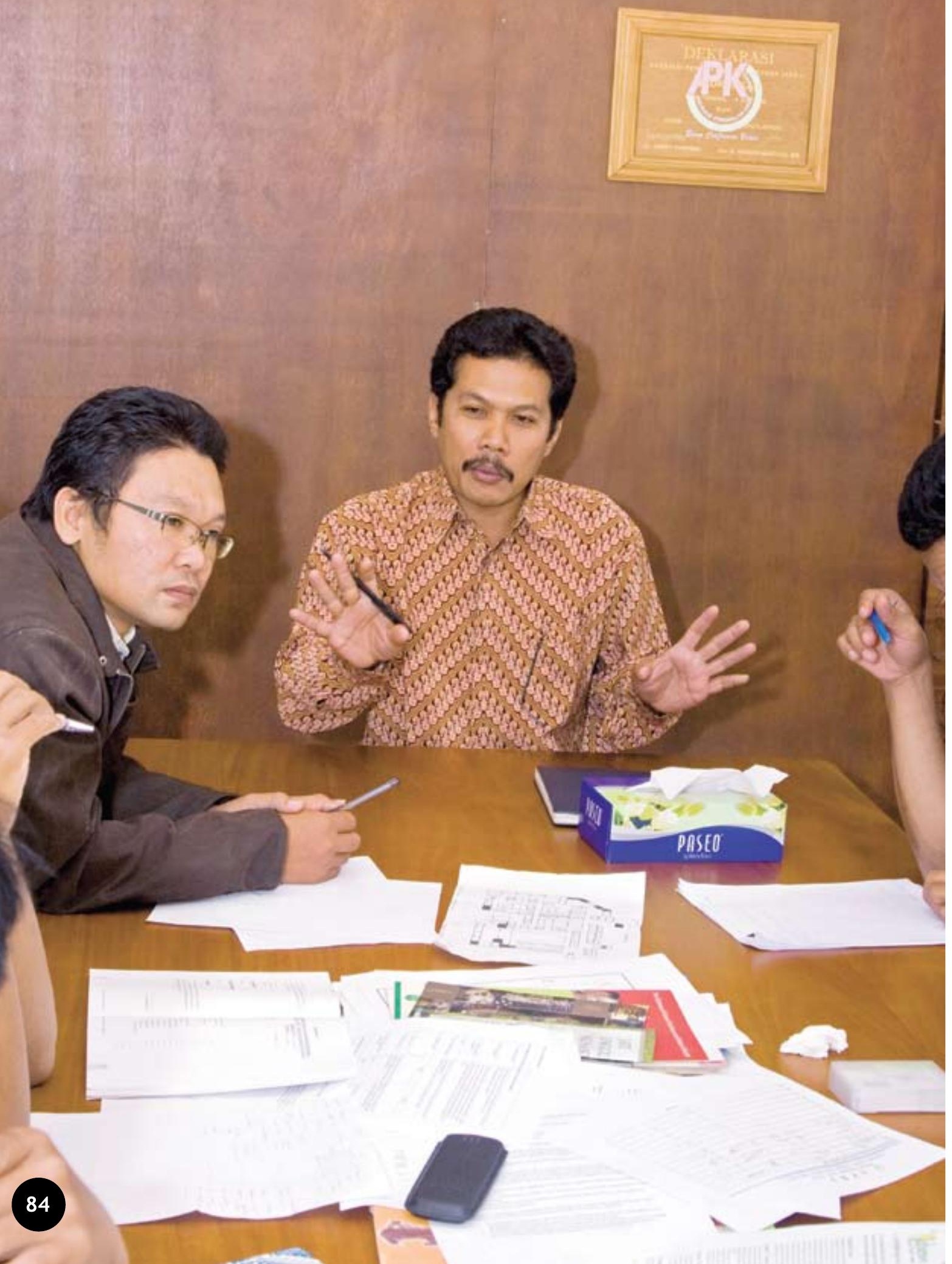

The APKJ chairman shares his thoughts on exhibition plans 


\section{Akot Nurputro}

Teak garden

table producer

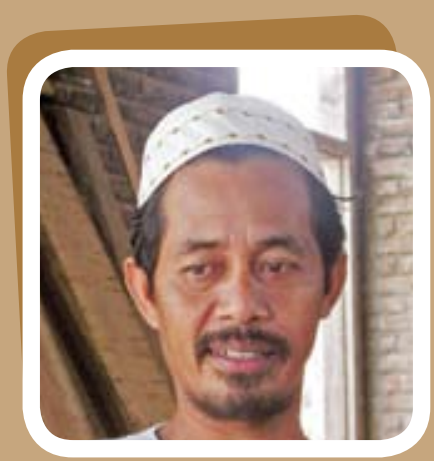

Asrofi

Indoor teak

furniture producer
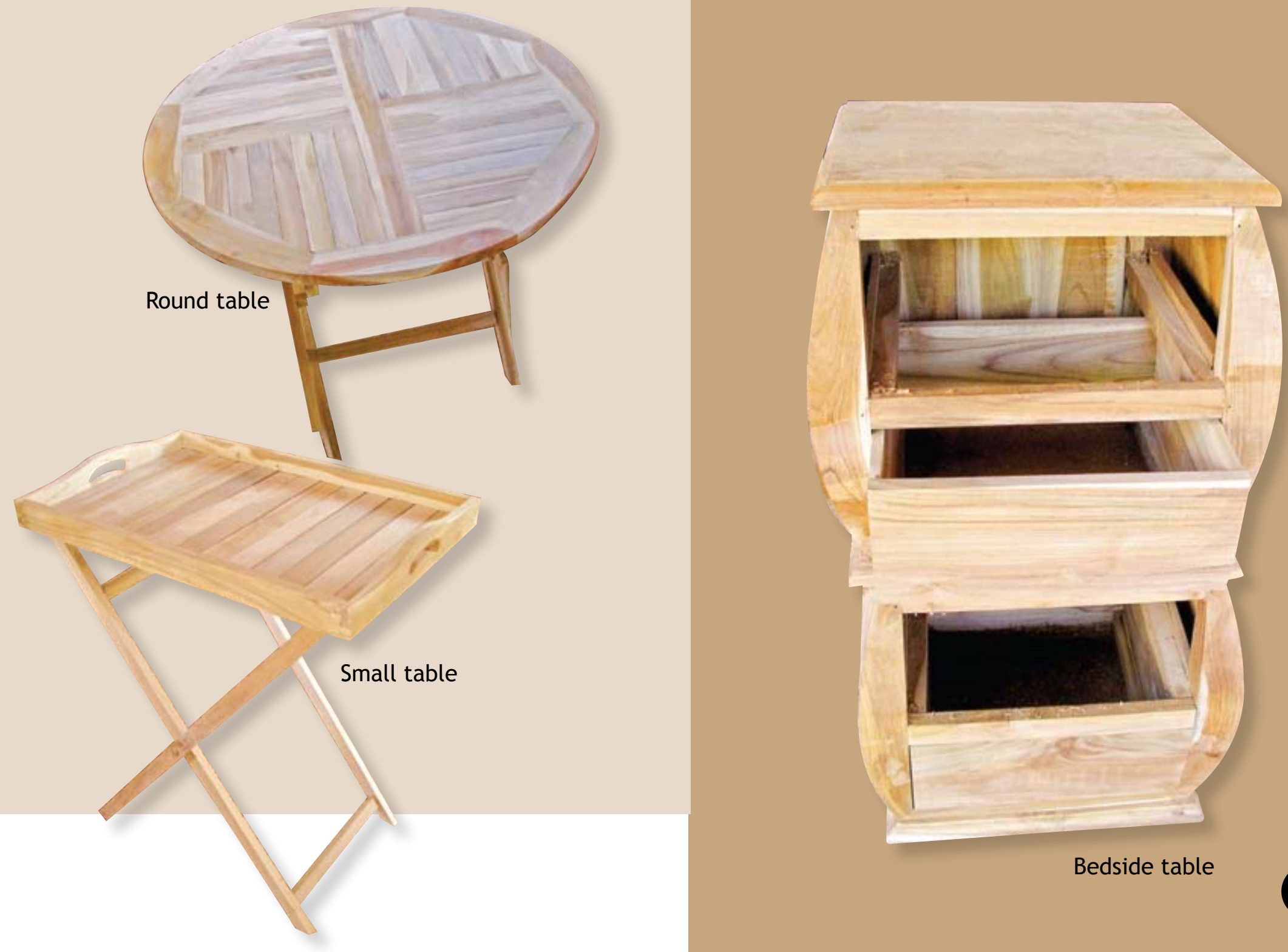

Bedside table 


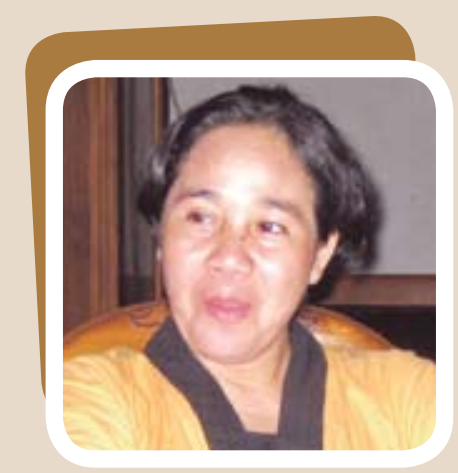

\section{Zumaroh}

Indoor teak furniture producer
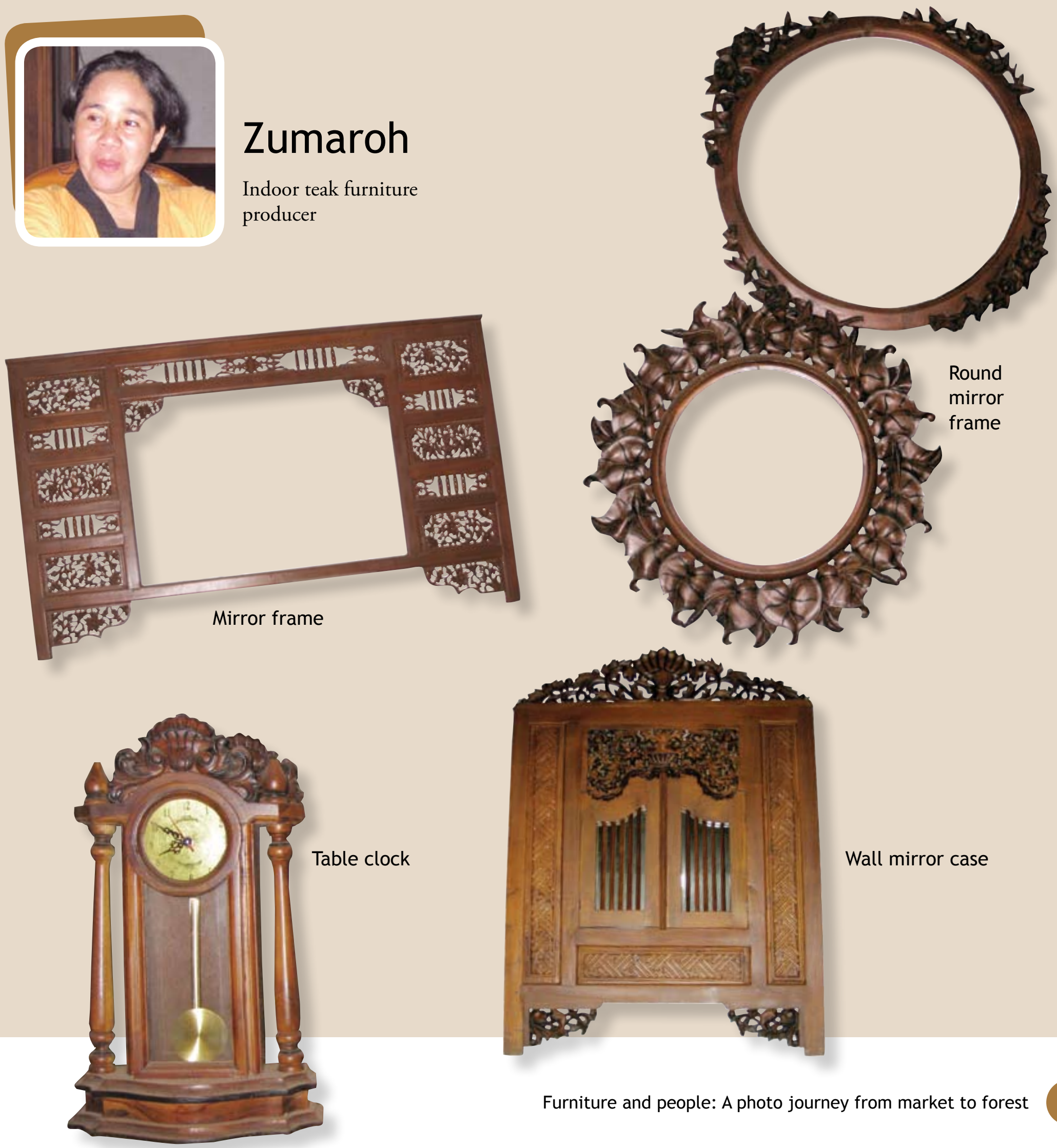

Wall mirror case

Furniture and people: A photo journey from market to forest 


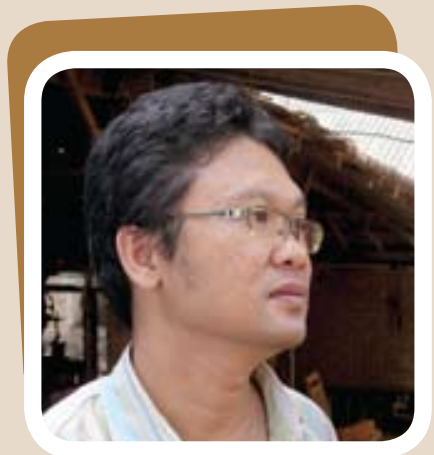

Mohamad Hatta
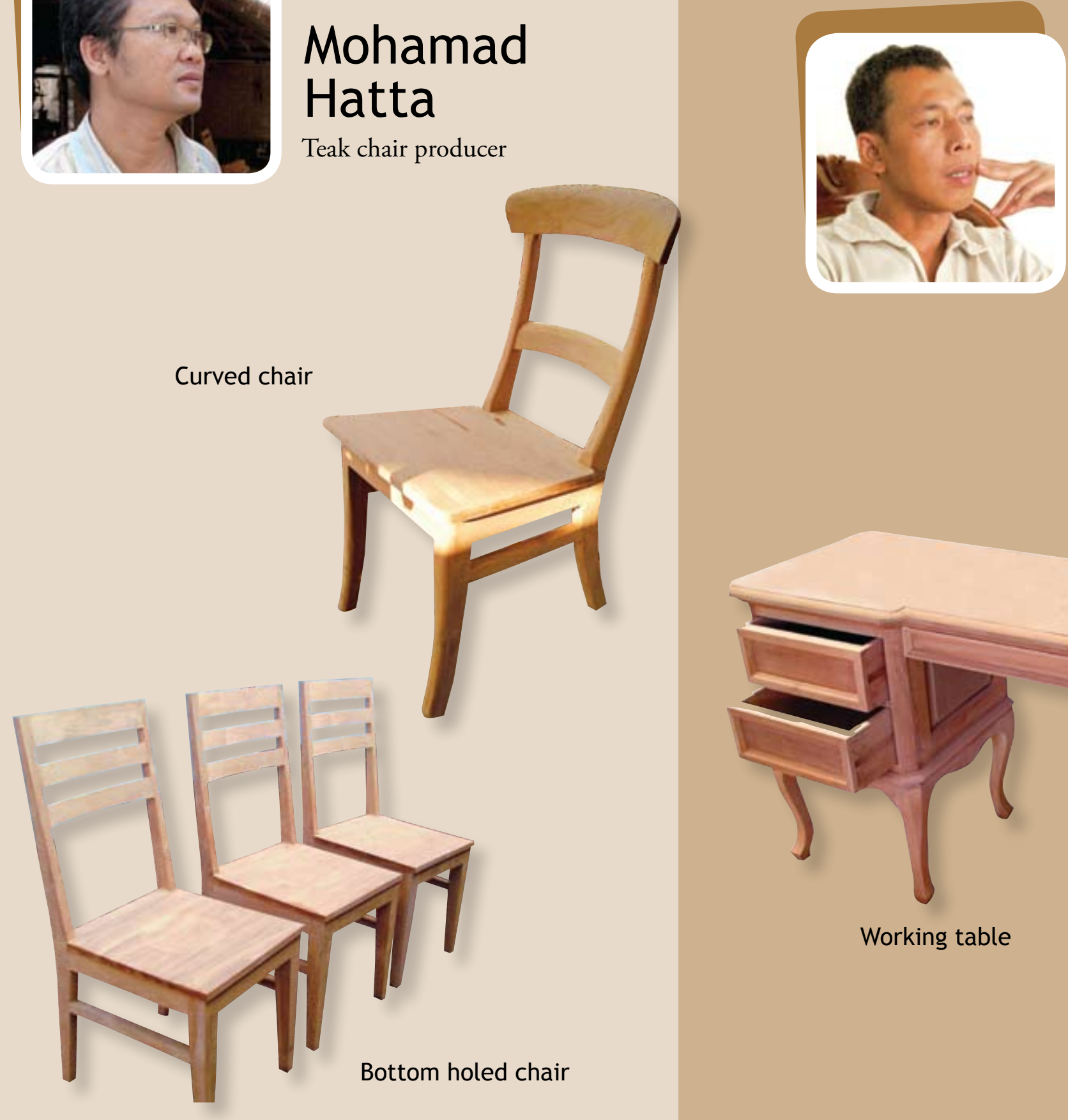

\section{Sugiyanto}

Indoor mahogany

furniture producer

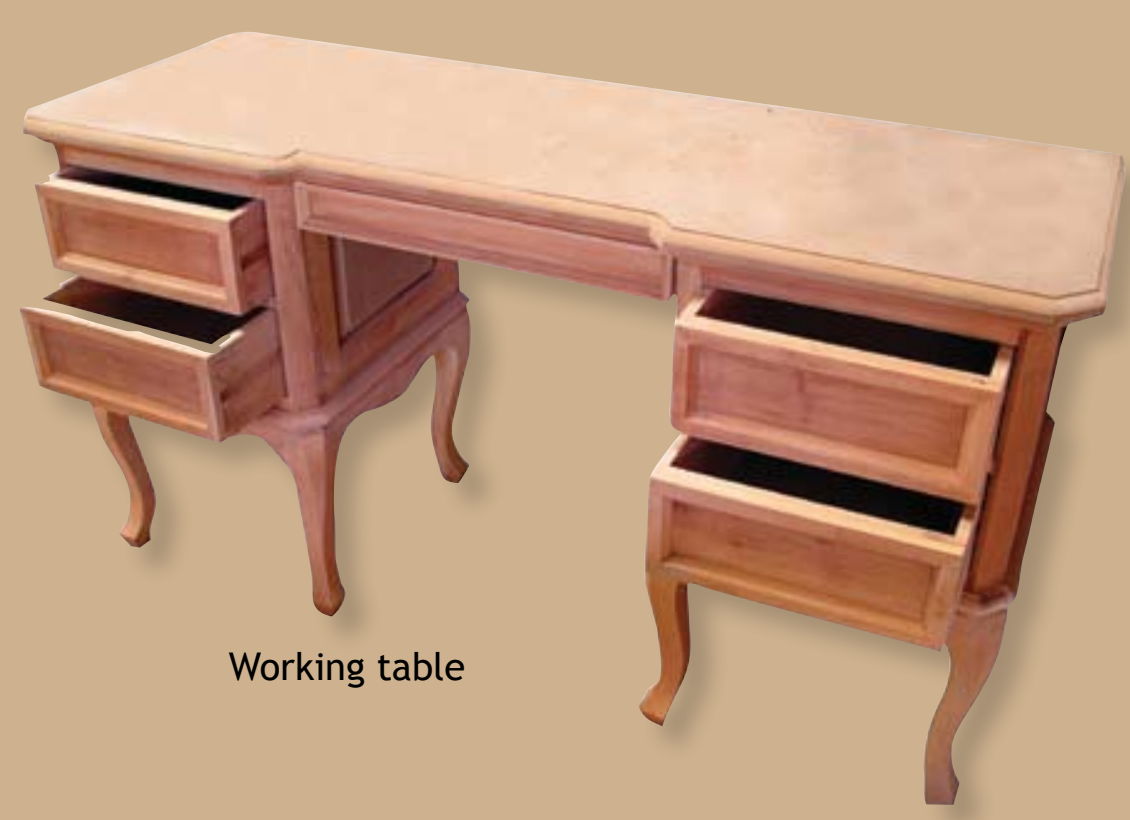




\section{Nurhamid}

Indoor and outdoor teak

furniture producer

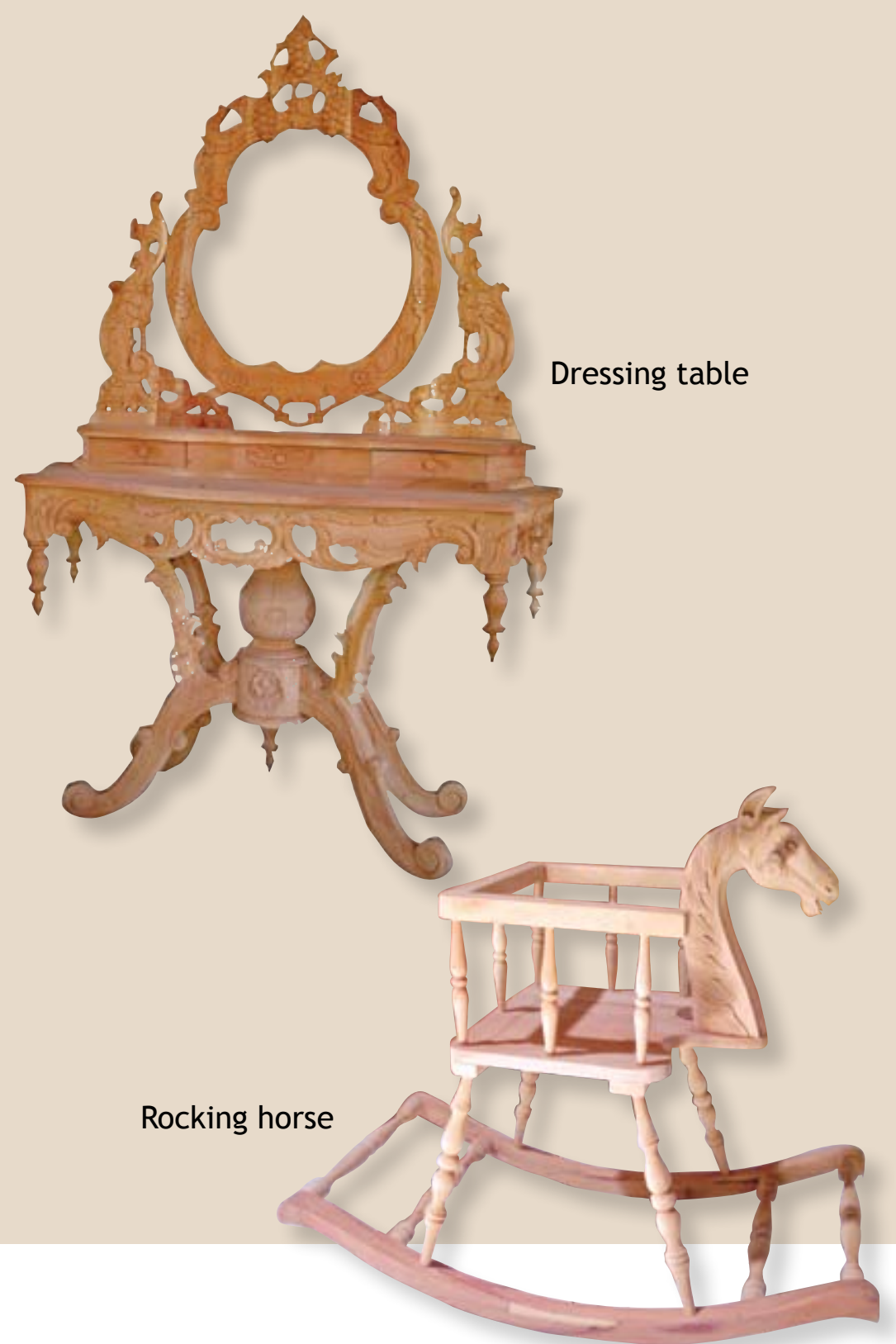

\section{Ahmad Sholikin}

Natural form furniture and craft producer

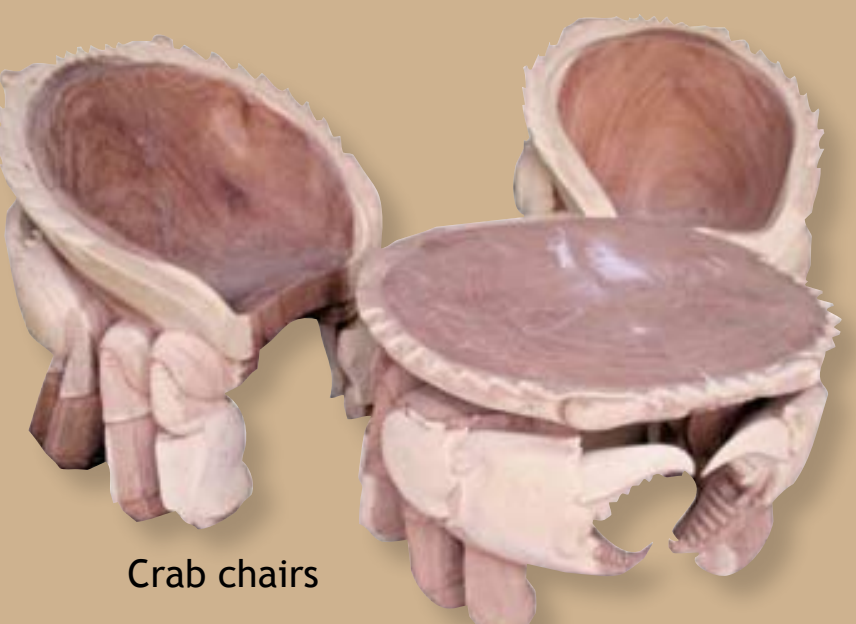

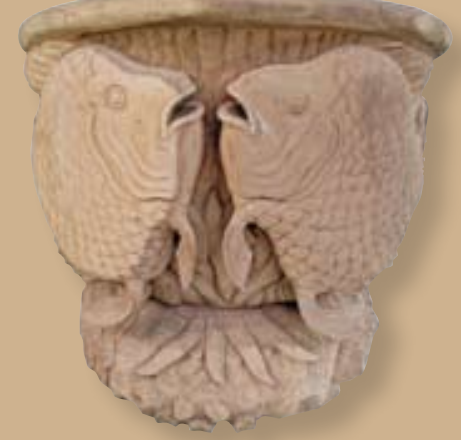

Fish chair

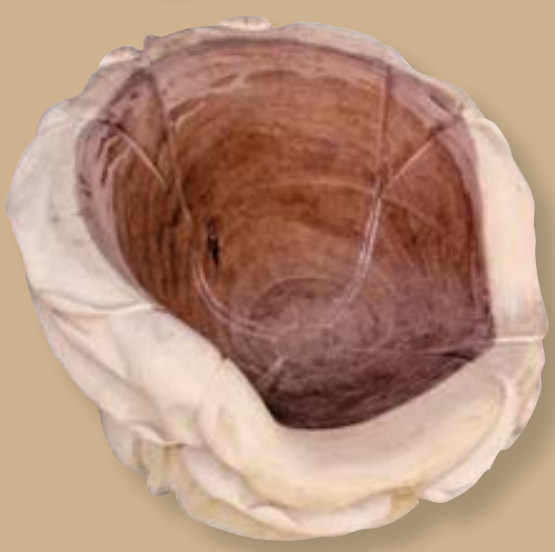

Rose petal chair 

Chapter 6

Timber trading and sawmills 


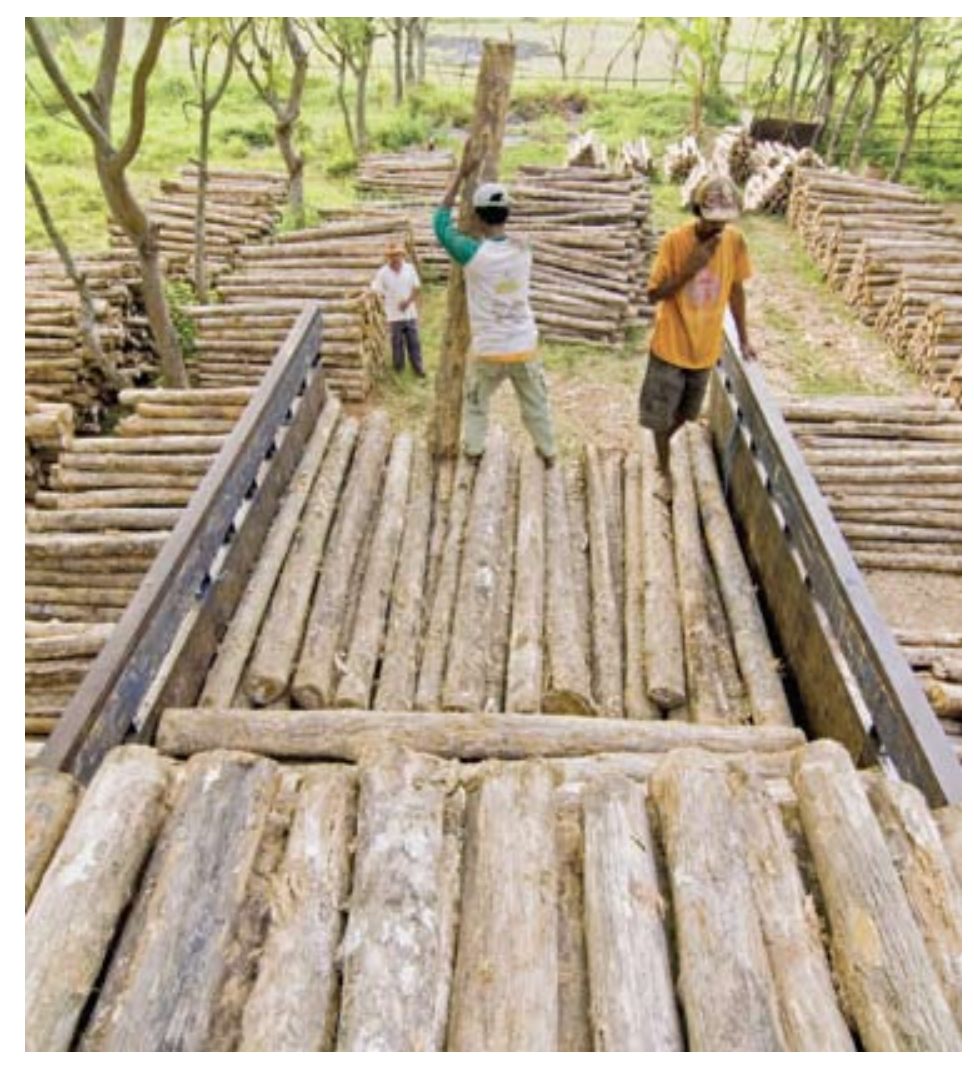

Stacks of logs at

the log yard

\section{Timber trading and sawmills}

Log traders obtain logs from community forests, the state-owned timber company Perhutani and unknown sources. Compared to 10 years ago, log traders in 2009 have greater difficulties obtaining larger diameter logs. This finding indicates a potentially alarming situation on timber availability. 


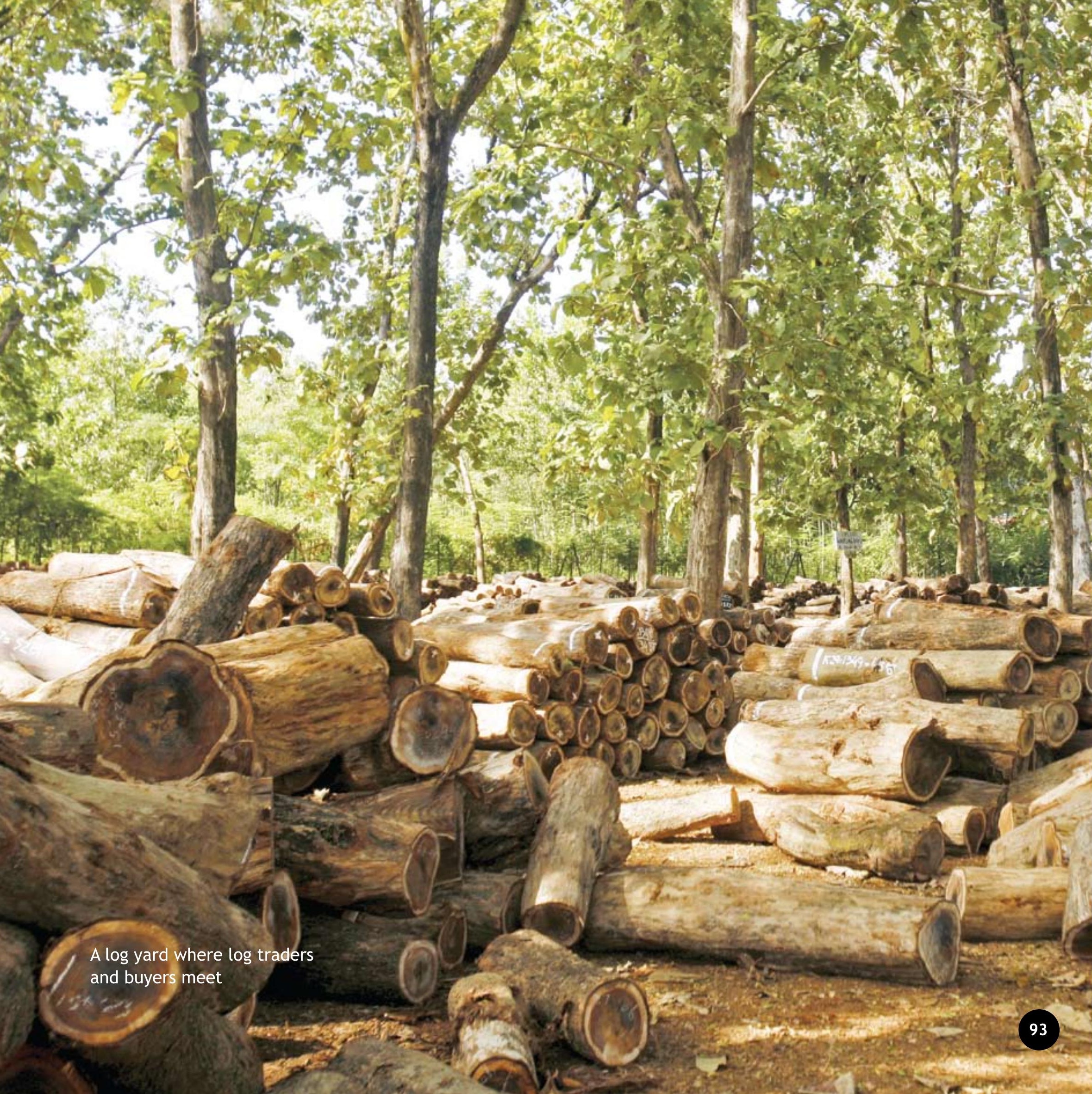





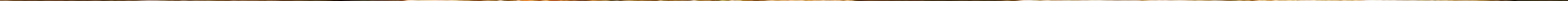




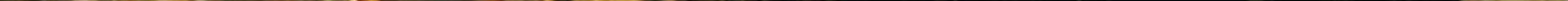




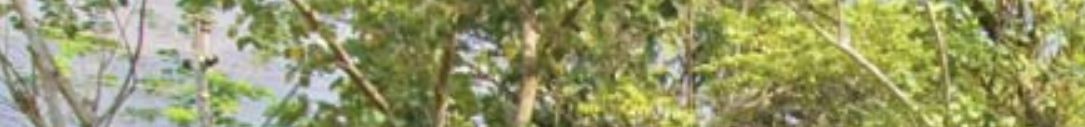

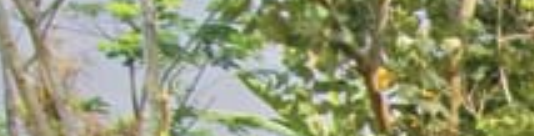

all

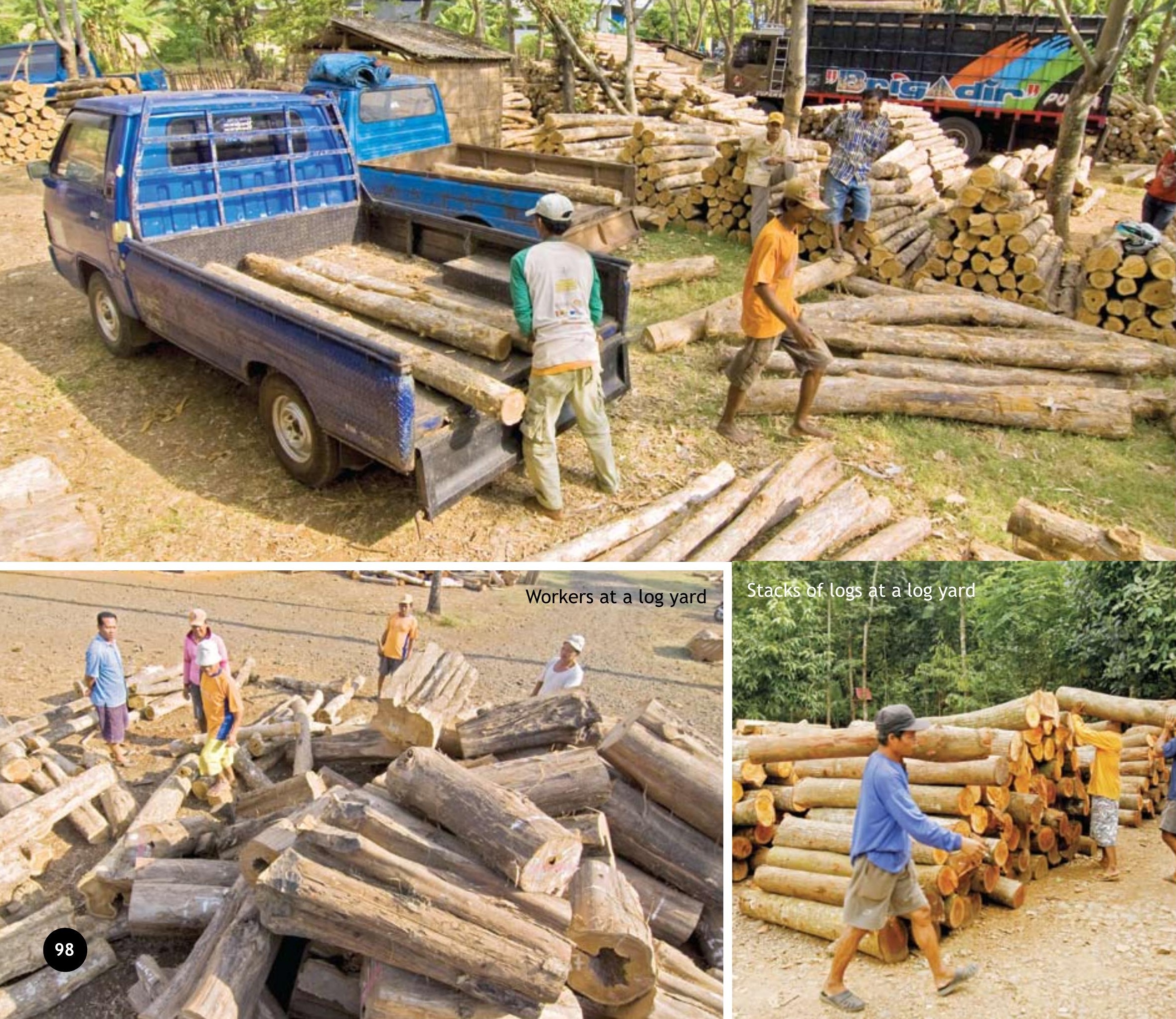




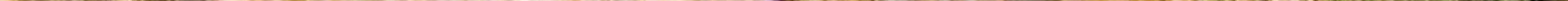




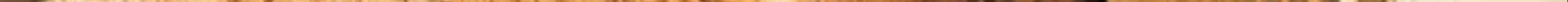




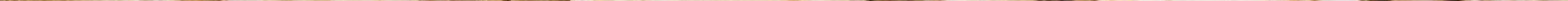




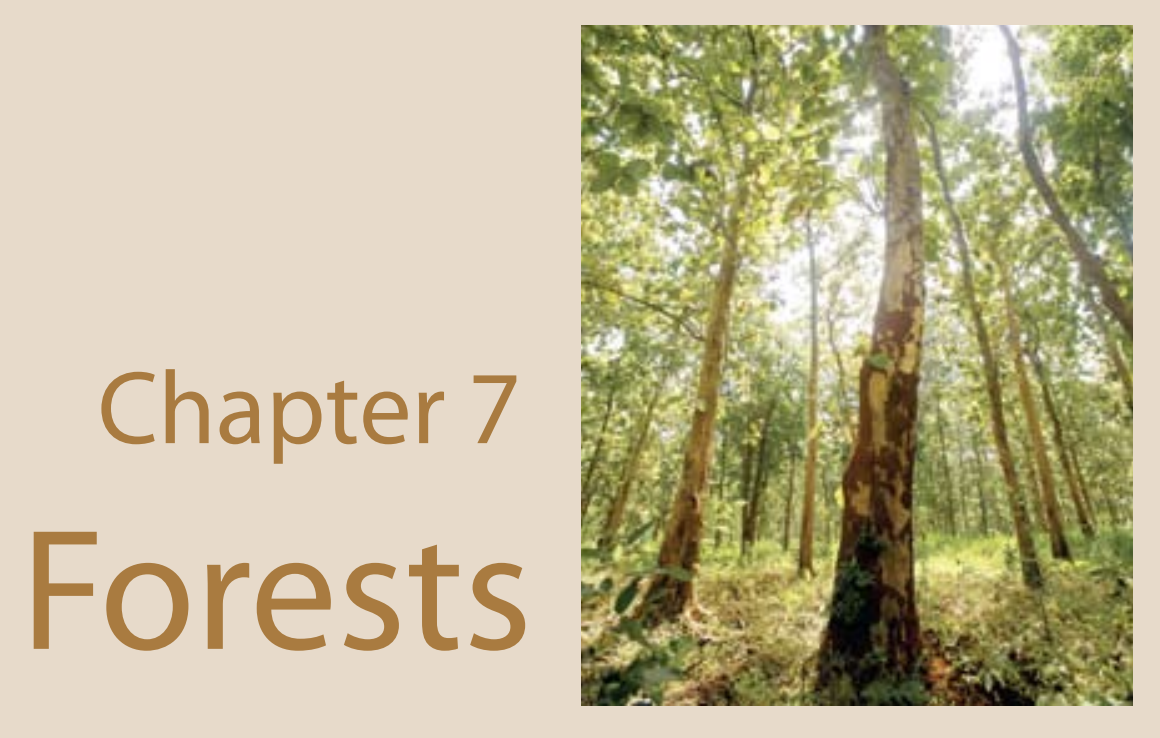




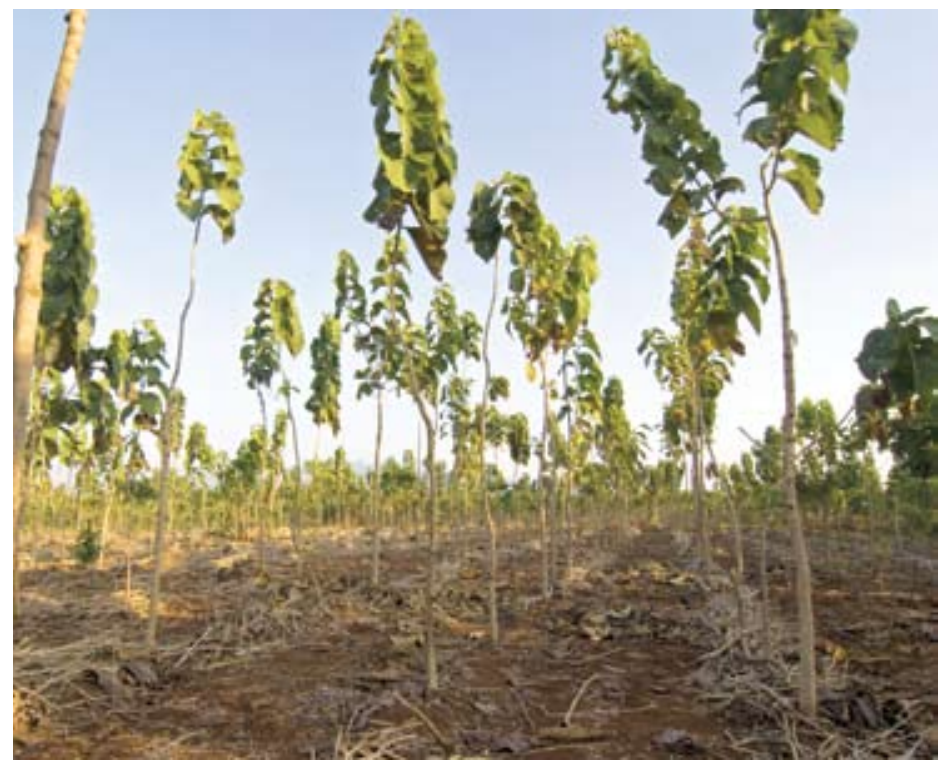

\section{Fast growing}

Perhutani teak

\section{Forests}

Teak and mahogany are the two most sought after hardwoods in international markets. Teak is the most in demand tropical hardwood due to its strength and aesthetic qualities. More than $90 \%$ of the world's teak grows in South and Southeast Asia in natural and plantation forests. Mahogany originated in natural forests in Latin America. Teak has been naturalised in Java, Indonesia, where it was introduced somewhere between 400 and 600 years ago along with mahogany. Javanese teak and mahogany plantations provide wood for many furniture manufacturers and producers in Indonesia and other parts of the world. 


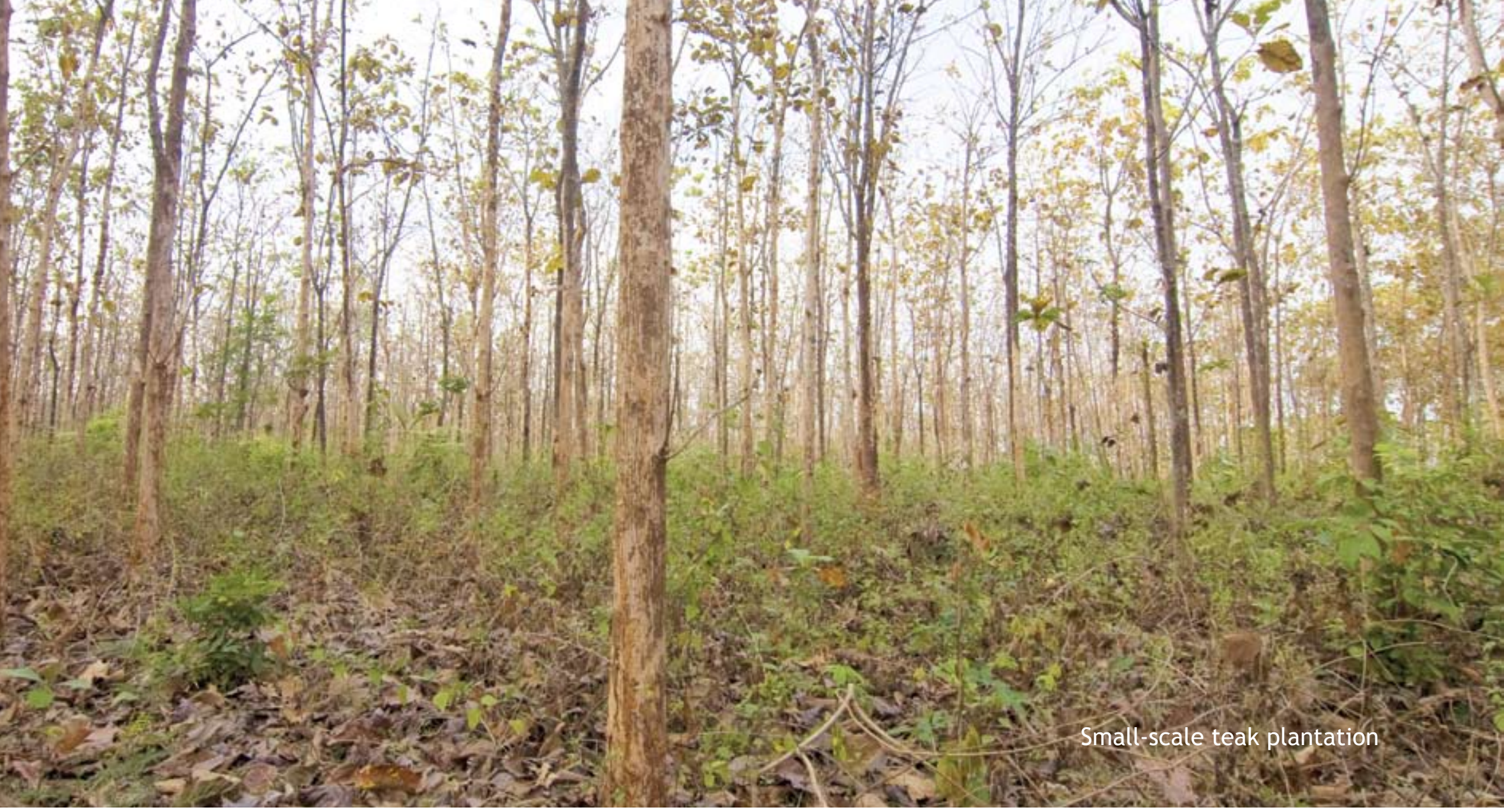

Teak and mahogany timber harvested in Java comes either from state forests or community forests. Perhutani is the state-owned, major producer of teak and mahogany. Perhutani manages about 1 million hectares of teak plantations on state lands. Hundreds of thousands of smallholders also produce teak and mahogany on community land. Small-scale harvesting is on the rise. Industry observers predict that, in future, community and smallholder forests will produce more teak and mahogany timber than Perhutani does now. The current dearth of teak to supply the furniture industry threatens the viability of this industry in Jepara. Some industries are exploring the use of other woods, including sonokeling, acacia, mangium, mango, jackfruit and durian trees as well as coconut palm stems. 


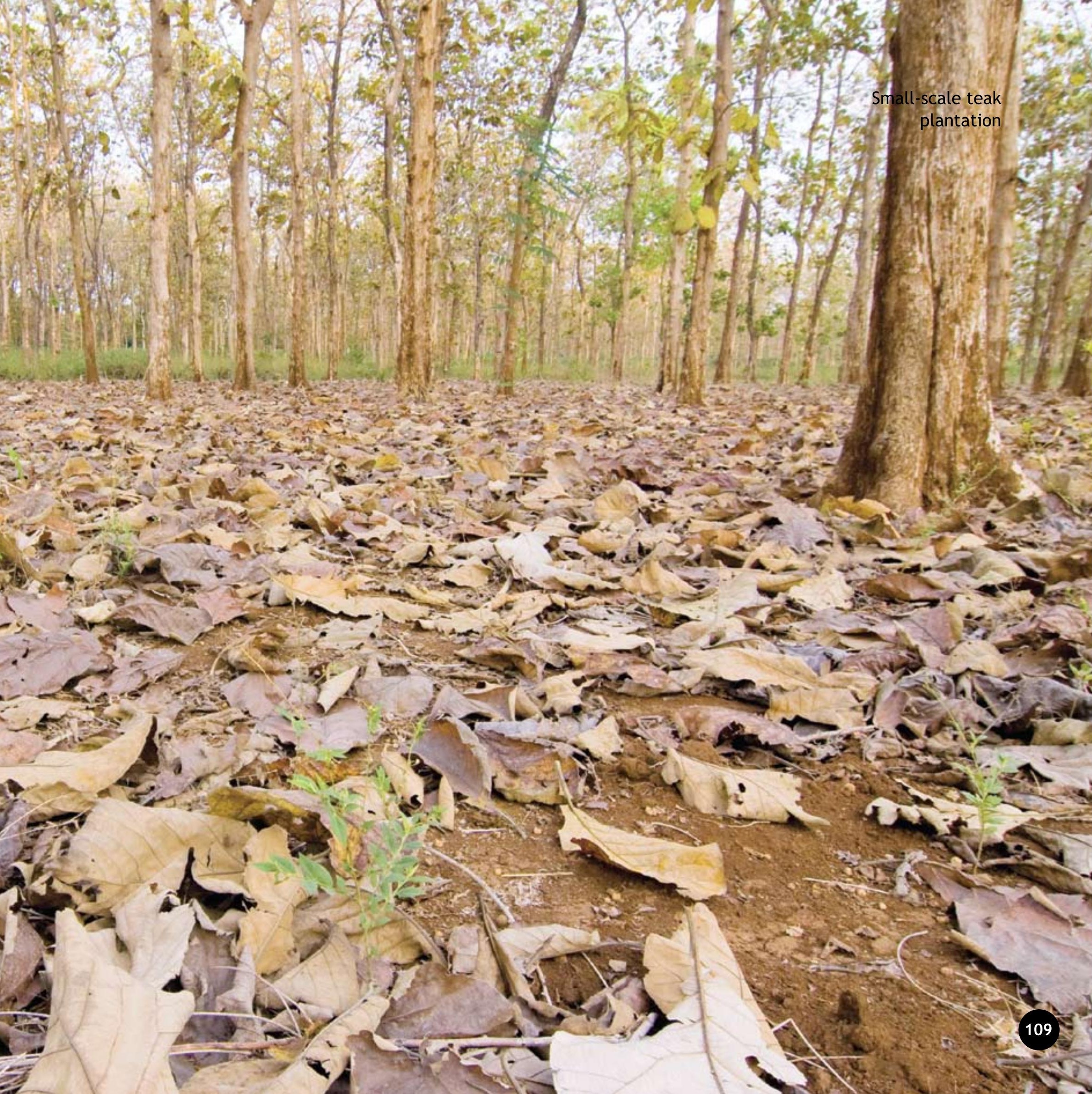




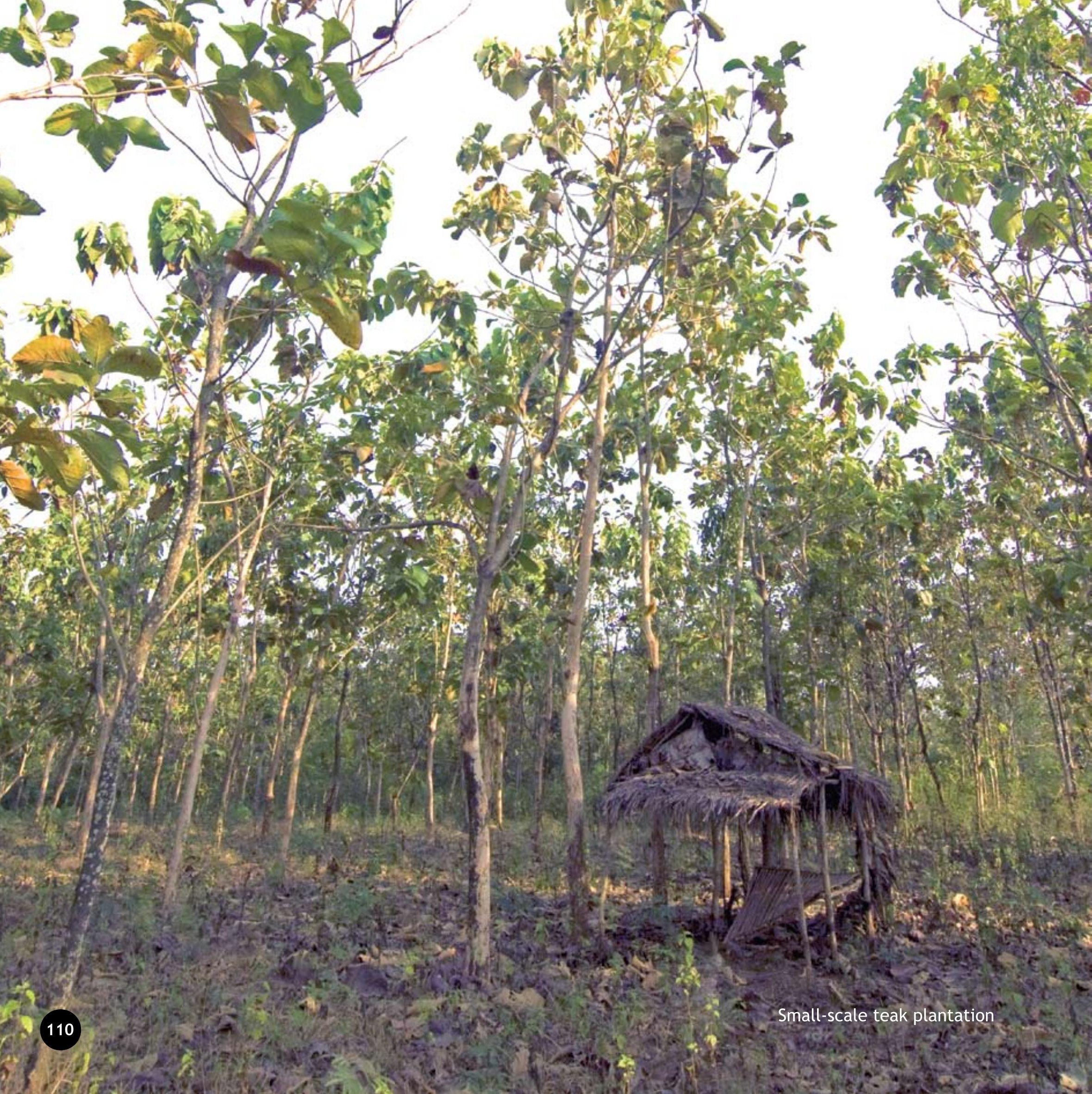




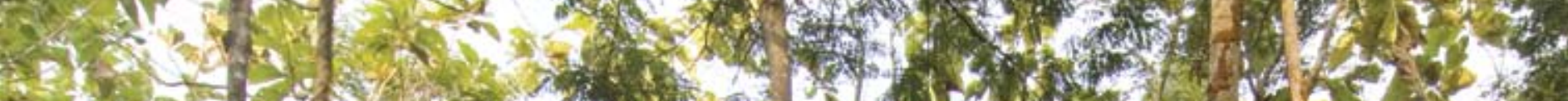

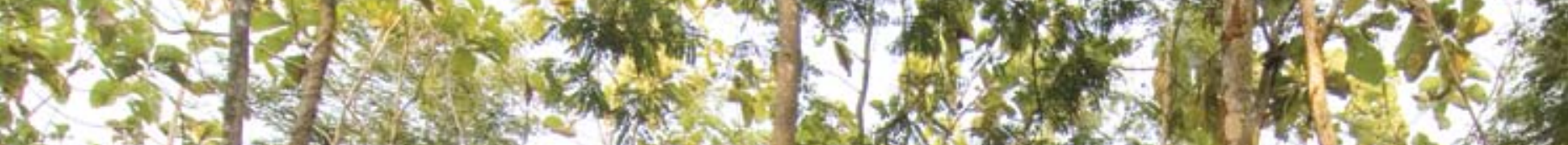
W.1.2.

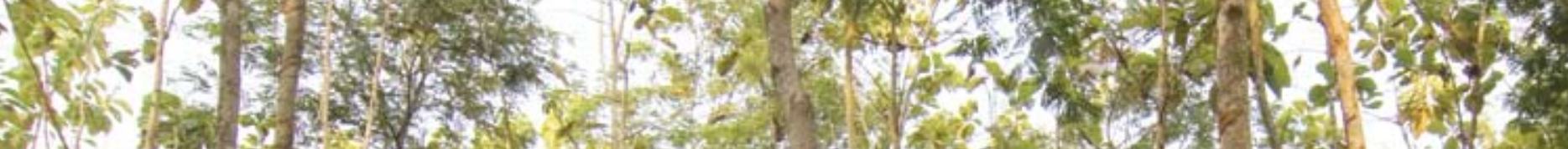

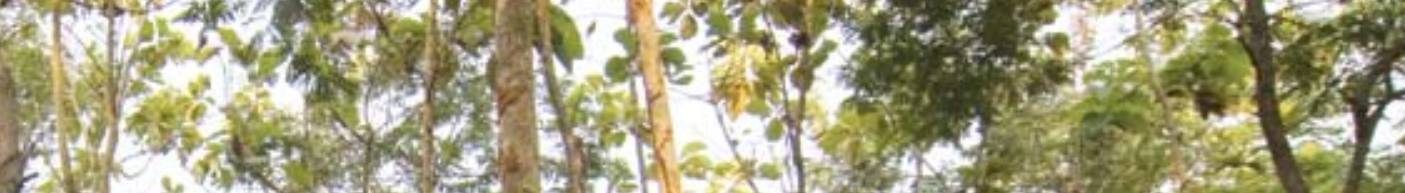

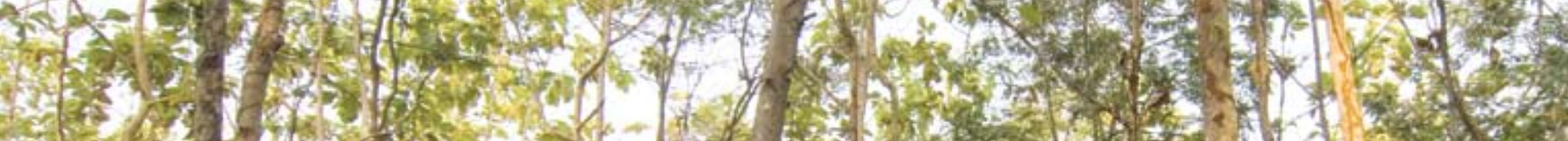

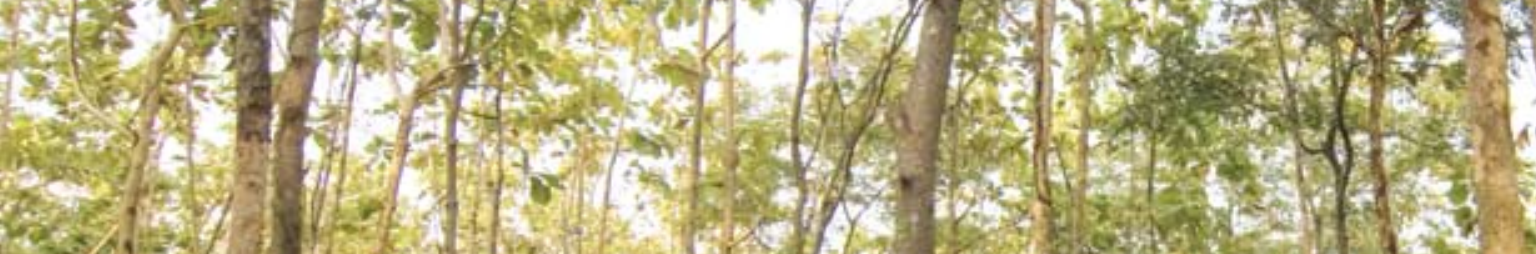
3.

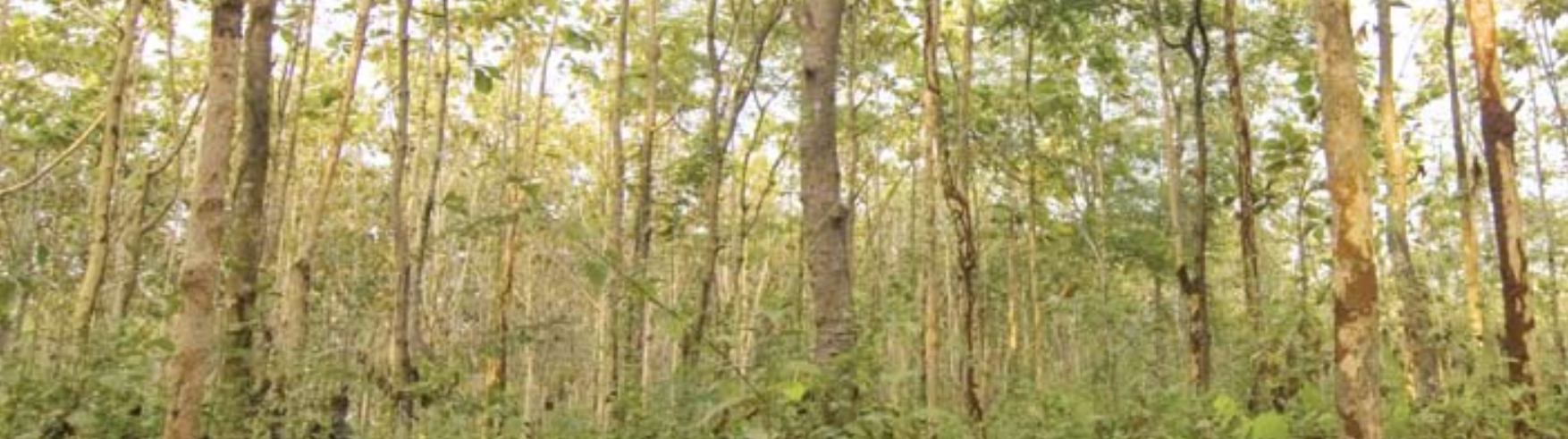

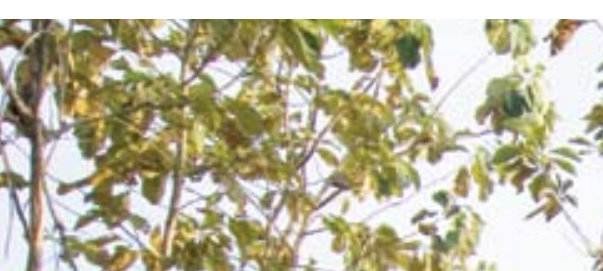
D. b. 3.1. 3. 4. 12

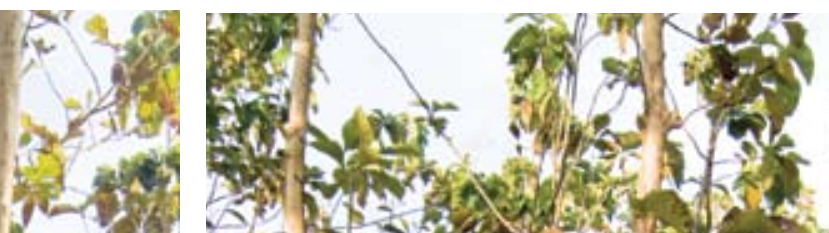

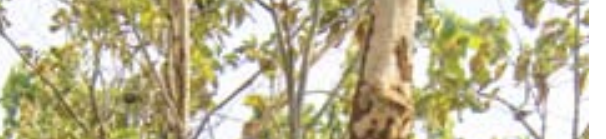
thenges (1)

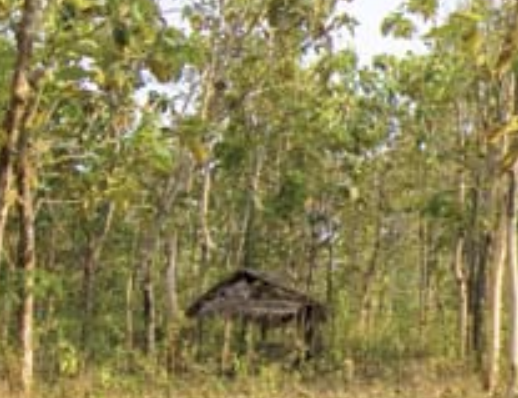

4.9

towis? $\therefore$ is

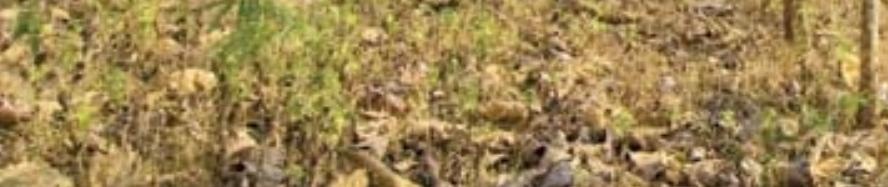

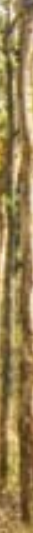

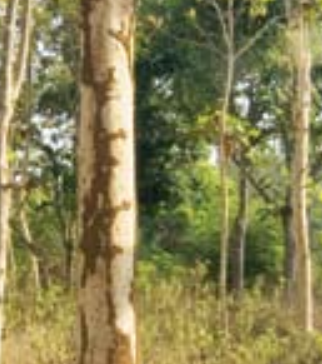

Wat

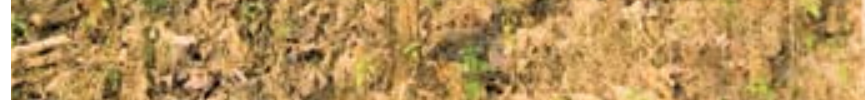

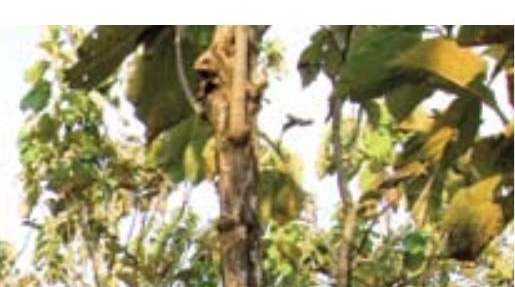
28t

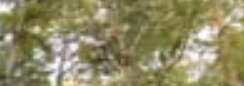

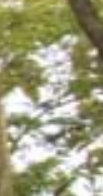
$+2$ 


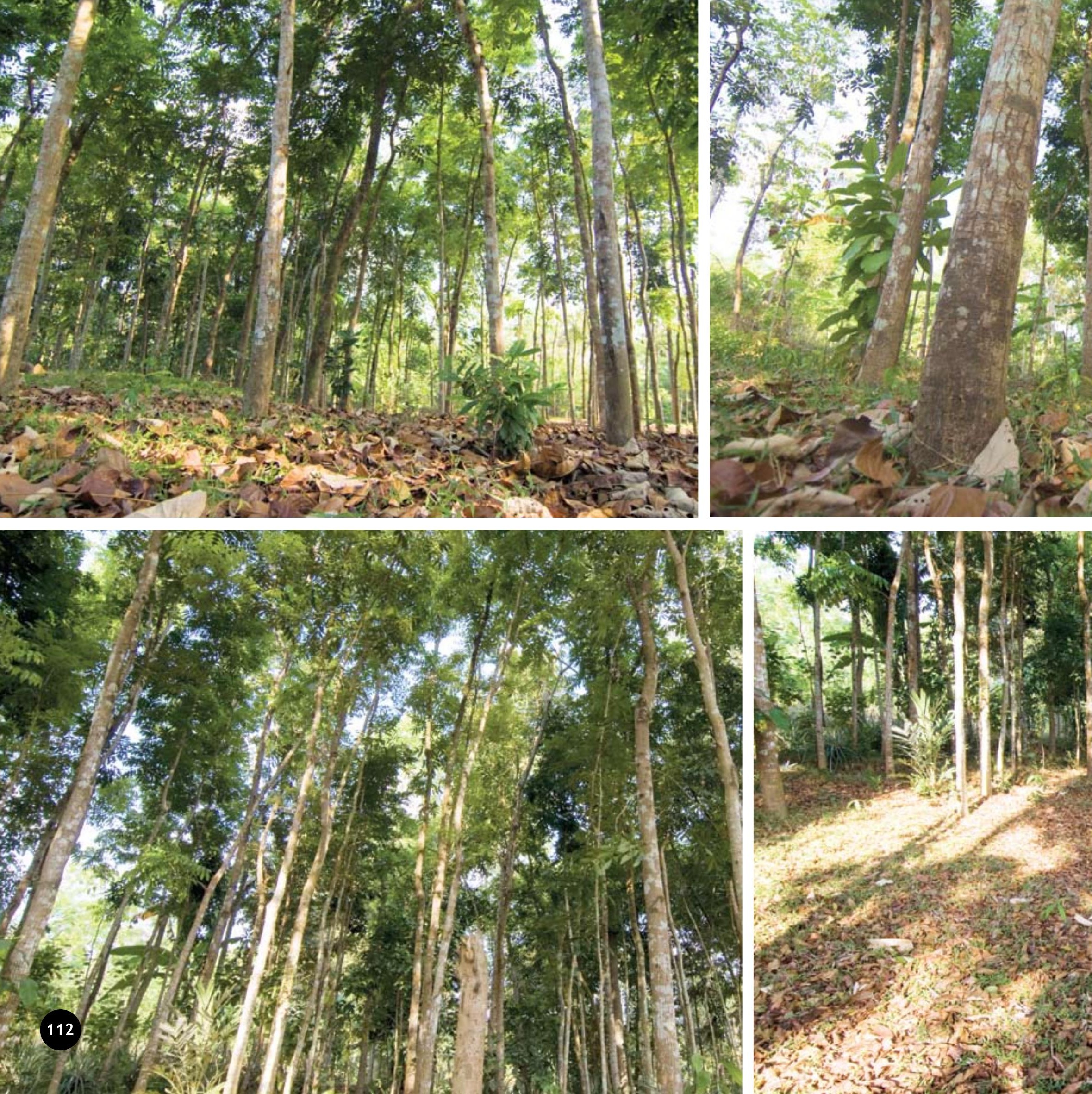




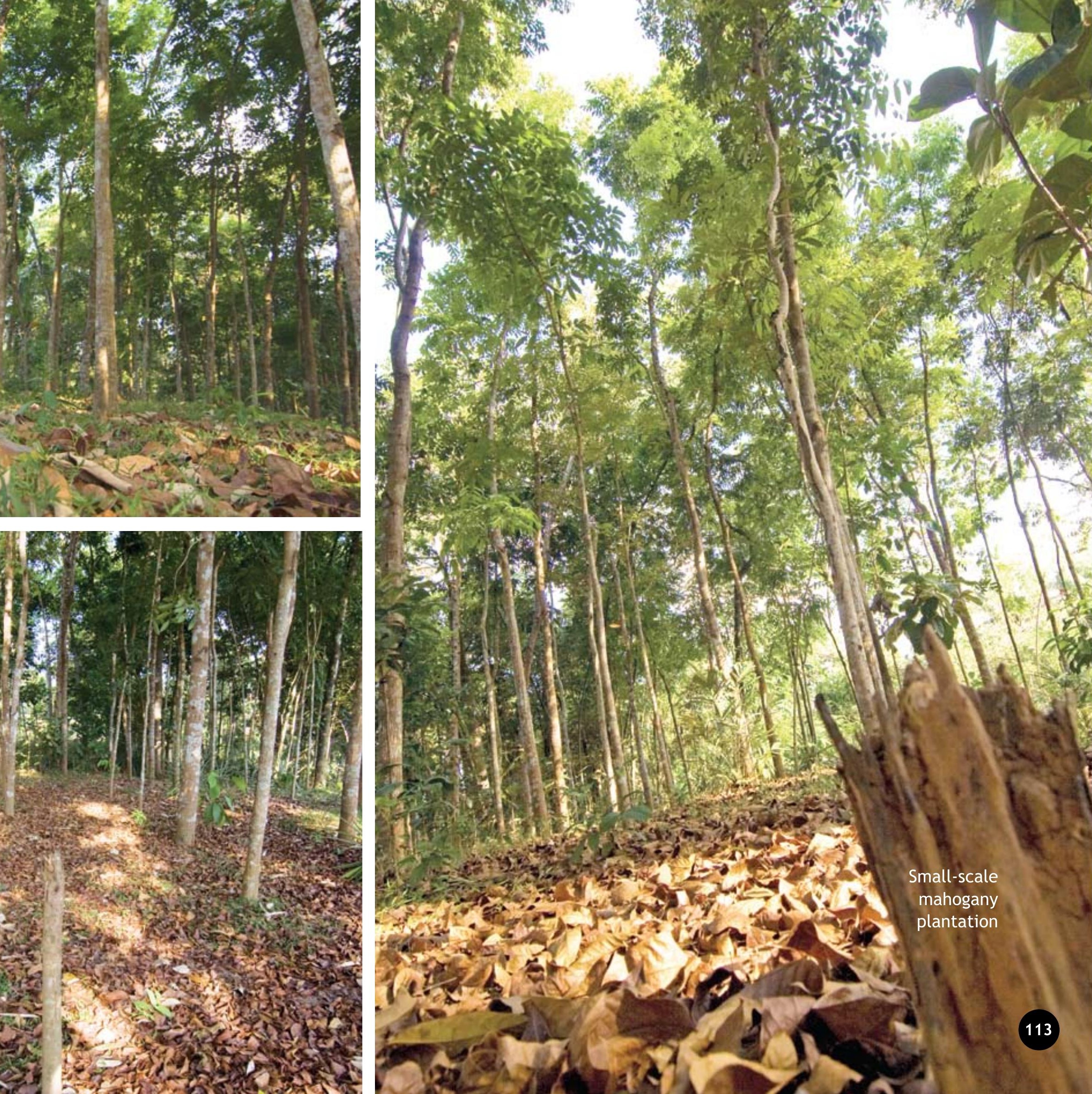




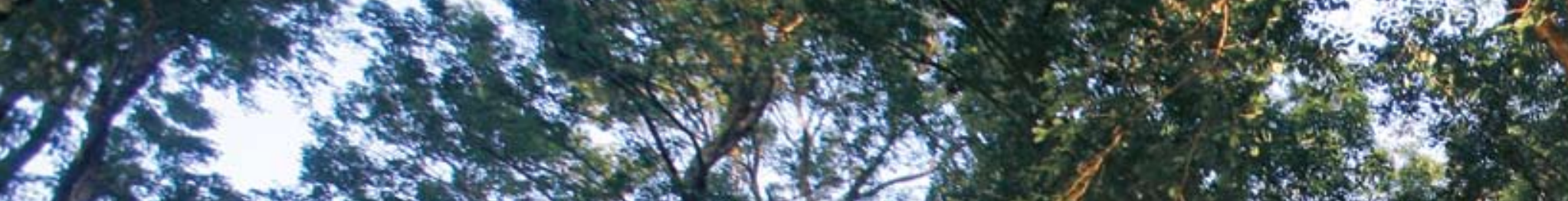

$7 \times 2$

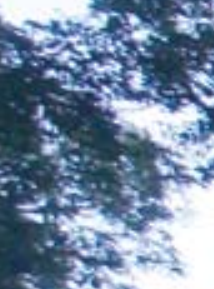

3.t.

(6)

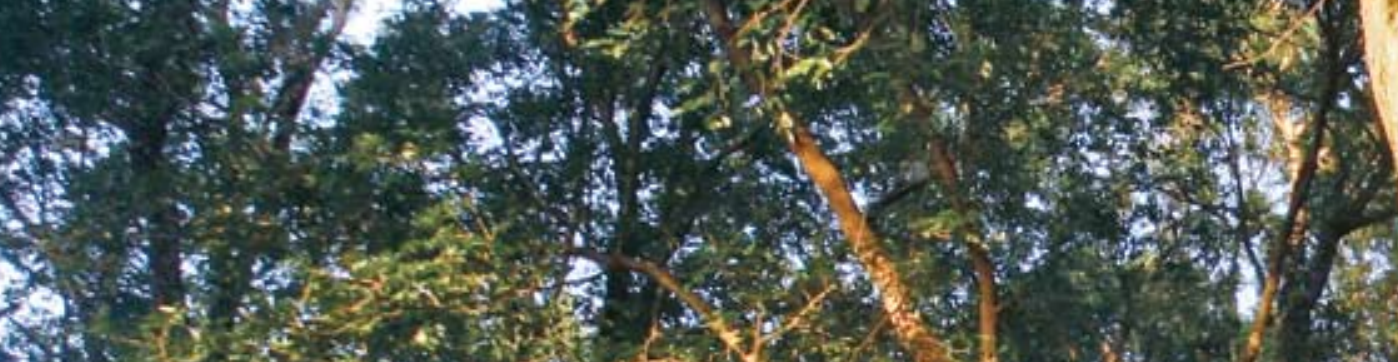

$5612=$

7.

R. r.

12.

(3)

105:

군

(1)

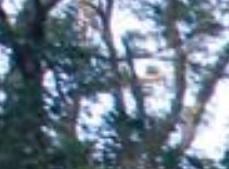

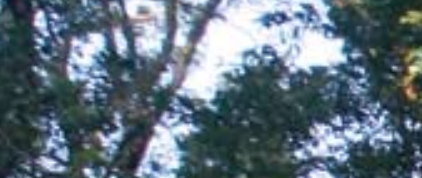

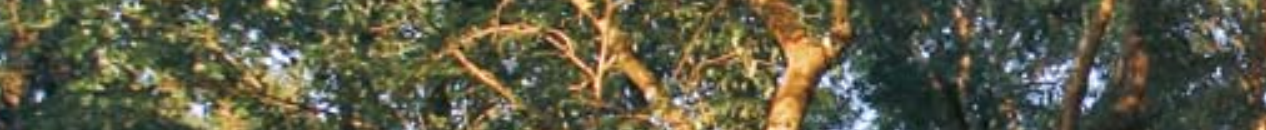

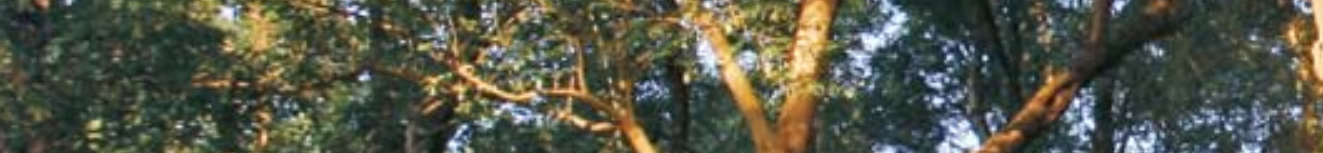

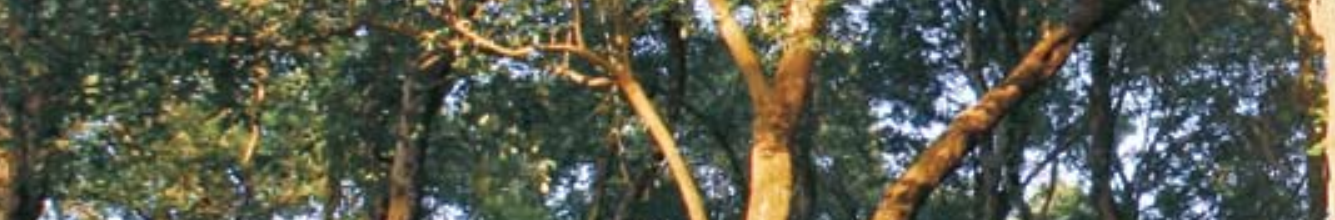

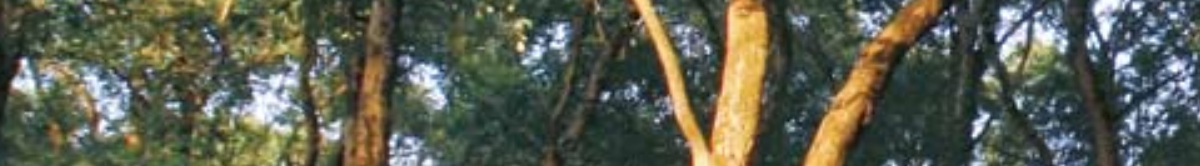

$3=2$

intis:

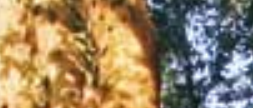
Hoy

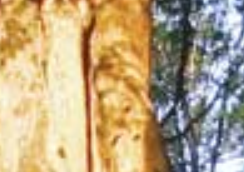

4 (1) 
(n)

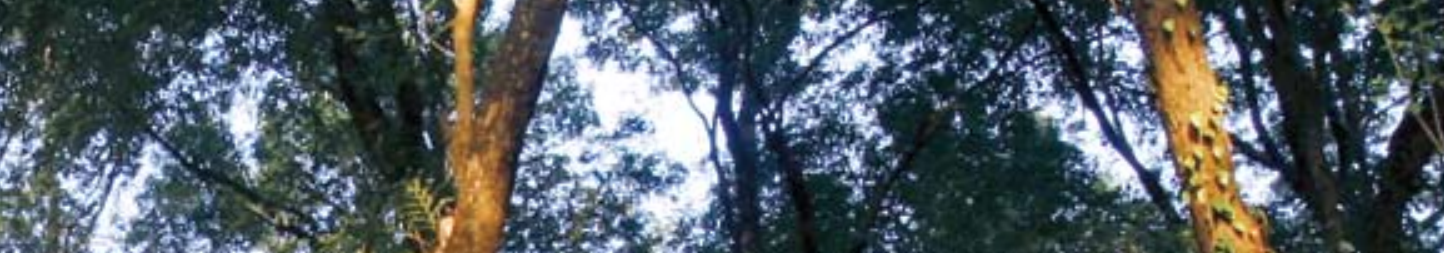

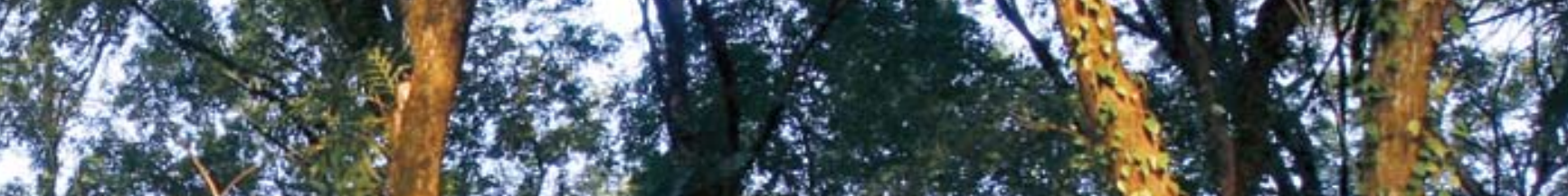

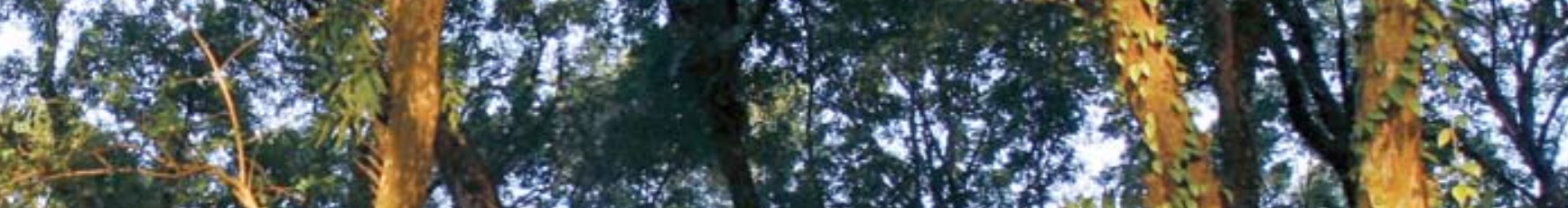

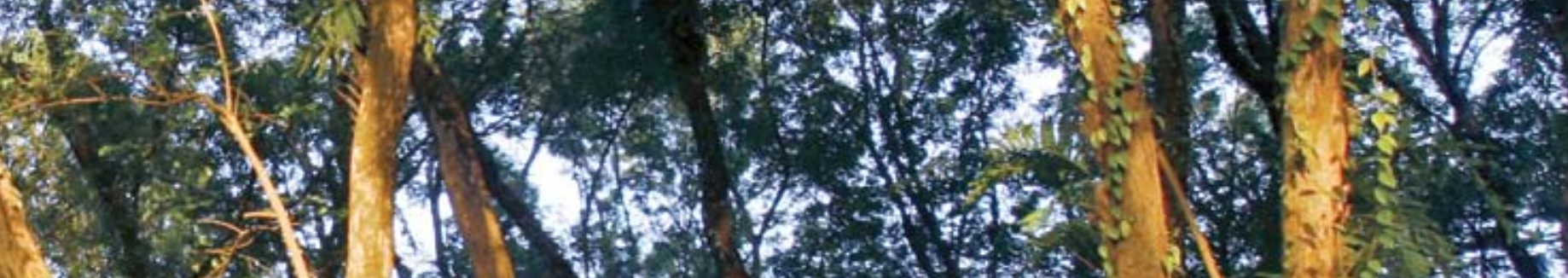
1) $19+2$

1.

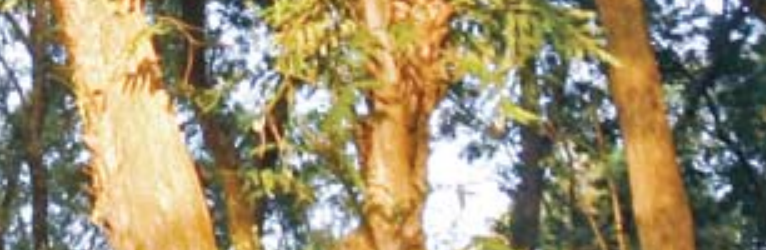
int

(1)

(1)

1.

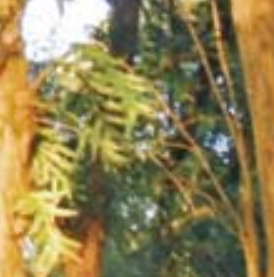

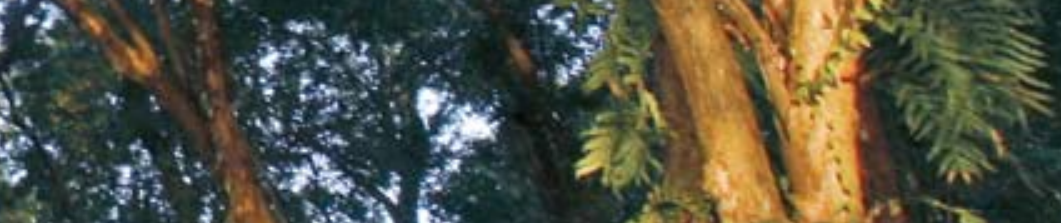

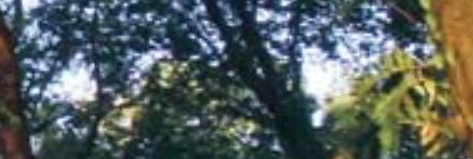

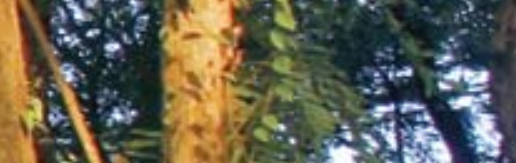

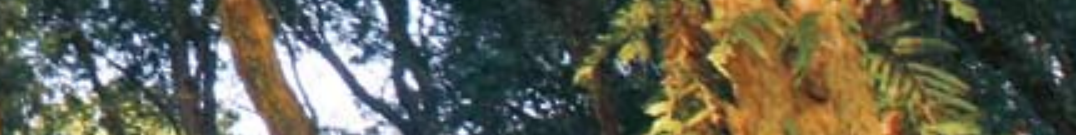
if 3 o

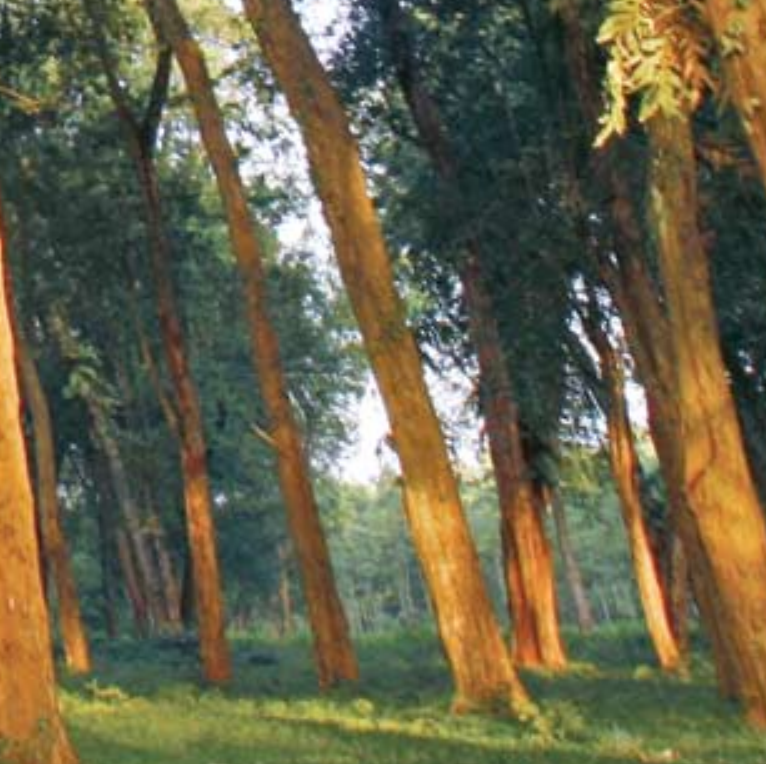

Small-scale sonokeling plantation

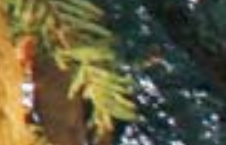

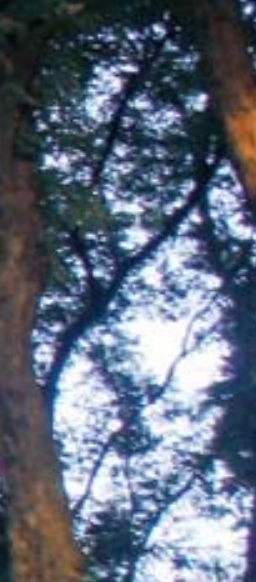

$=0$ ents

(3)

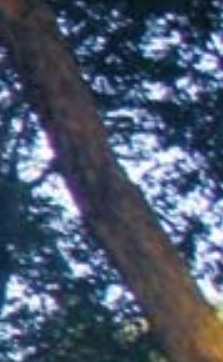

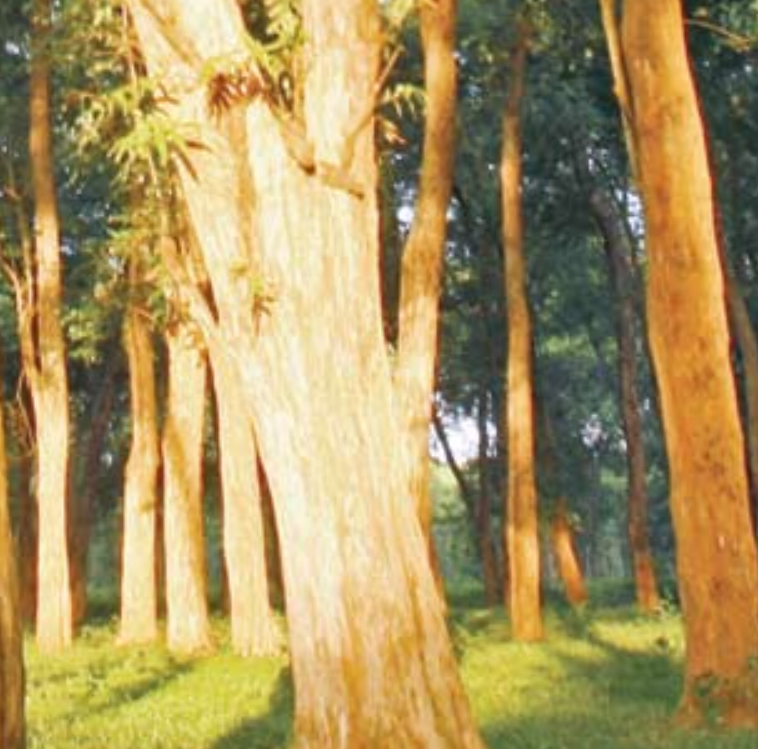

Small- 
Chapter 8

Key messages

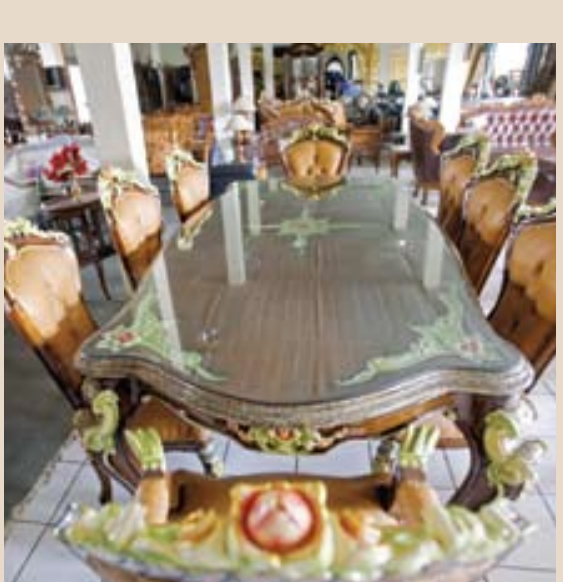




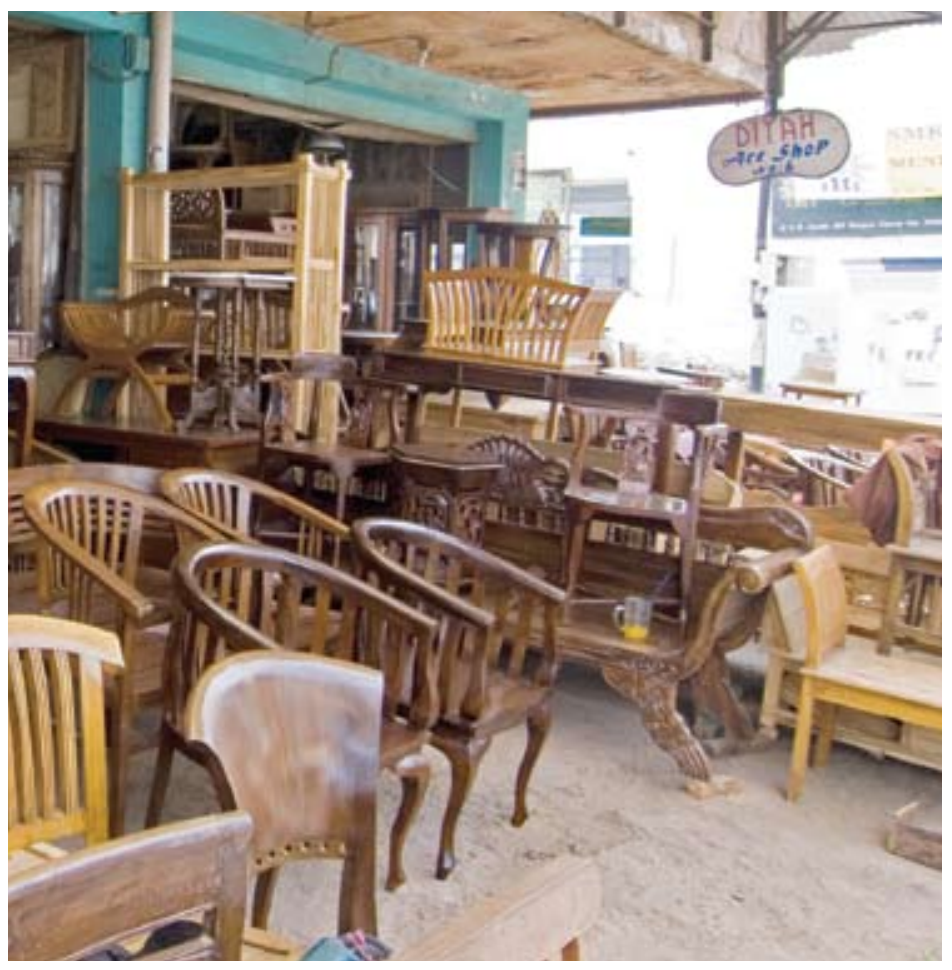

1. Many people make a living through the small-scale furniture industry.

2. A furniture industry that is culturally rooted stands a better chance of survival.

3. Jepara is a world carving and learning centre with unique culture, history and unlimited potential for creativity.

4. Action research in which understanding and changing behaviour occur at the same time is needed to improve small-scale producers' place in the industry.

5. Good governance within the value chain will provide better bargaining power, market access and wood access for small-scale producers. 
6. Government intervention is needed to improve small-scale producers.

7. Four promising scenarios could help improve the situation for small-scale producers:

- Collaborating more closely to the source: Small-scale producers collaborate with wood traders and tree growers.

- Moving up: Encourage small-scale producers to move up to the higher stages in the value chain. For example to function as furniture brokers, finishing companies or exporters.

- Green products: Produce certified, eco-labeled or green furniture. This requires up and down coordination between various companies in the value chain.

- Small-scale associations: Organise small enterprises locally and assist them in accessing financial institutions and markets. 


This publication comes out of a 5-year project CIFOR is implementing up to 2013 called the 'Mahogany and teak furniture: Action research to improve value chain efficiency and enhance livelihoods' project. This project-funded by the Australian Centre for International Agricultural Research—is being implemented by CIFOR in partnership with the Jepara District Government, the Jepara Multistakeholder Forum, the Forestry Research and Development Agency of Indonesia's Ministry of Forestry and the Faculty of Forestry at Bogor Agricultural University.

\section{www.cifor.cgiar.org/furniture}

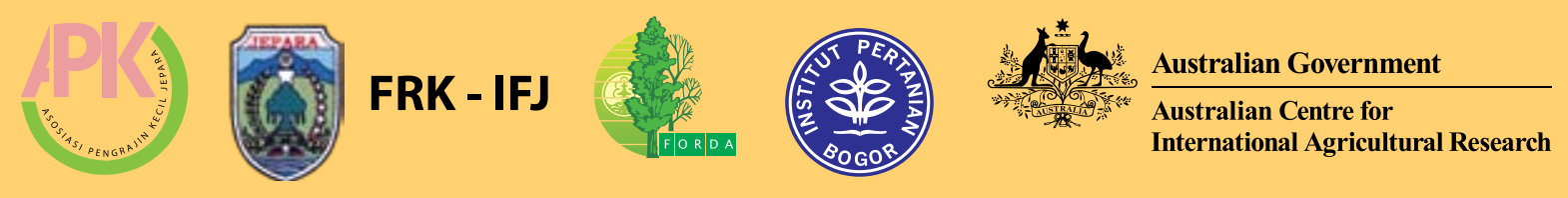

Center for International Forestry Research

CIFOR advances human wellbeing, environmental conservation and equity by conducting research to inform policies and practices that affect forests in developing countries. CIFOR is one of 15 centres within the Consultative Group on International Agricultural Research (CGIAR). CIFOR's headquarters are in Bogor, Indonesia. It also has offices in Asia, Africa and South America. 